Florida International University FIU Digital Commons

$11-10-2010$

\title{
Life-cycle cost study of ground source heat pumps in hot humid climate zone
}

Cetin Canbek

Florida International University

DOI: $10.25148 /$ etd.FI14052556

Follow this and additional works at: https://digitalcommons.fiu.edu/etd

Part of the Construction Engineering and Management Commons

\section{Recommended Citation}

Canbek, Cetin, "Life-cycle cost study of ground source heat pumps in hot humid climate zone" (2010). FIU Electronic Theses and Dissertations. 1992.

https://digitalcommons.fiu.edu/etd/1992

This work is brought to you for free and open access by the University Graduate School at FIU Digital Commons. It has been accepted for inclusion in FIU Electronic Theses and Dissertations by an authorized administrator of FIU Digital Commons. For more information, please contact dcc@fiu.edu. 
FLORIDA INTERNATIONAL UNIVERSITY

Miami, Florida

LIFE-CYCLE COST STUDY OF GROUND SOURCE HEAT PUMPS IN HOT HUMID CLIMATE ZONE

A thesis submitted in partial fulfillment of the requirements for the degree of

MASTER OF SCIENCE

in

CONSTRUCTION MANAGEMENT

by

Cetin Canbek

2010 
To: Dean Amir Mirmiran

College of Engineering and Computing

This thesis, written by Cetin Canbek, and entitled Life-Cycle Cost Study of Ground Source Heat Pumps in Hot Humid Climate Zone, having been approved in respect to style and intellectual content, is referred to you for judgment.

We have read this thesis and recommend that it be approved.

Irtishad U. Ahmad

Mehmet Emre Bayraktar

Yimin Zhu, Major Professor

Date of Defense: November 10, 2010

The thesis of Cetin Canbek is approved.

Dean Amir Mirmiran
College of Engineering and Computing

Florida International University, 2010 


\section{DEDICATION}

I dedicate this thesis to anam, babam, kardesim. 


\section{ACKNOWLEDGMENTS}

Firstly, I would like to express my gratitude to Dr. Zhu for his encouragement and guidance throughout my studies. Working under his supervision was truly a privilege and a source of inspiration for me.

I am grateful to my committee members Dr. Ahmad and Dr. Bayraktar their sincere support.

I would like to thank my parents. Also I thank my dearest friends, Kerem, Engin, Bulent and Merve for continuously reminding me that I am never alone. I know that these years that we live physically away will only strengthen our friendship. 


\section{ABSTRACT OF THE THESIS \\ LIFE-CYCLE COST STUDY OF GROUND SOURCE HEAT PUMPS IN HOT \\ HUMID CLIMATE ZONE}

by

Cetin Canbek

Florida International University, 2010

Miami, Florida

Professor Yimin Zhu, Major Professor

Ground source heat pump (GSHP) systems are gaining recognition as a cost effective and green heating, ventilating and air conditioning (HVAC) alternative in the United States. Still, this technology is not highly utilized due to factors such as high initial investment, lack of confidence and uncertainties in cost items.

This study focuses on the reflection of the variations in cost items on the feasibility and life-cycle cost of a typical GSHP system. For this purpose, life-cycle costs were calculated for a typical GSHP system and cost data was gathered for several projects. Possible variations on cost variables are defined. Then, the effect of these variations on life cycle cost is analyzed on a comparative basis with a conventional system. It was concluded that the GSHP systems may not be economically favorable over a conventional HVAC systems without current incentives in hot and humid climate regions. 
1 - Introduction 1

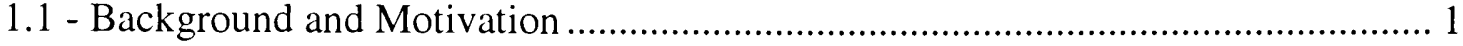

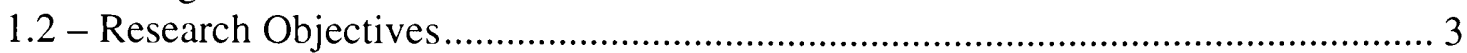

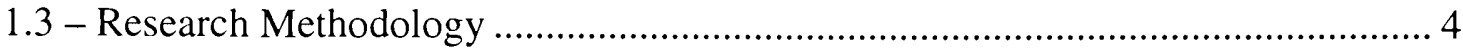

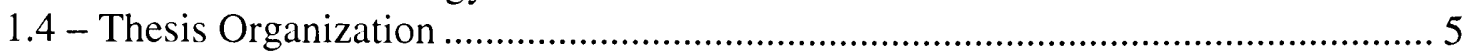

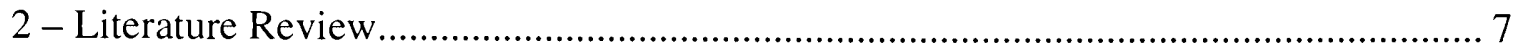

2.1 - Cost Aspects of Ground Source Heat Pump Systems.......................................... 7

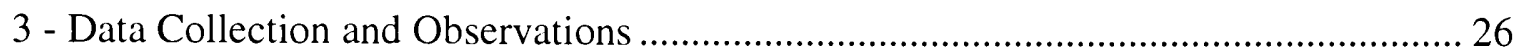

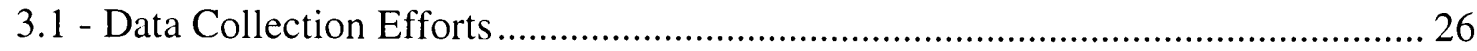

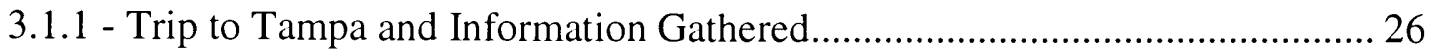

3.1.2 - Trip to Pensacola and Information Gathered............................................. 33

3.2 - General Observations about GSHP Systems ................................................... 42

4- Life-Cycle Cost Analysis and Sensitivity Analysis.................................................... 45

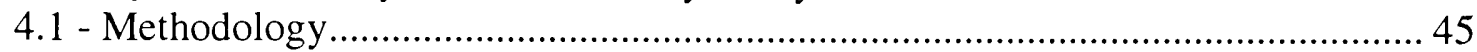

4.2 - General Parameters for Life-Cycle Cost Study ................................................. 47

4.3 - Life-Cycle Cost Analysis Items for GSHP System ............................................... 49

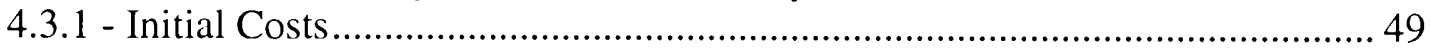

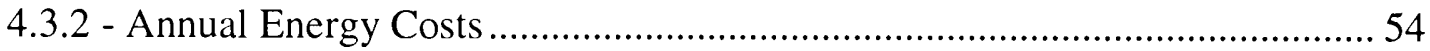

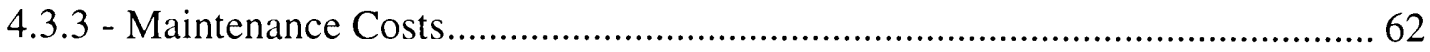

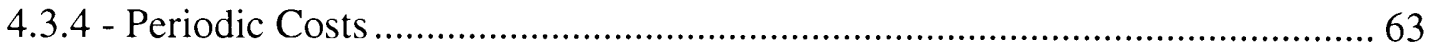

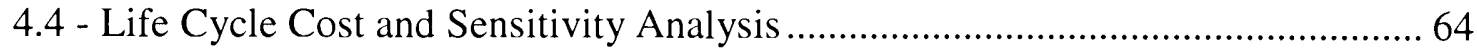

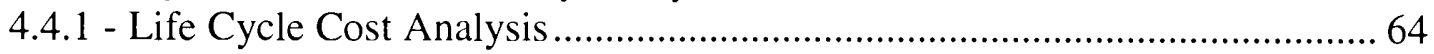

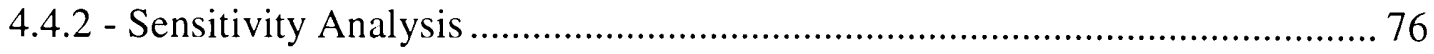

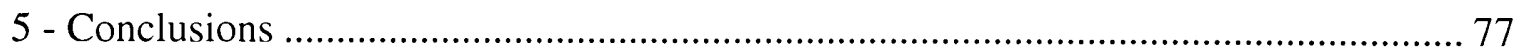

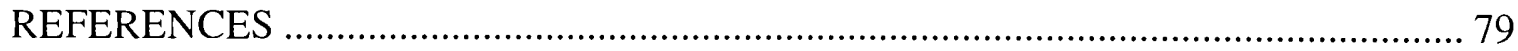

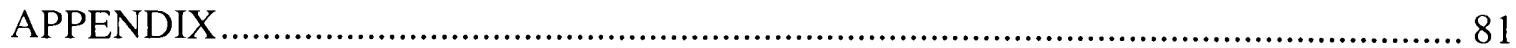




\section{LIST OF TABLES}

TABLE

PAGE

Table 1 - Life Cycle Cost Estimates of the Three Systems Considered

(Chiasson, 2006)

Table 2 - Life-Cycle Cost Estimates of the Two Systems Considered

(Chiasson, 2006)

Table 3 - Life-Cycle Cost Breakdown for the GSHP system considered

(Chiasson, 2006)

Table 4 - GSHP System Capital Costs by Building and Earth Connection Types

Table 5 - Capital Costs of Conventional HVAC Systems

Table 6 - Energy Consumption data of GSHP and conventional GSHP systems (Moore, 1999)

Table 7 - Heat Pump Shipments between 1994 and 1997 (Holihan, 1998).

Table 8 - General information about the building and GSHP system of First

Residential Building. 29

Table 9 - General information about the building and GSHP system of Second Residential Building. 32

Table 10 - Initial costs for vertical closed loop systems 50

Table 11 - Initial costs for horizontal closed loop systems 52

Table 12 - Initial costs for open loop systems 53

Table 13 - Assembly Costs used for Conventional HVAC System. 54

Table 14 - Life Cycle Costs and Items Considered for two systems for one ton capacity 65 


\section{LIST OF FIGURES}

FIGURE

PAGE

Figure 1- Cost Breakdown of 3 ton GSHP systems (Kavanaugh et al., 1995) ................. 16

Figure 2 - Costs for two different systems in different locations (Fredin, 2009) ............. 21

Figure 3 - Annual operating costs for two different systems in different locations

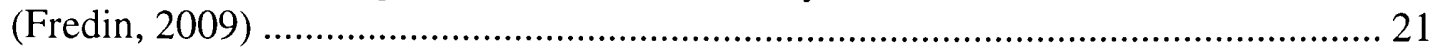

Figure 4 - Payback periods of GSHP systems compared to NGAC systems in

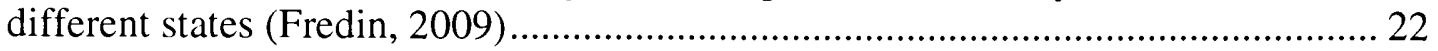

Figure 5- Cost Breakdown of First Residential Building ............................................. 27

Figure 6 - The heat pump unit installed in the garage area.......................................... 28

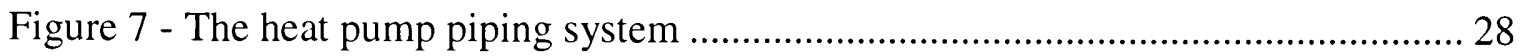

Figure 8 - Discharge and suction wells; green paining as an aesthetic idea.................... 30

Figure 9 - Cost Breakdown of Second Residential Building ....................................... 31

Figure 10 - The area that slinky loops were installed beneath it 20 years ago .................. 31

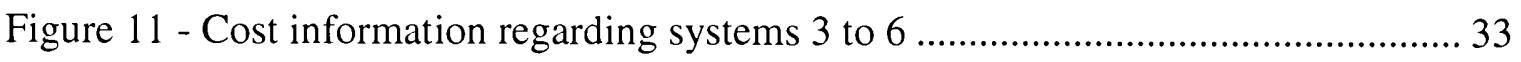

Figure 12 - Cost Breakdown of Springhill Suites HVAC System................................... 35

Figure 13 - Springhill Suites Indoor heat pump unit ................................................... 35

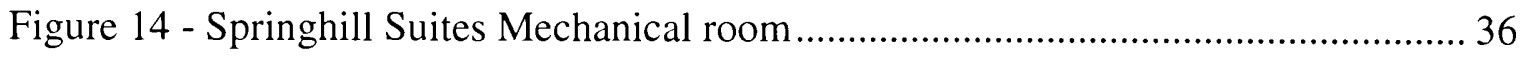

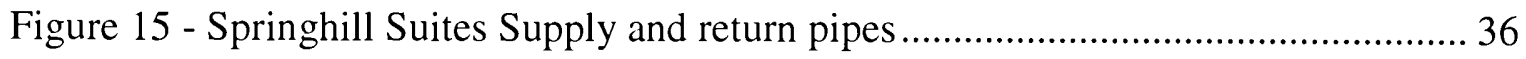

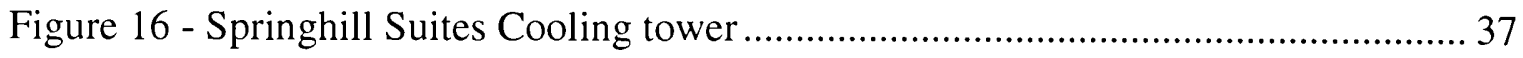

Figure 17 - Cost Breakdown of Grand Marlin Restaurant HVAC System........................ 38

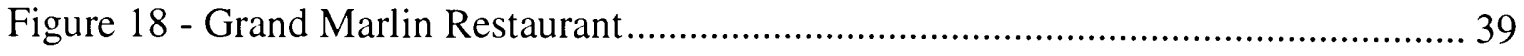

Figure 19 - Grand Marlin Restaurant-Supply and return pipes ..................................... 39

Figure 20 - Cost Breakdown of Rodney Rich Building HVAC System ......................... 40 
Figure 21 - Rodney Rich building 1 ton unit. 41

Figure 22 - Rodney Rich building Main loop pumps .................................................. 41

Figure 23 - Rodney Rich building-Supply and return pipes ......................................... 42

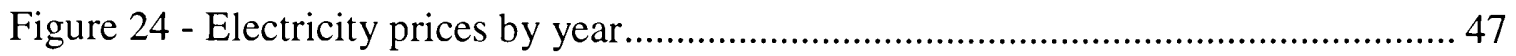

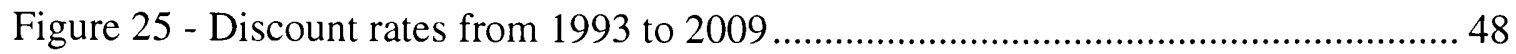

Figure 26 - Construction Cost Index from 1980 to 2010 .................................................. 49

Figure 27 - Cost of vertical closed loop per ton of system capacity............................. 51

Figure 28 - 3D Geometry of the house used as a basis for analysis ................................ 55

Figure 29 - Monthly heating and cooling loads on the system ...................................... 57

Figure 30 - Monthly electricity consumptions of the two systems considered in

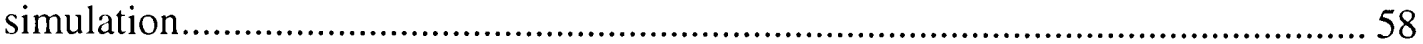

Figure 31 - Annual electricity costs for the two systems considered in simulation ......... 59

Figure 32 - Electricity consumptions for two systems considered .................................6 60

Figure 33 - Total electricity consumption for units with GSHP and conventional

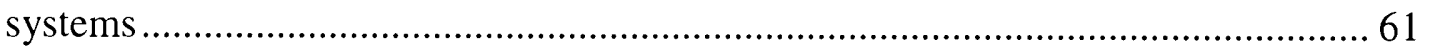

Figure 34 - Electricity costs of GSHP and conventional HVAC systems for residential units

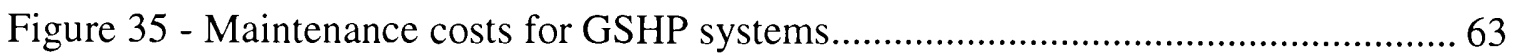

Figure 36 - Life-cycle cost calculations of the two alternatives per ton of capacity ........ 65

Figure 37 - Comparative life-cycle cost calculations for residential unit 1 ......................66 66

Figure 38 - Comparative life-cycle cost calculations for residential unit 2 ....................6 67

Figure 39 - Comparative life-cycle cost calculations for residential unit $3 \ldots \ldots \ldots \ldots \ldots \ldots \ldots . . .67$

Figure 40 - Comparative life-cycle cost calculations for residential unit 4 .....................6 68

Figure 41 - Comparative life-cycle cost calculations for Rodney Rich Building............. 69 


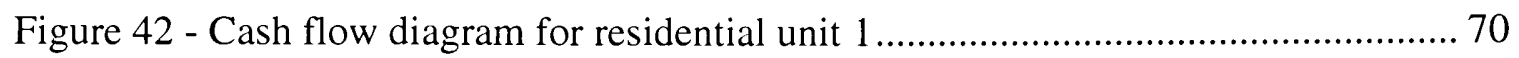

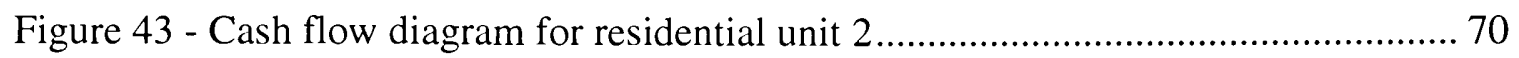

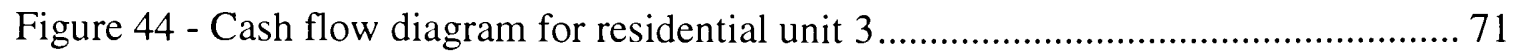

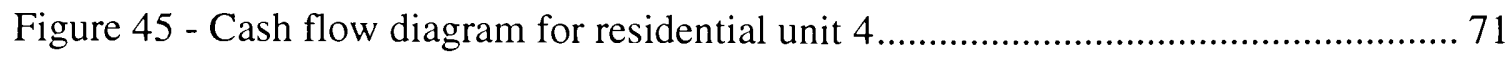

Figure 46 - Cash flow diagram for Rodney Rich Building............................................ 72

Figure 47 - Life-cycle cost calculations for residential unit 1 after incentives.................. 73

Figure 48 - Life-cycle cost calculations for residential unit 2 after incentives................ 74

Figure 49 - Life-cycle cost calculations for residential unit 3 after incentives.................. 74

Figure 50 - Life-cycle cost calculations for residential unit 4 after incentives.................. 75

Figure 51 - Life-cycle cost calculations for Rodney Rich Building after incentives........ 75

Figure 52 - The change in net present worth with respect to initial costs and

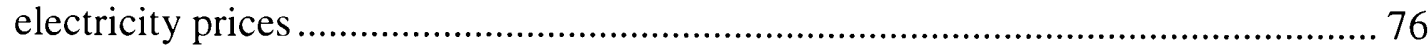




\section{1 - Introduction}

\section{1 - Background and Motivation}

A ground source heat pump (GSHP) system is a heating, ventilating and air conditioning (HVAC) alternative that utilizes the ground as a heat source or sink. Working mechanism of a GSHP is the same with the conventional HVAC systems but the medium of heat gain or dissipation is different. The temperature below earth gets steadier as the depth increases. Also, it is cooler the than outside air during hot weather, and hotter during cold weather. A GSHP system uses the earth or the water below the earth and utilizes the greater temperature difference and, in most cases, uses less energy compared to conventional HVAC systems.

GSHP systems can tentatively be divided into four according to their means of dissipating excess heat or gaining heat from the medium. These are vertical closed loop GSHP systems, horizontal closed loop GSHP systems, open loop (well) GSHP systems and surface water (pond) GSHP systems.

Vertical closed loop GSHP systems, the pipes are buried underground vertically in drilled boreholes and the heat transfer is realized through these pipes. The depth and number of the boreholes depends on the underground conditions and the system requirements. In these systems, the liquid constantly circulates between the loop and the heat pump utilizing the steady temperatures underground. These systems are preferred when there's not enough space and the vicinity of the installation site should not be 
disturbed. Pipes are installed in U-bend formation after the drilling activity is finished and then grouted or filled with earth. Later, these individual U-bend pipes are connected to main supply and return pipes. This type of systems is usually more costly due to drilling activities.

Horizontal closed loop GSHP systems are used when enough space exists and the capacity of the unit is designed to be relatively smaller. In this configuration, a trench, which is about 6 feet deep, is dug and the pipes are placed in. The pipes are either placed into the trench parallel to the ground, or in a circular (slinky) configuration. These configurations are relatively low in terms of cost as there is no drilling activity involved.

Open loop GSHP systems use the groundwater under the earth as a heat source or heat sink. Unlike the closed loop systems, the fluid doesn't circulate but taken from aquifer and disposed to the same source. A representation of an open loop system is shown in Figure 1.2. This working mechanism have been used long before the modern systems came out and still preferred when there is sufficient groundwater sources. Usually there are at least two adequately spaced wells, one being outlet and other being inlet. Also there are single well configuration, which are referred to as "standing columns well", where the water is taken and disposed to the same well.

Lastly, surface water or pond GSHP systems utilize a pond, lake or swimming pool as their heat source or sink. These systems can be used whenever there is a sufficiently large volume of water in close vicinity of the building and environmental regulations allow such usage. The piping is placed under or inside the water and the heat 
transfer fluid circulates inside the piping to dissipate or gain heat. They can be economical as there is no excavation or drilling activity involved but these systems are used seldom as there is usually no available surface water.

With the growing trend toward zero energy buildings, and increasing efforts to minimize environmental impact, GSHP systems are foreseen as an economical and green solution to heating and cooling needs for residential and commercial buildings. Many studies and reports indicate that GSHP systems are more economical than the conventional HVAC systems and prove to be cost effective in the long term. Nevertheless, the high initial costs along with some uncertainties in the industry can deter end users from this alternative. Therefore, a detailed life-cycle cost analysis methodology, which takes into consideration the variability of parameters that affects the cost, is needed for further acknowledgement and wider usage of these systems. By using the current data and the new data obtained from professionals, a detailed life-cycle cost study is conducted. In this life-cycle cost study, several variables, such as initial costs, electricity costs and maintenance costs are considered and a sensitivity analysis has been performed. The effect of variation in electricity prices and tax credits and rebates are studies. Also, data gathering procedures are presented along with the new data.

\section{2 - Research Objectives}

The goal of the study is to present the methodology to follow for a life-cycle cost analysis of GSHP system and study the effect of the cost items on the feasibility of GSHP 
systems. The effect of fluctuations in electricity prices and federal and local incentives can make a significant impact on the cost-effectiveness of the GSHP system. The study is focused on finding the outcome of these possible variations and how it can affect the usage of GSHP systems for a simulated typical building and actual projects visited. Parallel to this goal, the research aims to identify these cost items in a practical and accurate fashion.

The second aim of this study was to collect cost and design data for different GSHP systems for evaluation of the life-cycle cost model developed. The applicability of the developed model is assessed. Furthermore, the opinions of professionals met during the visits will be conveyed and possible ways of reducing costs and expanding the usage of GSHP systems will be discussed.

In a broader sense, the general objective of the study is to study the cost effectiveness of GSHP systems and exhibiting the effect of uncertainties in certain parameters. As green buildings gain more recognition and incentives and tax rebates promote these alternatives, GSHP systems will be considered more seriously in HVAC domain and this study aims to present a feasibility study.

\section{3 - Research Methodology}

For the purpose of advancing the knowledge in cost aspects of GSHP systems, initially literature have been searched and studies in this subject are presented. 
Information regarding initial costs, maintenance costs, and energy costs has been reviewed. Later on, this data have been used in certain locations along with the data obtained from R.S. Means (2010) to build up the life-cycle cost items used in the study.

While performing these, a single-family residential unit is used as a basis. The capacity and electricity consumption of the unit has been calculated for the GSHP systems using the eQUEST energy simulation software. For demonstrating a comparison example, a conventional HVAC system is used and the same life-cycle costs are calculated for that system as well.

After definition and assessment of all cost items, net present value for both systems is calculated using a determined inflation rate. The life-cycle cost analysis option of eQUEST has been used while conducting this calculation. Then, possible variations that can be observed during the life time of the GSHP alternative have been assessed and the results of these changes are calculated. Using the actual data gathered during trips made, this process is repeated for several projects. The sensitivity of cost items and the total life-cycle cost is assessed and the variation of cost effectiveness of GSHP system has been presented in comparison to the conventional system.

\section{4 - Thesis Organization}

This thesis consists of five chapters, including this introductory chapter. Chapter 2 presents a review of literature on studies conducted about the cost aspects of GSHP 
systems as well as studies regarding life-cycle cost estimating methodologies. In this chapter, the available data regarding the energy consumption, initial costs, maintenance costs and periodic costs of GSHP systems will be presented.

Chapter 3 describes the data gathering efforts, surveys prepared for this purpose, methods of contacting individuals in the industry and responses received. The cost and system information obtained for several GSHP projects are presented in detail. Moreover, the opinions of professionals on development of GSHP industry and possible ways to expand this technology are explained

Chapter 4 is devoted to detailed comparative life-cycle cost analysis of the GSHP systems. The details regarding the simulation and methodology followed are presented. The information regarding the GSHP system and conventional HVAC system is given. The life cycle cost calculations and sensitivity analysis, done for GSHP systems and a conventional system is also explained in this chapter. Then, general conclusions drawn from sensitivity analysis have been presented.

Chapter 5 summarizes the research, and underlines the outcomes. The conclusions obtained from life-cycle costs analysis of GSHP systems are presented along with observations made during data gathering process. Finally, recommendations for future work are presented. 


\section{2 - Literature Review}

\section{1 - Cost Aspects of Ground Source Heat Pump Systems}

Stating the need for a better established cost data about GHSP systems, many studies aimed to expand the knowledge on this area. Several studies focused on GSHP system cost data alone, while many did a comparison with conventional systems on case basis.

Lienau (1997) studied the performance of GSHP systems from an energy perspective. He collected performance data for 217 systems installed in schools, residential and commercial buildings and used 65 of these to compare them with other HVAC alternatives. He focused on parameters such as heat pump demand and energy, supply and returns ground-loop temperatures, flow in the ground loop, air flow, air supply and return temperatures, space and outside temperatures. For residential units, GSHP systems are reported to use 33\% less energy than air-source heat pumps, and 52\% less energy than electrical resistance systems. Also, it was stated that the payback period of GSHP systems was 4.3 years in average for residential units. For commercial buildings, the energy savings were reported to be in the same range.

Martin et al. (1999) investigated the maintenance costs of GSHP systems and compared them with other HVAC systems in Lincoln School District, Nebraska. In their study, they focused on repair, service and corrective maintenance of the systems in 20 schools in the region. Based on the regular records of the district, they compared schools 
with vertical closed loop GSHP, air-cooled chiller with gas-fired hot water boiler (ACC/GHWB), water-cooled chiller with gas-fired hot water boiler (WCC/GSB) and water-cooled chiller with gas fired steam boiler (WCC/GSB). They analyzed these costs per $\mathrm{ft}^{2}$ of the schools for a period of two to three years. It was found out that schools with GSHP systems have the lowest annual repair, service and corrective maintenance costs with $0.0213 \$ / \mathrm{ft}^{2}$ per year. GSHP systems were followed by ACC/GHWB systems with $0.0288 \$ / \mathrm{ft}^{2}$ per year, WCC/GSB systems with $0.0373 \$ / \mathrm{ft}^{2}$ per year and, WCC/GHWB systems with $0.0607 \$ / \mathrm{ft}^{2}$ per year. They also noted that there is a direct relation between the age of system and costs analyzed.

Bloomquist (2001) performed a study about the economics of GSHP systems for commercial and institutional buildings. Studying the data available in literature, he stated that GSHP systems can offer considerable savings and maintenance costs compared to other HVAC systems. He also underlined the lack of data and necessity of further research in the area.

Chiasson et al. (2004) analyzed a hybrid GSHP system proposed for an existing school building in Wyoming. Using a whole system approach in design and simulation they compared the new hybrid GSHP system with existing gas-fired hot water boiler system. Authors concluded that GSHP systems can be installed cost effectively to existing structures and pay back the initial costs in less than 10 years. 
Chiasson (2006) prepared a report on life cycle cost analysis of three different HVAC alternatives for an office building in Nebraska. The systems considered for the study were rooftop units with gas heat and direct expansion (DX) cooling, air-source heat pumps, and GSHP. For the purpose of comparison, net present values of 30 year lifecycle costs of these systems were calculated. The capital cost of GSHP systems were higher compared to other two options. But because of low energy consumption and maintenance costs of the GSHP alternative was found out to be more favorable than the others. It was calculated that proposed GSHP system has a simple payback period of 6.6 years with respect to second best alternative. It was estimated that the building will have a peak cooling load of $264,000 \mathrm{Btu} / \mathrm{hr}$ and a peak heating load of $178,000 \mathrm{Btu} / \mathrm{hr}$. Also annual energy consumptions were calculated to be $246 \mathrm{kBtu}$ for heating and $479 \mathrm{kBtu}$ for cooling. A summary of life-cycle cost of the three evaluated alternatives is presented in Table 1.

Table 1 - Life Cycle Cost Estimates of the Three Systems Considered (Chiasson, 2006)

\begin{tabular}{|c|c|c|c|c|c|}
\hline \multirow{2}{*}{ HVAC System } & \multirow{2}{*}{$\begin{array}{l}\text { Capital } \\
\text { Cost, } \\
(\$)\end{array}$} & \multicolumn{2}{|c|}{ Annual Costs, (\$) } & \multirow{2}{*}{$\begin{array}{l}\text { Periodic } \\
\text { Costs, }(\$)\end{array}$} & \multirow{2}{*}{$\begin{array}{c}\text { Net Present Value } \\
\text { of } 30 \text {-year Life- } \\
\text { Cycle Cost, }(\$)\end{array}$} \\
\hline & & Energy & Maintenance & & \\
\hline $\begin{array}{l}\text { Rooftop units } \\
\text { with gas heat and } \\
\text { DX cooling }\end{array}$ & 114,610 & 8,226 & 4,476 & $\begin{array}{c}40,000 \text { at } \\
\text { year } 17\end{array}$ & 299,020 \\
\hline $\begin{array}{l}\text { Air-source heat } \\
\text { pumps }\end{array}$ & 139,824 & 6,803 & 4,069 & $\begin{array}{c}50,000 \text { at } \\
\text { year } 17\end{array}$ & 301,922 \\
\hline GSHP & 160.600 & 3,852 & 1,889 & $\begin{array}{c}30,000 \text { at } \\
\text { year } 20\end{array}$ & 245,634 \\
\hline
\end{tabular}


Chiasson (2006) conducted another study on feasibility of a GSHP system planned to be installed in a new school building at Idaho. For the building, the design of a propane heating, direct expansion HVAC system was already installed. The peak heating and cooling loads of the building were estimated to be 2.9 million Btu/hr and 1.375 million Btu/hr, respectively. The annual heating and cooling loads were calculated as 1.04 billion Btu and 483 million Btu. Keeping the main design same, author converted to this an open loop GSHP systems and conducted a life-cycle costing study to assess its feasibility. The life-cycle cost estimates of the two alternatives are presented in Table 2. The analysis showed that GSHP system considered had a payback period of 6.5 years.

Table 2 - Life-Cycle Cost Estimates of the Two Systems Considered (Chiasson, 2006)

\begin{tabular}{|c|c|c|c|c|c|}
\hline \multirow{2}{*}{ HVAC System } & \multirow{2}{*}{$\begin{array}{c}\text { Capital } \\
\text { Cost, } \\
(\$)\end{array}$} & \multicolumn{2}{|c|}{ Annual Costs, (\$) } & Periodic & $\begin{array}{c}\text { Net Present Value } \\
\text { of 30-year Life- } \\
\text { Cycle Cost, (\$) }\end{array}$ \\
\cline { 3 - 5 } & & Energy & Maintenance & Costs, (\$) & \\
\hline $\begin{array}{c}\text { Rooftop units } \\
\text { with propane } \\
\text { heating and DX } \\
\text { cooling }\end{array}$ & 519,332 & 25,966 & 3,541 & $\begin{array}{c}55,000 \text { at } \\
\text { year } 17\end{array}$ & $1,001,776$ \\
\hline $\begin{array}{c}\text { GSHP } \\
\text { (open loop wells) }\end{array}$ & 633,992 & 8,086 & 4,721 & $\begin{array}{c}25,000 \text { at } \\
\text { year 20 }\end{array}$ & 750,659 \\
\hline
\end{tabular}

The cost breakdown for the open-loop GSHP system considered is as shown in Table 3. For the conventional system, the costs were calculated using R.S. Means and deducted from the cost of GSHP system to reach the incremental cost. For the capital costs of GSHP system, cost data from two similar projects were used. 
Table 3 - Life-Cycle Cost Breakdown for the GSHP system considered (Chiasson, 2006)

\begin{tabular}{|c|c|c|c|c|c|}
\hline & Unit & Quantity & $\begin{array}{l}\text { Unit Cost, } \\
(\$)\end{array}$ & $\begin{array}{l}\text { Amount, } \\
(\$)\end{array}$ & $\begin{array}{c}\text { Totals, } \\
(\$)\end{array}$ \\
\hline \multicolumn{6}{|l|}{ Initial Costs } \\
\hline \multicolumn{6}{|l|}{ Design and Engineering } \\
\hline Pre-design meetings, etc & $\mathrm{hr}$ & 24 & 100 & 2400 & \\
\hline Engineering re-design & $\%$ & $5 \%$ & 600,326 & 30016 & \\
\hline \multirow[t]{2}{*}{ Construction oversight } & $\mathrm{hr}$ & 25 & 50 & 1250 & \\
\hline & & & & 33,666 & \\
\hline \multicolumn{6}{|l|}{ Equipment and Installation } \\
\hline GSHP installation Cost ${ }^{1}$ & $\mathrm{ft}^{2}$ & 47212 & 11.50 & 542,938 & \\
\hline Drilling, well completion $^{2}$ & $\mathrm{~m}$ & 152 & 246.06 & 37,500 & \\
\hline Well flow testing & lump & 1 & 1,500 & 1,500 & \\
\hline Trenching and backfilling & $\mathrm{m}$ & 100 & 25 & 2,500 & \\
\hline Well pumps and controls ${ }^{3}$ & $\mathrm{~kW}$ & 7.2 & 750 & 10,851 & \\
\hline Plate heat exchangers & $\mathrm{kW}$ & 403 & 12.50 & 5,037 & \\
\hline \multirow[t]{2}{*}{ Conventional system credit } & $\mathrm{ft}^{2}$ & 47212 & -11 & $-519,332$ & \\
\hline & & & & 80.994 & \\
\hline Annual Costs & & & & & 114,660 \\
\hline \multicolumn{6}{|l|}{ Energy use savings } \\
\hline \multirow[t]{2}{*}{$\begin{array}{c}\text { Incremental maintenance } \\
\text { savings }\end{array}$} & $\mathrm{ft}^{2}$ & 47212 & -0.025 & -1.180 & \\
\hline & & & & & 16,700 \\
\hline Periodic Costs & Years & & & & \\
\hline Outdoor replacement & 17 & & & 55000 & \\
\hline Pumps, heat exchanger & 20 & & & 25,000 & \\
\hline
\end{tabular}

'Includes all "inside the building" materials and labor

${ }^{2}$ Two wells, 250 feet deep each

${ }^{3}$ One primary and one back up

${ }^{4}-\$ 0.075 / \mathrm{ft}^{2}$ for conventional system, $\$ 0.10$ for GSHP system

Moore (1999) compared the economics of GSHP systems and several other GSHP alternatives. The cost data gathered was sorted according to building types and types of 
earth connections systems utilize. As seen in Table 4, the compiled data was presented as cost per square foot and cost for ton of cooling capacity.

Table 4 - GSHP System Capital Costs by Building and Earth Connection Types (Moore, 1999)

\begin{tabular}{|c|c|c|c|c|}
\hline Average of: & $\begin{array}{c}\text { GSHP System } \\
\text { Capital Cost per } \\
\mathrm{ft}^{2},(\$)\end{array}$ & $\begin{array}{l}\text { Number } \\
\text { of Data } \\
\text { Points }\end{array}$ & $\begin{array}{l}\text { GSHP System } \\
\text { Capital Cost per } \\
\text { ton of cooling } \\
\text { capacity, }(\$)\end{array}$ & $\begin{array}{l}\text { Number } \\
\text { of Data } \\
\text { Points }\end{array}$ \\
\hline $\begin{array}{c}\text { All case studies and } \\
\text { references }\end{array}$ & 100.10 & 72 & 3,593 & 55 \\
\hline \multicolumn{5}{|l|}{ Building Type } \\
\hline Schools & 115.40 & 32 & 3,572 & 24 \\
\hline Office Buildings & 85.00 & 13 & 3,518 & 11 \\
\hline Retail & 35.90 & 5 & 3,841 & 3 \\
\hline Medical Centers & 84.10 & 2 & 2,839 & 2 \\
\hline Retirement & 126.20 & 3 & 3,917 & 2 \\
\hline $\begin{array}{l}\text { Apartment / Multi- } \\
\text { residential }\end{array}$ & 100.00 & 2 & 3,707 & 2 \\
\hline Prisons & 134.90 & 3 & 4,622 & 2 \\
\hline $\begin{array}{c}\text { Gas Station / Convenience } \\
\text { Store } \\
\end{array}$ & 232.40 & 1 & 6,833 & 1 \\
\hline \multicolumn{5}{|l|}{ Earth Connection Type } \\
\hline Vertical Closed Loop & 117.90 & 50 & 3,874 & 39 \\
\hline Horizontal Closed Loop & 55.10 & 8 & 2,512 & 6 \\
\hline Open Loop & 55.00 & 7 & 2,987 & 5 \\
\hline Hybrid & 112.70 & 1 & 5,125 & 1 \\
\hline
\end{tabular}

For comparison purposes capital costs of other main HVAC systems were presented as in Table 5. It was noted that the collected data for conventional systems were in good agreement with R.S. Means standards for large facilities. Furthermore, 
utility costs of GSHP systems were collected from case studies and they were compared with estimated energy consumption of other HVAC systems. These data along with savings in percentage is shown in Table 6. In addition to these factors, Moore used an annual maintenance cost of $\$ 1.40 / \mathrm{ft}^{2}$ for life-cycle cost estimating in his study.

Table 5 - Capital Costs of Conventional HVAC Systems

\begin{tabular}{|c|cc|}
\hline HVAC System Type & $\begin{array}{c}\text { Capital Cost per } \\
\mathrm{ft}^{2},(\$)\end{array}$ & $\begin{array}{c}\text { Number } \\
\text { of Data } \\
\text { Points }\end{array}$ \\
\hline $\begin{array}{c}\text { Rooftop direct expansion (DX) with electric } \\
\text { heating }\end{array}$ & 52.00 & 2 \\
\hline Rooftop DX with gas heating & 61.00 & 5 \\
\hline Air-source heat pump & 74.70 & 3 \\
\hline Rooftop variable air volume (VAV) & 86.10 & 4 \\
\hline $\begin{array}{c}\text { Water-source heat pump with gas boiler \& } \\
\text { cooling tower }\end{array}$ & 133.40 & 8 \\
\hline $\begin{array}{c}\text { Central VAV with chiller, cooling tower \& gas } \\
\text { perimeter heat }\end{array}$ & 161.60 & 8 \\
\hline $\begin{array}{c}\text { Four-pipe fan coil unit with electric chiller\& gas } \\
\text { boiler }\end{array}$ & 170.70 & \\
\hline
\end{tabular}


Table 6 - Energy Consumption data of GSHP and conventional GSHP systems (Moore, 1999)

\begin{tabular}{|c|c|c|c|c|c|}
\hline \multirow{2}{*}{$\begin{array}{l}\text { Weighted Average } \\
\text { of: }\end{array}$} & \multicolumn{4}{|c|}{$\begin{array}{l}\text { Annual Building Energy Costs }\left(\$ / \mathrm{ft}^{2}\right) \& \\
\text { Number of Data Points }\end{array}$} & \multirow{2}{*}{$\begin{array}{l}\text { Savings } \\
(\%)\end{array}$} \\
\hline & $\begin{array}{l}\text { GSHP } \\
\text { System }\end{array}$ & $\begin{array}{c}\text { Number } \\
\text { of Data } \\
\text { Points }\end{array}$ & $\begin{array}{l}\text { Conventiona } \\
1 \text { System }\end{array}$ & $\begin{array}{c}\text { Number } \\
\text { of Data } \\
\text { Points }\end{array}$ & \\
\hline \multicolumn{6}{|l|}{ Building Type } \\
\hline $\begin{array}{l}\text { All case studies } \\
\text { and references }\end{array}$ & 8.00 & 52 & 11.20 & 42 & 29 \\
\hline Schools & 5.90 & 22 & 9.20 & 19 & 36 \\
\hline Office Buildings & 9.90 & 10 & 13.90 & 8 & 29 \\
\hline Retail & 5.80 & 4 & 9.50 & 3 & 39 \\
\hline Retirement & 9.50 & 2 & 13.30 & 3 & 26 \\
\hline Prisons & 11.90 & 3 & 12.20 & 1 & 2 \\
\hline $\begin{array}{c}\text { Gas Station / } \\
\text { Convenience Store }\end{array}$ & 89.90 & 1 & 122.30 & 1 & 26 \\
\hline \multicolumn{6}{|l|}{$\begin{array}{l}\text { Earth Connection } \\
\text { Type (Location) }\end{array}$} \\
\hline $\begin{array}{l}\text { Vertical Closed } \\
\text { Loop Locations }\end{array}$ & 4.70 & 6 & 8.90 & 3 & 47 \\
\hline $\begin{array}{l}\text { Horizontal Closed } \\
\text { Loop Locations }\end{array}$ & 8.20 & 34 & 11.30 & 33 & 27 \\
\hline $\begin{array}{c}\text { Open Loop } \\
\text { (Groundwater) } \\
\text { Locations }\end{array}$ & 8.10 & 6 & 1050 & 3 & 23 \\
\hline
\end{tabular}


Kavanaugh et al. (1995) conducted a comprehensive study about initial costs of GSHP systems. Based on the data they gathered from people in GSHP industry, they broke up the cost components and classified them according to types of systems. They stated that the cost of A GSHP system is in the range of $\$ 2,360$ to $\$ 3,000$ per ton of capacity. The breakdown of cost components are shown in Figure 1 for 3 ton GSHP systems. In the study, it was stressed that there's a big potential in reducing the capital costs of these systems, which will be realized as industry develops.

Holihan (1998) prepared a report focused on the manufacturing number of heat pumps. He also studied the advantages of disadvantages of GSHP systems and provided opinions about the obstacles to wider utilization of these systems. The information he gathered is presented in Table 7. This information was collected to find out the penetration of GSHPs to the heat pump market. The author noted that the numbers are for the pumps manufactured in the United States. The ARI-302 refers to water source heat pumps which are manufactured for use in commercial buildings and they are not classified as a GSHP. ARI-325 means heat pumps which are designed for use in openloop systems and ARI-330 defines the pumps which are used in closed-loop systems. The author underlined that the increase in 1997 was mostly due to educational activities, promotions and rebates offered. It was also stated that the average capacity of the heat pumps shipped in 1997 was 3.8 tons. 


\section{GSHPSystem with Horizontal Loop}

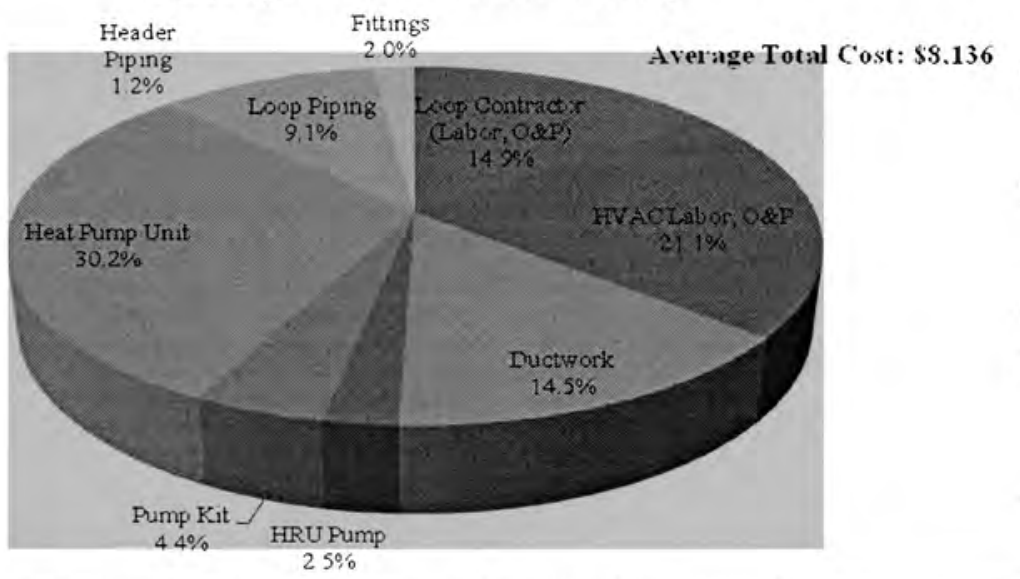

GSHPSystem with Slinky Loop

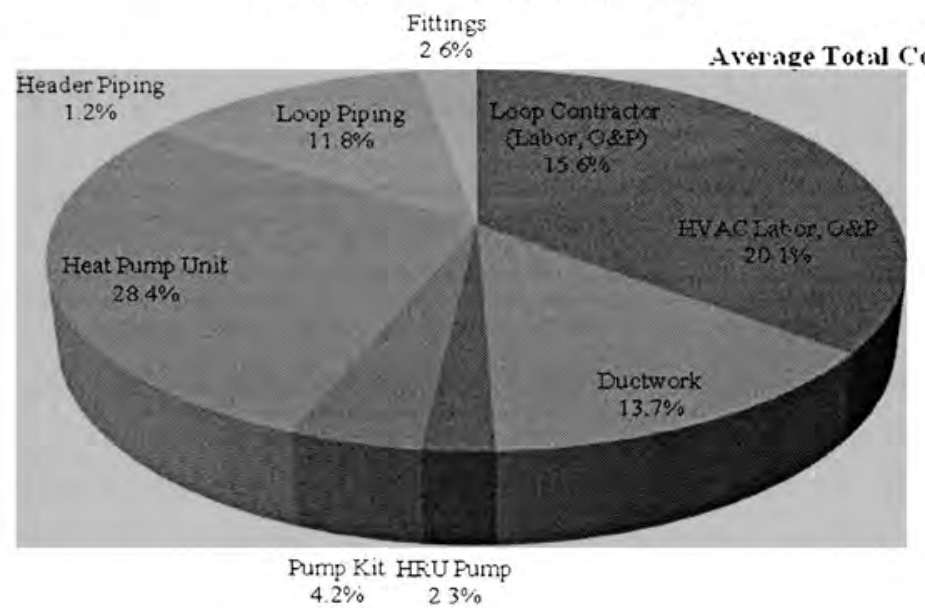

GSHPSystem with Vertical Loop

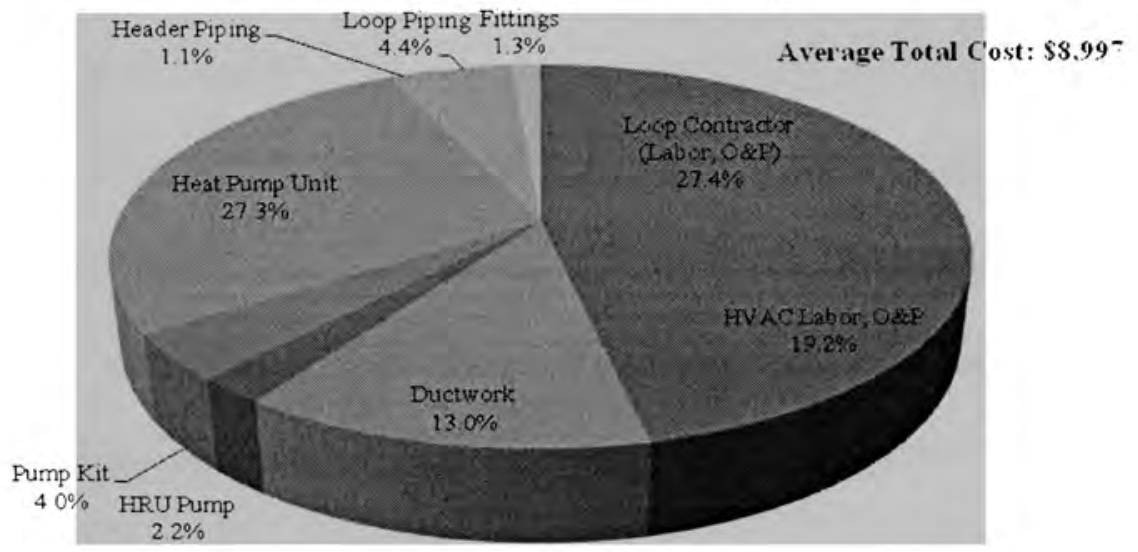

Figure 1- Cost Breakdown of 3 ton GSHP systems (Kavanaugh et al., 1995) 
Table 7 - Heat Pump Shipments between 1994 and 1997 (Holihan, 1998)

\begin{tabular}{|c|c|c|c|c|}
\hline Model Type & 1994 & 1995 & 1996 & 1997 \\
\hline ARI-320 & 539 & 4851 & 4318 & 7494 \\
\hline ARI-325 & 8924 & 8615 & 7603 & 9724 \\
\hline ARI-330 & 16023 & 18185 & 18094 & 18611 \\
\hline Non-ARI Rated & 757 & 838 & 991 & 1327 \\
\hline Total & 28094 & 32486 & 31006 & 37156 \\
\hline
\end{tabular}

Hollihan (1998) also underlined that the potential of energy savings that the GSHP systems offer and discussed the common barriers to wider usage. He stated that initial costs in GSHP systems are higher than that of conventional HVAC alternatives. Noting that the payback period for GSHP systems can be in the range of 2 to 10 years but still, the loop or well drilling costs usually defer user from choosing this alternative. Also lack of information, advertisement and user's concerns for this technology were listed among these barriers. Whereas, the rebates and low interest loans offered were considered as primary factors facilitating the growth in this relatively new technology.

Department of Defense (DoD) (2007) submitted a report to congress about GSHP systems used and planned in DoD facilities. In this report, description and system specifics about all GSHP systems present in DoD facilities were explained in detail. In addition to that, cost-effectiveness of these systems and their suitability has been evaluated for different geographic locations within continental USA. Barriers to GSHP systems and recommendations that can magnitude the usage of these systems are also explained in this report. It was noted down that the total capacity of GSHP systems used in DoD facilities are more than 52,000 tons and it was pointed that they were mostly on 
the eastern half of USA. Also, hybridized system were considered to be the cost effective in the Northeast, Southwest, Western Mountain, Northwest and West Coast regions of the United States.

In this report, certain factors that impact the efficiency and cost effectiveness of the GSHP systems were pointed. They were noted as: geotechnical and climatic conditions, type of GSHP system utilized, system's size, and characteristics of the building, availability of local professionals and infrastructure, capability of using a hybrid system, efficiency and cost of the other alternatives or existing HVAC system.

DoD recommended several implementations in order to facilitate the usage of GSHP systems. These can be listed as:

- Further education of professionals in the industry, who took role in design and managing are necessary.

- Government should establish an institution that will help designers and provide a medium for discussion of problems.

- A specification including consistency, applicability and evaluation of new technologies should be established and reviewed with regular time intervals.

- The HVAC design manual was published by American Society of Heating Refrigeration and Air-conditioning Engineers (ASHRAE) in 1997. As the technology advances, an update becomes a necessity. 
- Soil properties, which are among the most critical site parameters, are usually unavailable. A database should be created and this information should be collected there.

- In order to find out the potential areas where GSHP systems can be life-cycle cost effective, screening efforts should be continued.

DoD made an analysis based on the cost data gathered and calculated the payback periods sorted according to the locations of projects. It was found out that the projects in the eastern states had the lowest payback periods, lowest being the northeast region. Simulations which took into account 3 different soil types and several possible locations for same type of building, yielded similar results, indicating that GSHP systems may not be feasible at western coast due to small loads and shorter runtimes. Furthermore, it was stated the initial cost of the GSHP systems show a linear trend with the capacity (tons). The average cost of a residential system was $\$ 4600 /$ ton for residential units and $\$ 7000 /$ ton for commercial buildings.

Fredin (2009) compared the life-cycle costs of GSHP systems and a conventional HVAC system. For this study, a GSHP system having a vertical closed loop was chosen as it is one of the most common types and as it can be built almost anywhere, being less sensitive to geographical variations. For the baseline system with a natural gas furnace and a conventional air-conditioning (NGAC) was selected. The life-cycle costs were calculated for 51 different locations throughout the United States. This took account into 
climatic changes but the soil was assumed to be the same for all locations with no rock layer formation.

In this study, initial cost calculations and maintenance costs were mostly dependent on RS Means data. The annual energy costs were estimated using the values obtained from system manufacturers specification. The initial costs calculated for GSHP and NGAC systems are presented in Figure 2. The annual operating costs that have been calculated for these two different systems are given in Figure 3 for different locations. After conducting the life-cycle cost calculations, the initial payback periods for different projects in different states are shown in Figure 4. It was noted down that GSHP systems perform poorly in Alaska, not having a payback period over NGAC systems. Also, the locations where high cooling loads and relatively high ground temperatures exist had high payback periods. It was found out that GSHP systems are $257 \%$ higher than in initial cost and 33\% lower in operational costs compared to NGAC systems. 


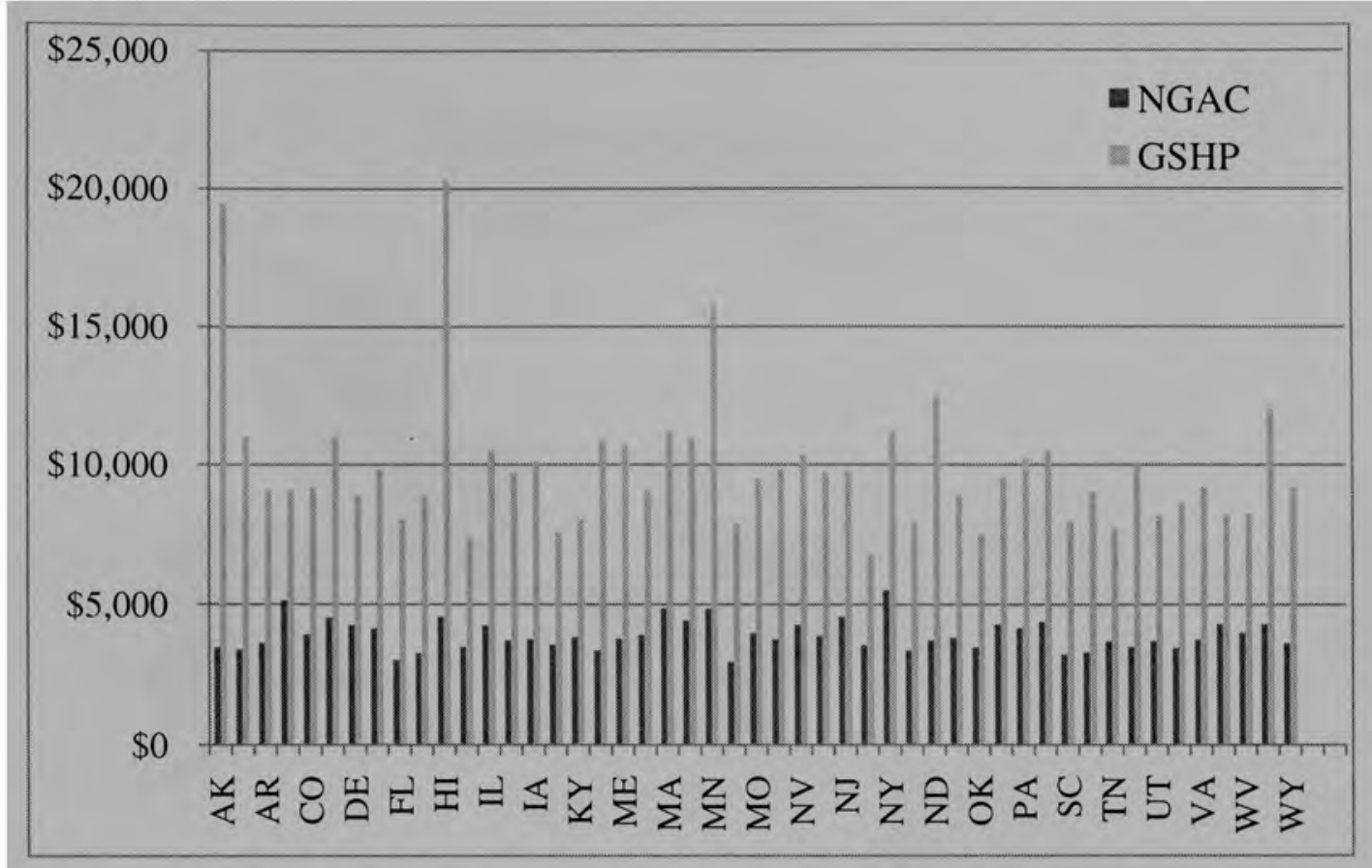

Figure 2 - Costs for two different systems in different locations (Fredin, 2009)

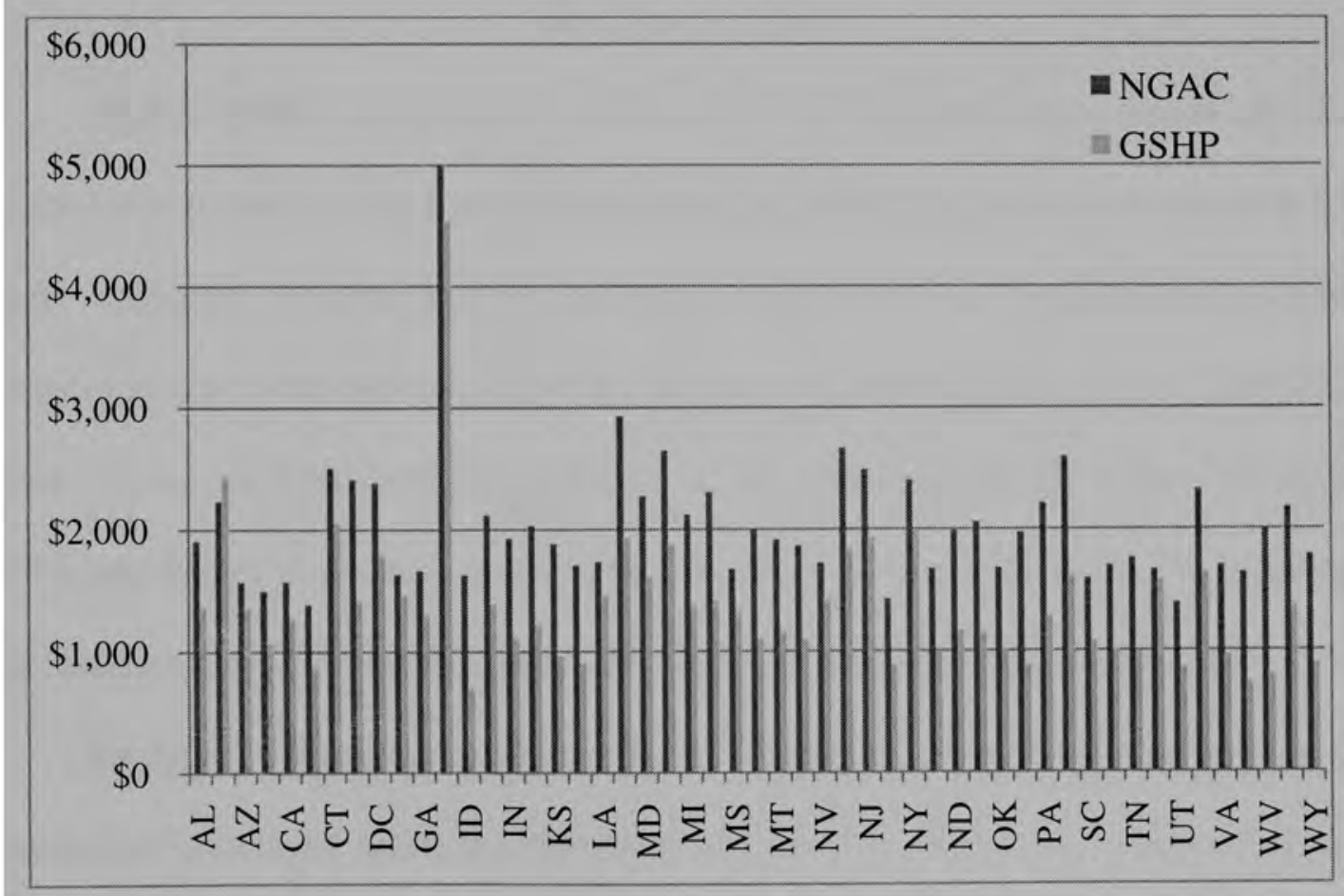

Figure 3 - Annual operating costs for two different systems in different locations (Fredin, 2009) 


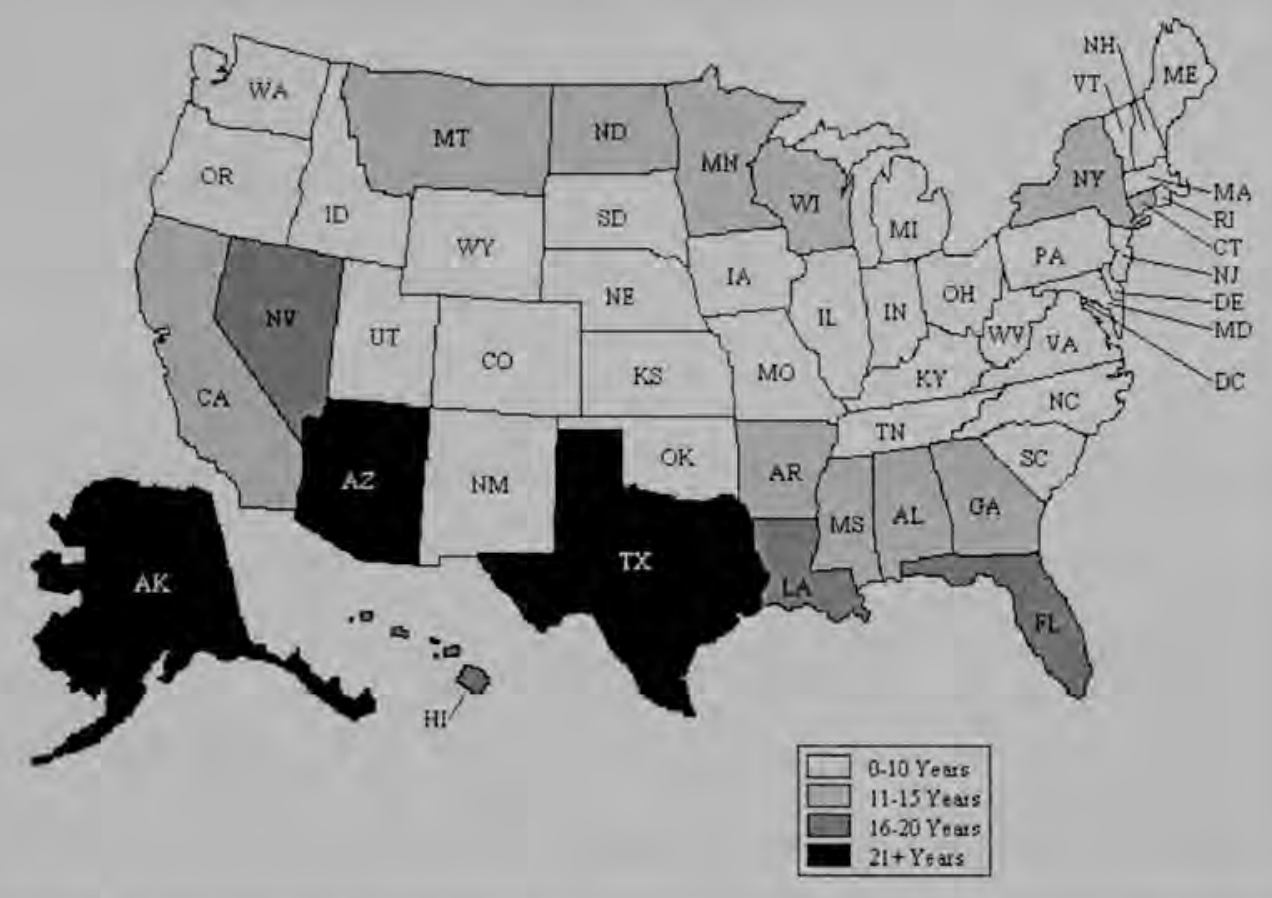

Figure 4 - Payback periods of GSHP systems compared to NGAC systems in different states (Fredin, 2009)

Trahan (2009) performed a study in order to find the energy usage of GSHP system to be financially attractive for a specific building. The case study was done for a highly insinuated monolithic dome building in Fort Irwin, CA which creates its own electrical energy. A conventional HVAC system was compared to a closed loop GSHP system. It was concluded that in order to be cost effective, GSHP system should use $37.9 \%$ less energy than conventional system for a life cycle of 30 years. The same ratio was calculated as $41.3 \%$ for a 20 years life cycle and $54.9 \%$ for 10 years life cycle.

Hughes (2008) prepared a report about the barriers among GSHP technology and potential actions to be taken to overcome them. In this report, this was written upon Department of Energy's request, the author suggested that ground heat exchanger may be considered as a permanent infrastructure investment by government and several other 
financial incentives can be evaluated. In this study, barriers found were listed as below in the order of importance:

1. High initial costs from consumer's point of view

2. Inadequate user knowledge and insufficient level of confidence about GSHP system's advantages

3. Insufficient information background of policymakers and regulators and low level of trust to GSHP system advantages

4. Limits and restrictions in designing of GSHP systems and planning of infrastructure for business

5. Limits and restrictions in infrastructure for installation of GSHP systems

6. Absence of new improvements and techniques that could potentially increase the cost effectiveness and performance of GSHP systems

In order to overcome these barriers and increase the usage of GSHP systems, certain points were made. For overall national economic progress and decrease the energy usage, following guidelines were recommended:

1. Gather and organize consistent data regarding GSHP system costs and benefits

2. Evaluate the benefits of rapid implementation of GSHP systems to the nation

3. Increase the efficiency of and implement programs that will supply GSHP system infrastructure to the nation

4. Build up and implement programs that will enable users to access GSHP infrastructure universally 
5. Implement a program, a database to find means that will provide the lowest life-cycle cost for a GSHP system infrastructure

6. Increase the locations where superior GSHP infrastructure is developed

7. Increase the locations where superior GSHP installation infrastructure is developed

Hughes and Shonder (1998) performed a study about a massive GSHP installation project that has been.completed in army base in Fort Polk, LA. The project consisted of implementation of GSHP systems to 4003 residential units which were previously using air source heat pumps or central air conditioners, natural gas forced air furnaces and natural gas fired water heaters. This retrofit was undertaken with an energy savings performance contract (ESPC) which requires the contractor to purchase, install the GSHP systems as well as do the maintenance of the systems during the 20 years period. In return, the contractor will receive payments calculated through the savings made as a result of retrofitting. With baseline energy consumption adjustments done for every year, the contract was agreed on terms with an amount of $77 \%$ of savings paid to the contractor.

As a part of this program, insulation on some of the buildings was improved, lowflow shower heads were installed and fluorescent lightning was implemented at units. GSHP systems installed had a total capacity of 6593 tons and a mean capacity of 1.65 tons. The domestic water heating of the houses were also achieved through these GSHP systems. 
The study revealed that this retrofit will save 25.8 million $\mathrm{kWh}$ under typical weather conditions. This savings means a reduction of $32.5 \%$ in electricity consumption and $100 \%$ reduction in natural gas use compared to older system. Also, this project led to a significant decline in $\mathrm{CO}_{2}$ emissions. It was calculated that emissions were decreased by 22,400 tons annually. Furthermore, it was estimated that there was a reduction of 7.55 MW in summer peak electrical demand, which can be translated into a $43.5 \%$ decrease with respect to pre-retrofit situation.

Another major amount of saving resulted from maintenance savings for this project. The average maintenance cost of pre-retrofit stage was $\$ 396.05$ per house, or 26 cents/ft ${ }^{2}$, annually. In the contract, the two parties agreed upon a baseline maintenance cost of 24.1 cents $/ \mathrm{ft}^{2}$ per annum. The army pays $77 \%$ of this baseline amount to the contractor, the contractor being responsible for the maintenance of the whole system. Overall, from the army's perspective, the project will begin saving money instantly. Also, energy consumption and carbon emission will decline. This shows that the GSHP systems offer a win-win opportunity for the both parties involved in such a contract. 


\section{3 - Data Collection and Observations}

\section{1 - Data Collection Efforts}

In order to collect data and interact with professionals who have been working in GSHP industry, several efforts were made. Initially, contact information of several GSHP contractors and other professionals in this industry has been acquired through internet. Then, individuals were contacted in order to see their interest in sharing any information they have regarding GSHP system design or installation. About $10 \%$ of all individuals have replied. Out of these, some of them sent information via telephone and email. Surveys prepared for gathering information regarding GSHP system specific can be found in the Appendix.

Two locations were visited with a research group to see the projects in place and collect information. The first trip was made to Tampa area and the second trip was to Pensacola area. The information gathered for 5 different projects are presented below. Opinions of professionals about the obstacles to GSHP system usage are also presented in this section.

\subsection{1 - Trip to Tampa and Information Gathered}

On the trip to Tampa, two residential houses were visited and information regarding four residential units was gathered through surveys after the trip. The information regarding these residential applications is presented below. 
The first house was built on 1986. The house used the conventional air cooled air conditioning system till April 2010 that changed to GSHP. Table 8 shows the general information about the building and GSHP system. The cost summary of the system is presented in Figure 5.

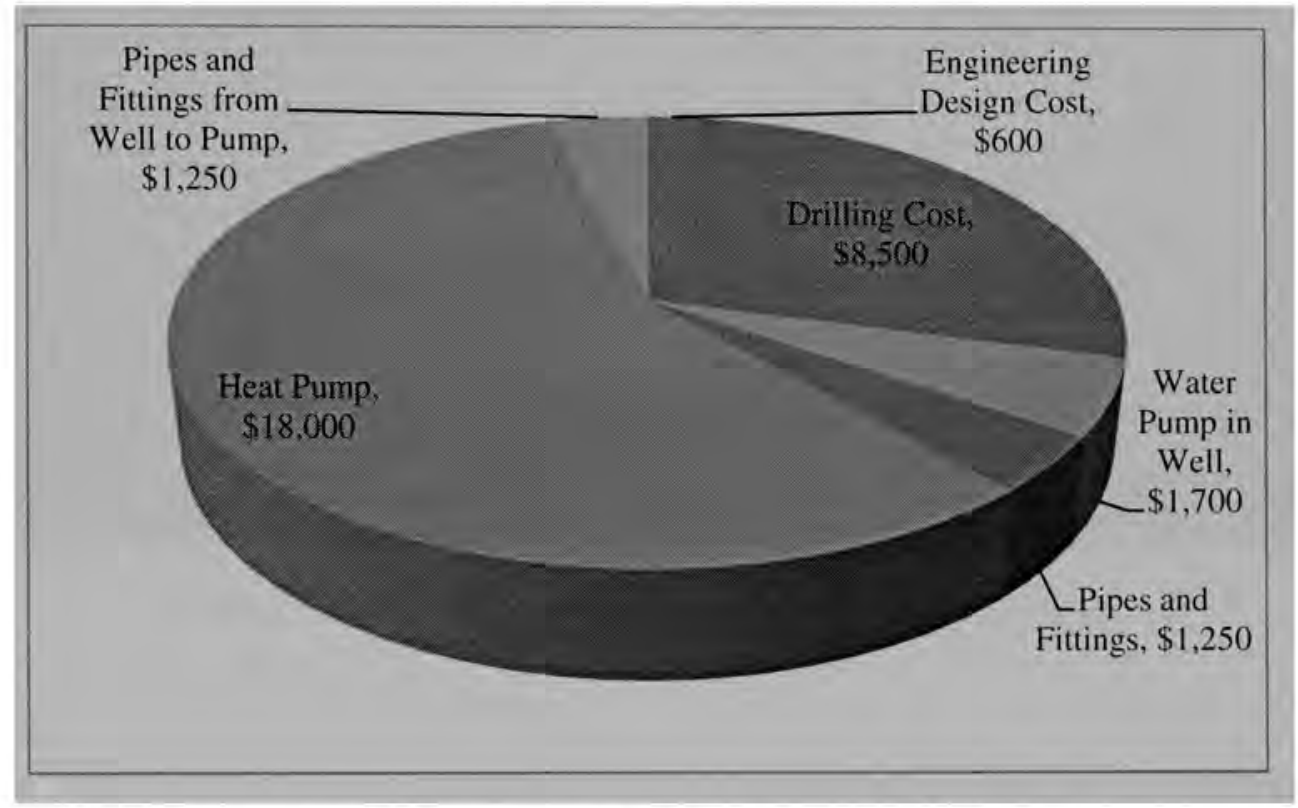

Figure 5- Cost Breakdown of First Residential Building

The system uses a two well open loop system with $80 \mathrm{ft}$ depth and $60 \mathrm{ft}$ well spacing. The pump characteristics are: $1 \mathrm{HP}, 8 \mathrm{~A}$, and $220 \mathrm{~V}$. The heat pump is single phase that uses a 2 speed compressor and the refrigerant is R410a. Two PT ports are available for temperature and pressure measurements. The building's wall is traditional Florida block wall and its roof type is R33 that 1 inch foam has been blown on it. Some components of this system are given in Figures 6, 7 and 8. 


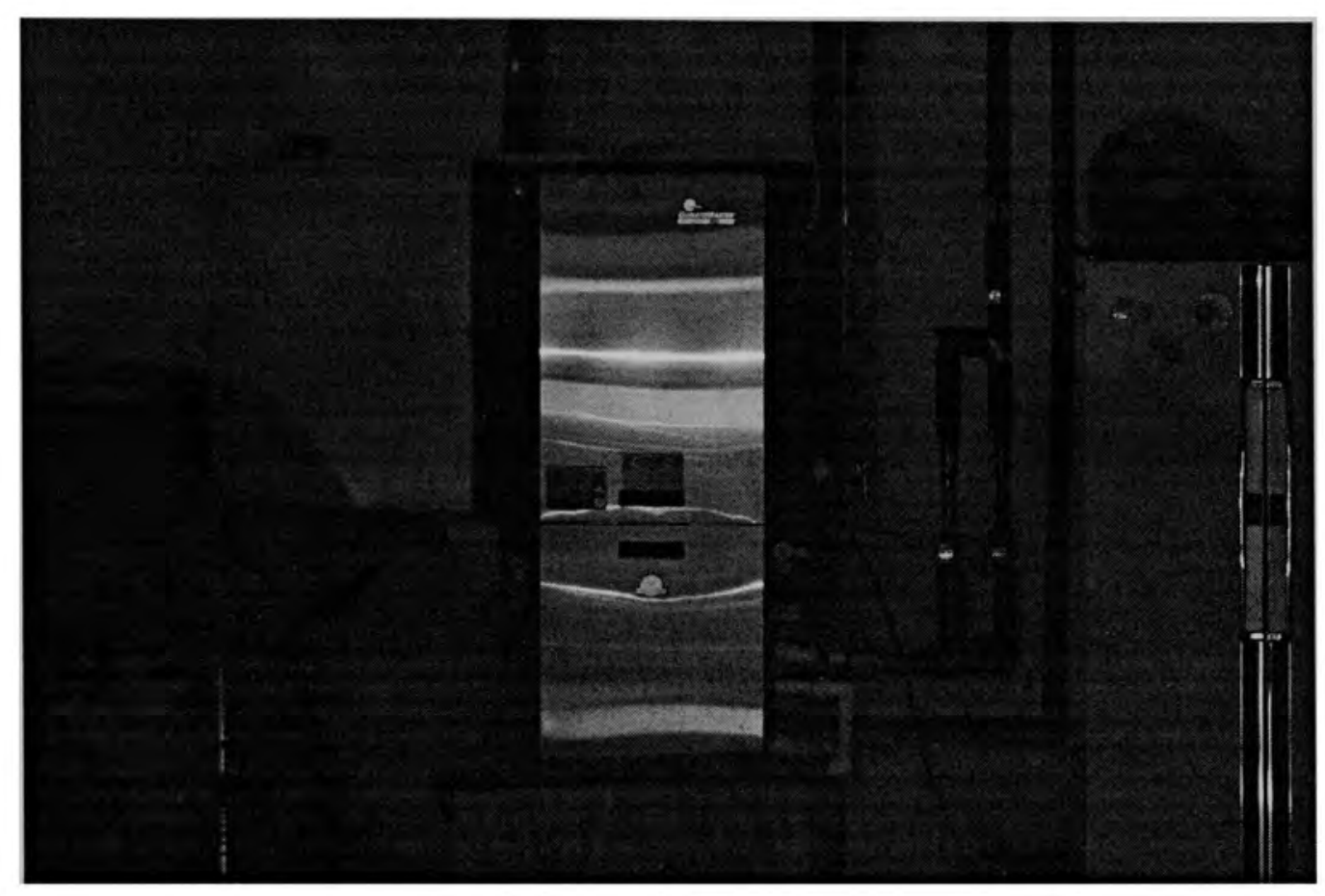

Figure 6 - The heat pump unit installed in the garage area

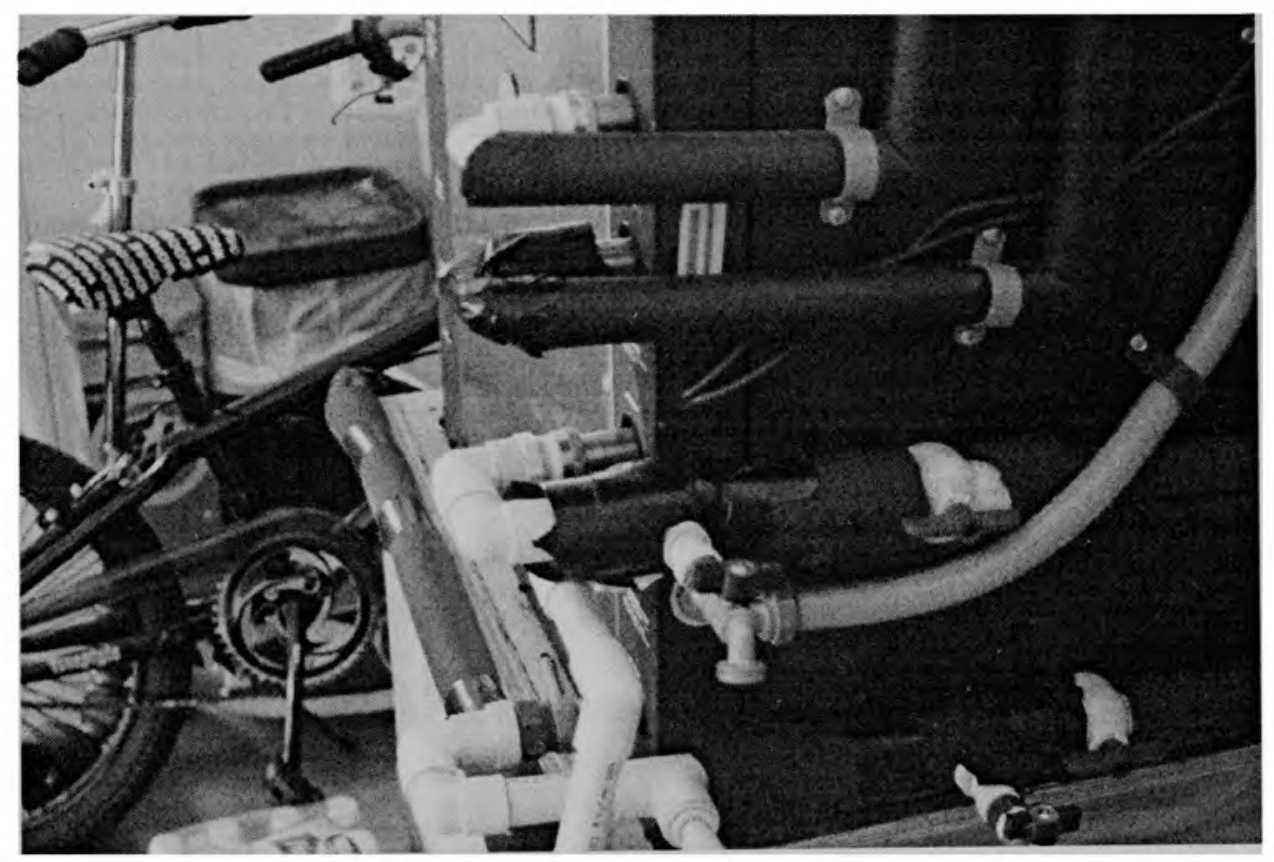

Figure 7 - The heat pump piping system 
Table 8 - General information about the building and GSHP system of First Residential Building

\begin{tabular}{|c|c|c|c|}
\hline City/Location & Capacity(Tons) & $\begin{array}{l}\text { System operation } \\
\text { start date }\end{array}$ & $\begin{array}{l}\text { Building type } \\
\text { (Residential, } \\
\text { Commercial, School, } \\
\text { etc) }\end{array}$ \\
\hline Holiday & 3 & Apr-10 & Residential \\
\hline $\begin{array}{l}\text { Building Floor } \\
\text { area, }\left[\mathrm{ft}^{2}\right]\end{array}$ & Number of stories & $\begin{array}{c}\text { Approximate } \\
\text { number of occupants }\end{array}$ & $\begin{array}{l}\text { Location type(Urban } \\
\text { center, Suburb, Rural) }\end{array}$ \\
\hline 1700 & 1 & 3 & Urban center \\
\hline \multirow{2}{*}{$\begin{array}{l}\text { Number of heat } \\
\text { pump units }\end{array}$} & \multicolumn{2}{|c|}{$\begin{array}{l}\text { Type of Loop (A:Vertical, Horizontal, } \\
\text { Spiral B:Hybrid GSHP, GSHP) }\end{array}$} & \multirow{2}{*}{$\begin{array}{l}\text { Number of } \\
\text { boreholes(for vertical } \\
\text { ground loops) }\end{array}$} \\
\hline & A & B & \\
\hline 1 & $\begin{array}{l}\text { Vertical-Open loop } \\
\quad(2 \text { wells })\end{array}$ & $\begin{array}{l}\text { GSHP + } \\
\text { Desuperheater }+ \\
\text { Electrical heater } \\
\quad \text { back up }\end{array}$ & - \\
\hline $\begin{array}{l}\text { Type of System } \\
\text { (Groundwater, } \\
\text { Ground-coupled, } \\
\text { Lake loop, etc) }\end{array}$ & $\begin{array}{l}\text { Type of incentive } \\
\text { (State, federal, } \\
\text { municipal, utility) }\end{array}$ & \multicolumn{2}{|c|}{$\begin{array}{l}\text { Could you provide us more information (i.e. } \\
\text { drawings, system specifications, monitoring } \\
\text { data, saving analysis) }\end{array}$} \\
\hline Ground water & $\begin{array}{l}\text { Utility(Progress } \\
\text { Energy Florida, } \\
\text { Inc. } \$ 150 \text { rebate) }\end{array}$ & \multicolumn{2}{|c|}{ No } \\
\hline
\end{tabular}

The owner was highly satisfied from his new HVAC system. Comfort level of the HVAC system has been increased a lot. House air temperature changes are smoother in comparison to conventional system. The air-cooled condenser of the old system was installed next to the bedroom and noise reduction because of elimination of outdoor 
equipment was highly desirable. Tap water was reported to be much warmer in the new system.

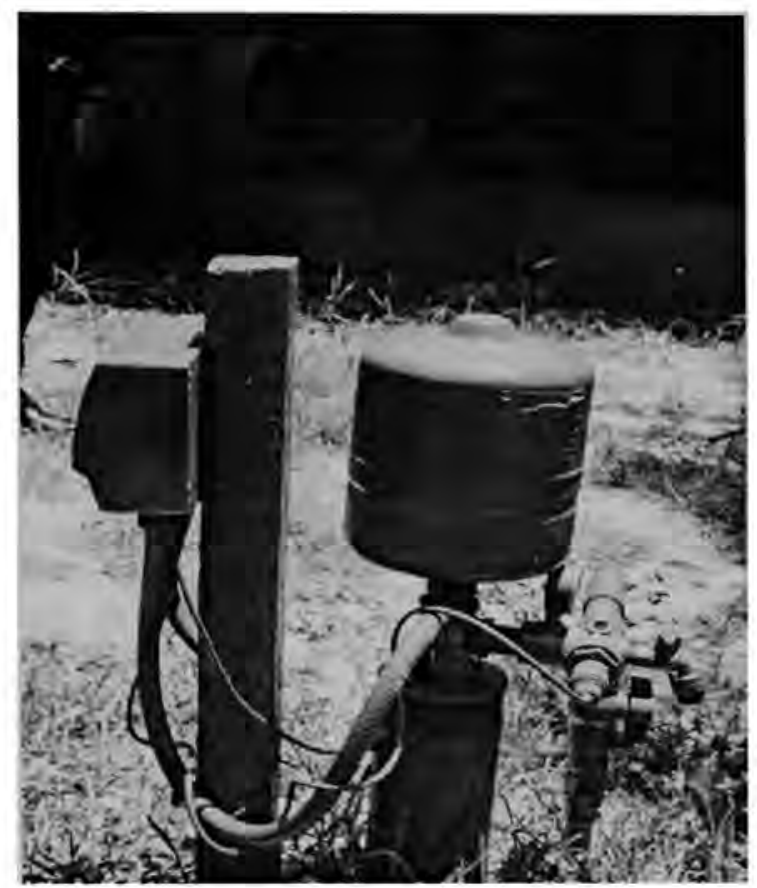

Figure 8 - Discharge and suction wells; green paining as an aesthetic idea.

The second house visited is a unique in the sense that it has employed different HVAC systems in one residential building. A $900 \mathrm{ft}$ horizontal slinky GSHP system has been installed 20 years ago. The heat rejection from the slinky loop had dried out the sand and had killed the grass. Owner has tried to keep the ground green and help the heat dissipation process from the ground by cultivating heat lover plants. To enhance the heat dissipation an $8 \mathrm{ft}$ deep pit was dug. There is a septic in the building's yard. The outlet of the septic was guided to the slinky loop area to increase the moisture content of the ground and the heat transfer rate to it. Seven years ago two open ground loops added to the system, two shallow wells $22 \mathrm{ft}$ deep and two deep wells $200 \mathrm{ft}$ deep. There is a manual valve that let the user switch between different ground loops. Initial costs of this 
system are as presented in Figure 13. Note that in this system wells were drilled and were not included in capital costs. Table 9 shows the general information about the building and GSHP system. Some details about this project are presented in Figures 10.

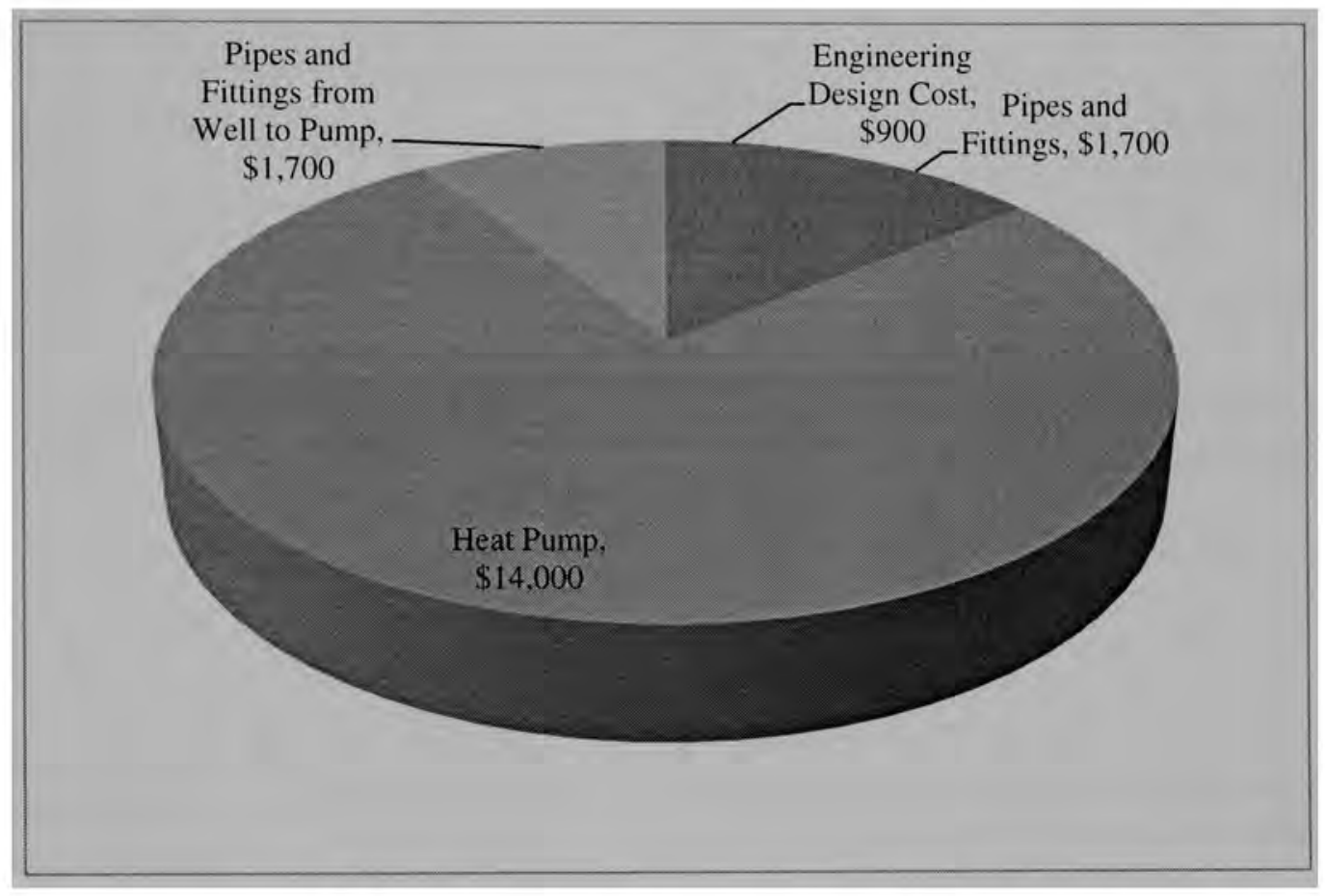

Figure 9 - Cost Breakdown of Second Residential Building

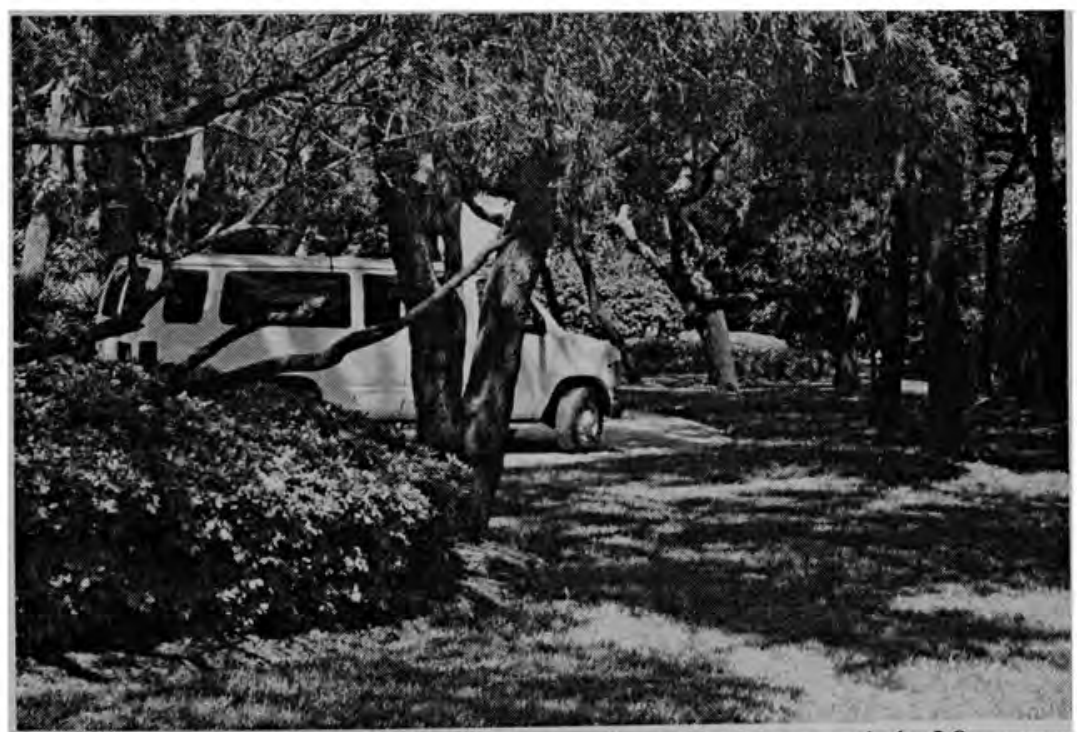

Figure 10 - The area that slinky loops were installed beneath it 20 years ago 
Table 9 - General information about the building and GSHP system of Second Residential Building

\begin{tabular}{|c|c|c|c|}
\hline City/Location & Capacity(Tons) & $\begin{array}{l}\text { System operation } \\
\text { start date }\end{array}$ & $\begin{array}{l}\text { Building type } \\
\text { (Residential, Commercial, } \\
\text { School, etc) }\end{array}$ \\
\hline Torpan Springs & $4+4.5$ & $\begin{array}{l}\text { a) } 20 \text { years ago } \\
\text { b) } 7 \text { years ago }\end{array}$ & Residential \\
\hline $\begin{array}{l}\text { Building Floor area, } \\
{\left[\mathrm{ft}^{2}\right]}\end{array}$ & Number of stories & $\begin{array}{l}\text { Approximate } \\
\text { number of } \\
\text { occupants }\end{array}$ & $\begin{array}{l}\text { Location type(Urban } \\
\text { center, Suburb, Rural) }\end{array}$ \\
\hline $\begin{array}{c}2725 \text { upstairs+ } \\
2600 \text { downstairs }\end{array}$ & 2 & 2 & $?$ \\
\hline \multirow[t]{2}{*}{$\begin{array}{l}\text { Number of heat pump } \\
\text { units }\end{array}$} & \multicolumn{2}{|c|}{$\begin{array}{l}\text { Type of Loop (A:Vertical, Horizontal, } \\
\text { Spiral }\end{array}$} & \multirow[t]{2}{*}{$\begin{array}{l}\text { Number of boreholes(for } \\
\text { vertical ground loops) }\end{array}$} \\
\hline & $\mathrm{A}$ & $\mathrm{B}$ & \\
\hline 2 & $\begin{array}{l}\text { a)Horizontal- } \\
\text { Slinky b)Vertical- } \\
\text { Open loop ( } 4 \text { wells- } \\
2 \text { pairs) }\end{array}$ & $\begin{array}{l}\text { GSHP+ Solar } \\
\text { water heater }\end{array}$ & - \\
\hline $\begin{array}{l}\text { Type of System } \\
\text { (Groundwater, } \\
\text { Ground-coupled, } \\
\text { Lake loop, etc) }\end{array}$ & $\begin{array}{l}\text { Type of incentive } \\
\text { (State, federal, } \\
\text { municipal, utility) }\end{array}$ & \multicolumn{2}{|c|}{$\begin{array}{l}\text { Could you provide us more information (i.e. } \\
\text { drawings, system specifications, monitoring } \\
\text { data, saving analysis) }\end{array}$} \\
\hline $\begin{array}{l}\text { a) Ground loop } \\
\text { b)Ground water }\end{array}$ & - & \multicolumn{2}{|r|}{ No } \\
\hline
\end{tabular}

There is another heat pump unit that employs a nickel-copper water to water heat exchanger to cool the condenser. The heat exchanger uses the open loop ground water as heat carrying fluid. The house is very close to the ocean. The high salt concentration in the ground water corrodes the heat exchanger. A titanium heat exchanger that is more resistant to the corrosion is about 10 times more expensive than nickel-copper heat exchanger. AquaCal is a local manufacturer that produces heat pumps that have pure titanium heat exchangers at their core. 
There is no significant electricity consumption saving, using geothermal systems in the house, in owner's opinion. He believes that the low efficiency of the old rolling compressors is the reason of negligible difference between his house's electricity consumption and a similar house with conventional HVAC system.

Cost information regarding systems 3 to 6 are given in Figure 11. All of the systems were residential applications, using groundwater for heat exchanger.

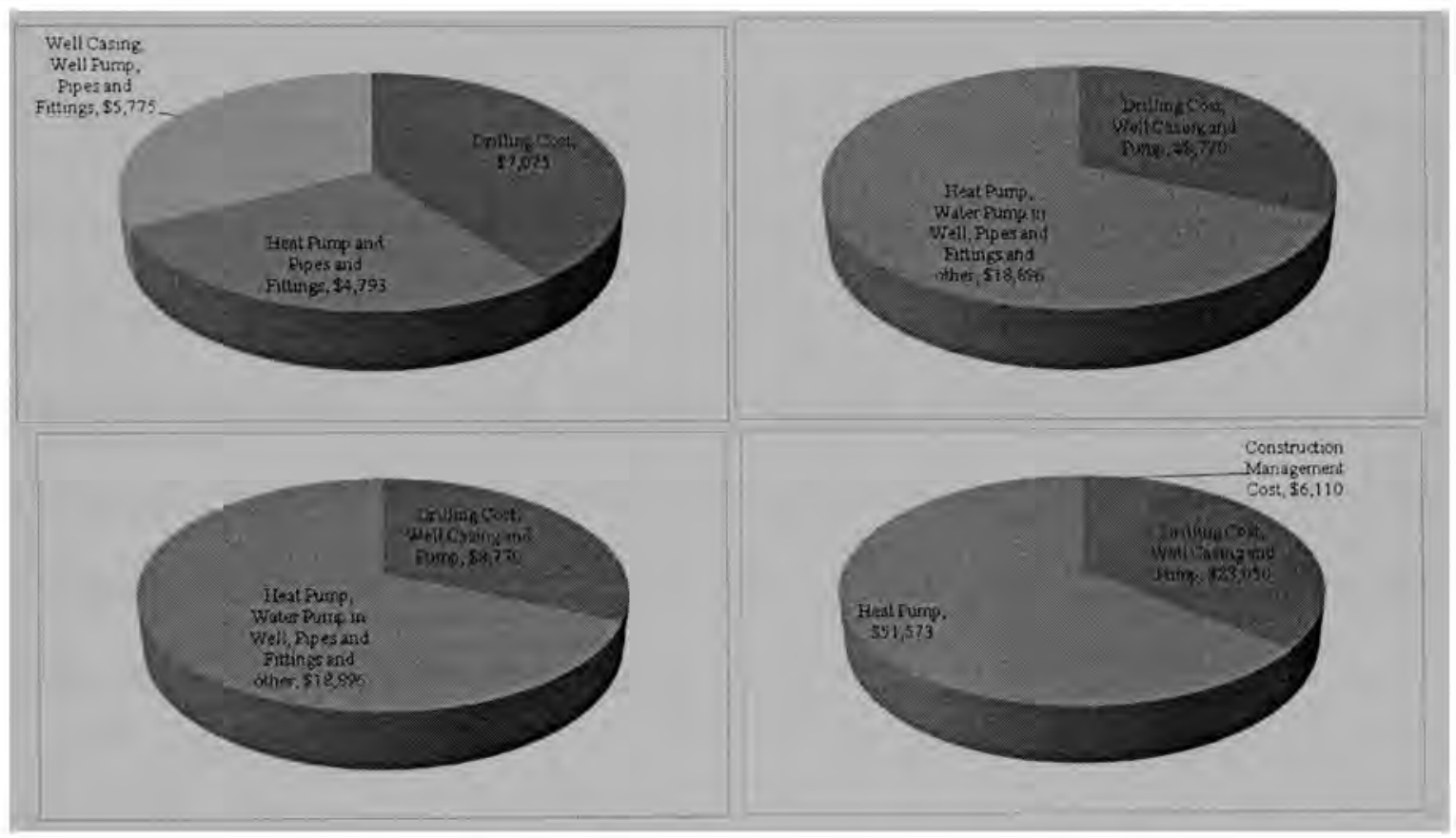

Figure 11 - Cost information regarding systems 3 to 6

\subsection{2 - Trip to Pensacola and Information Gathered}

The Springhill Suites has been located in Pensacola Beach. The hotel consists of 117 rooms with 80000 square $\mathrm{ft}$ area. . It has been constructed in 2002. The HVAC system is a 300 tons hybrid GSHP. The system features a 150-ton closed-loop evaporative fluid cooler. The loop field is set up in parallel with the 150-ton fluid cooler, which offers 
considerable heat rejection control and redundancy. The primary domestic water heaters are three each, 35 tons and five horsepower water-to-water geothermal heat pumps. All pool and spa heating is provided by geothermal heat pumps. In addition, over 300 tons of room unitary, ducted geothermal heat pumps are used in guest suites and to serve all other conditioned areas of the hotel. The ground loop construction has been started at December 2001 and it took one and a half month to construct. The whole GSHP system construction took 7 months and the system has been operated at the early July 2002 .

The ground loop is composed of 4 circuits with 24 boreholes in each circuit. Each borehole has a $200 \mathrm{ft}$ depth and 1 in diameter U-tube pipe. Supply and return of each circuit are 4 inches pipes. Main loop pipe has an 8 inches diameter. Polyethylene pipes have been used in the whole ground loop and connected branches piping system. There are two $40 \mathrm{HP}$ pumps in the main loop that one of them is standby pump. The cost breakdown of the cost of this hotel is as given in Figure 12. Some details about the project are expressed through Figures 13 to 16. 


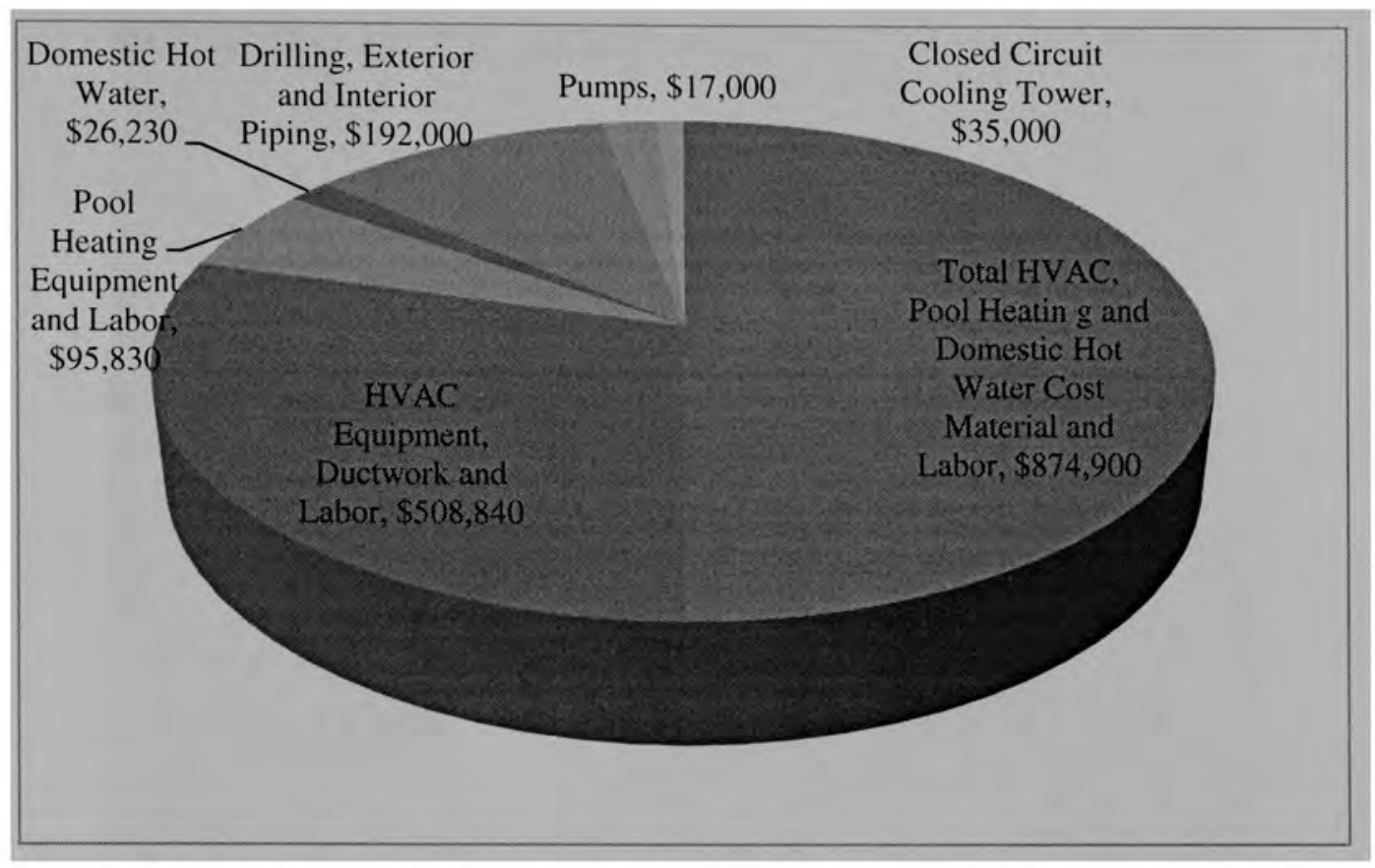

Figure 12 - Cost Breakdown of Springhill Suites HVAC System

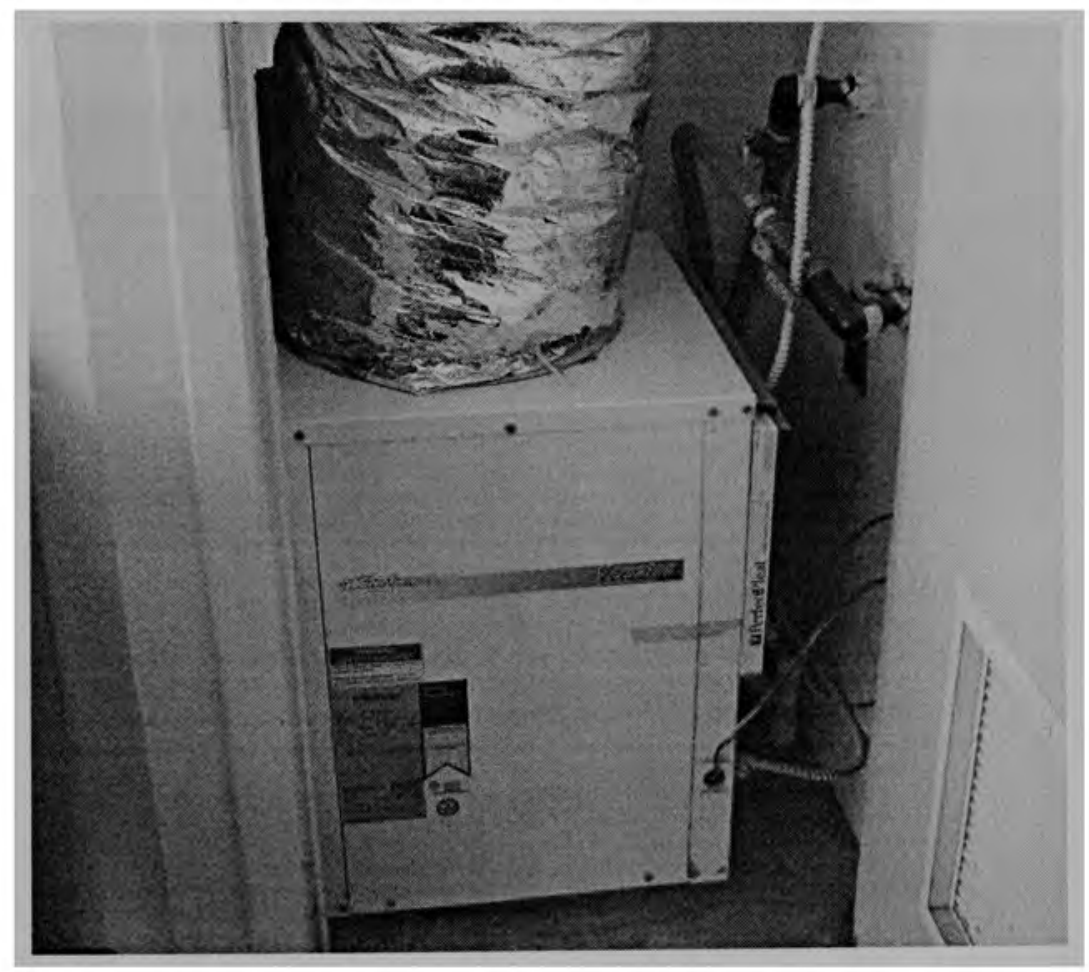

Figure 13 - Springhill Suites Indoor heat pump unit 


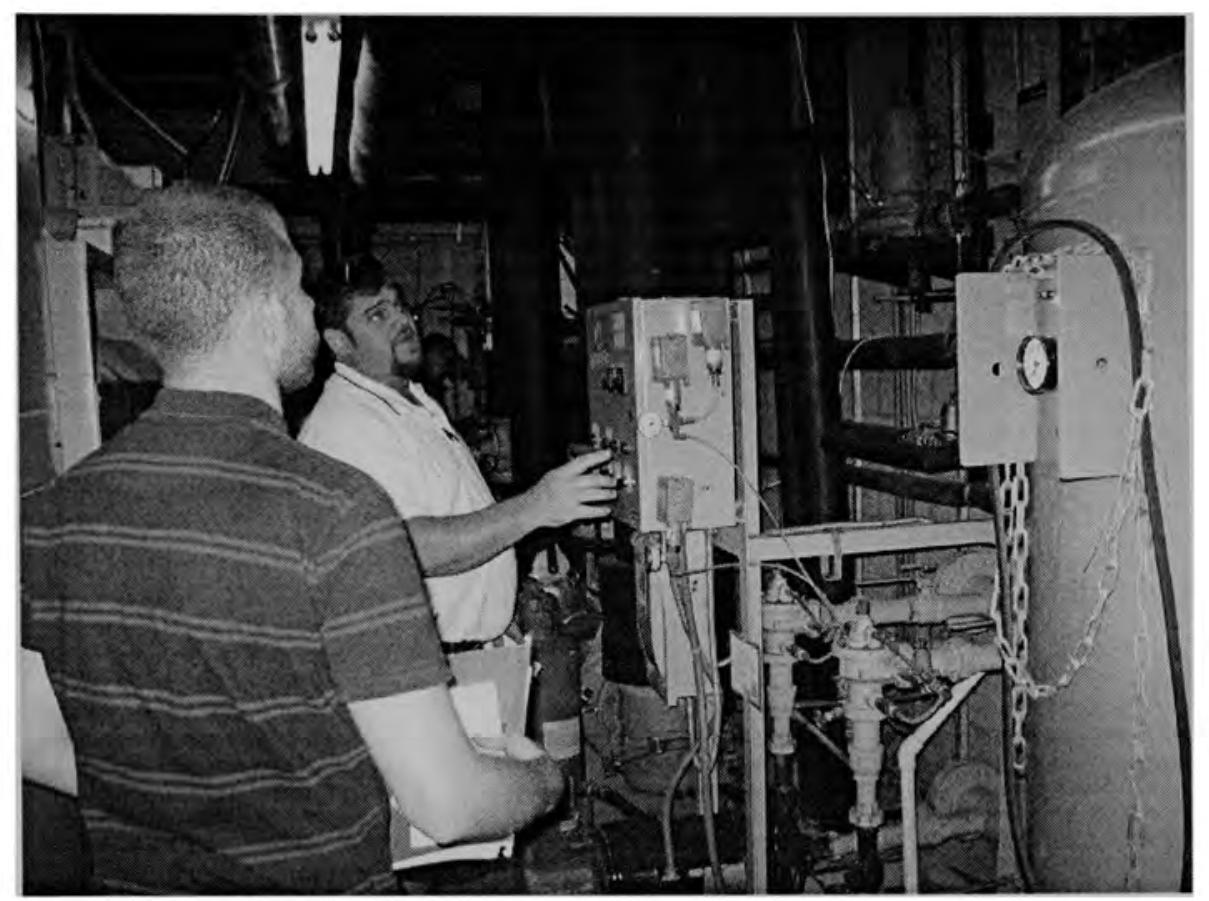

Figure 14 - Springhill Suites Mechanical room

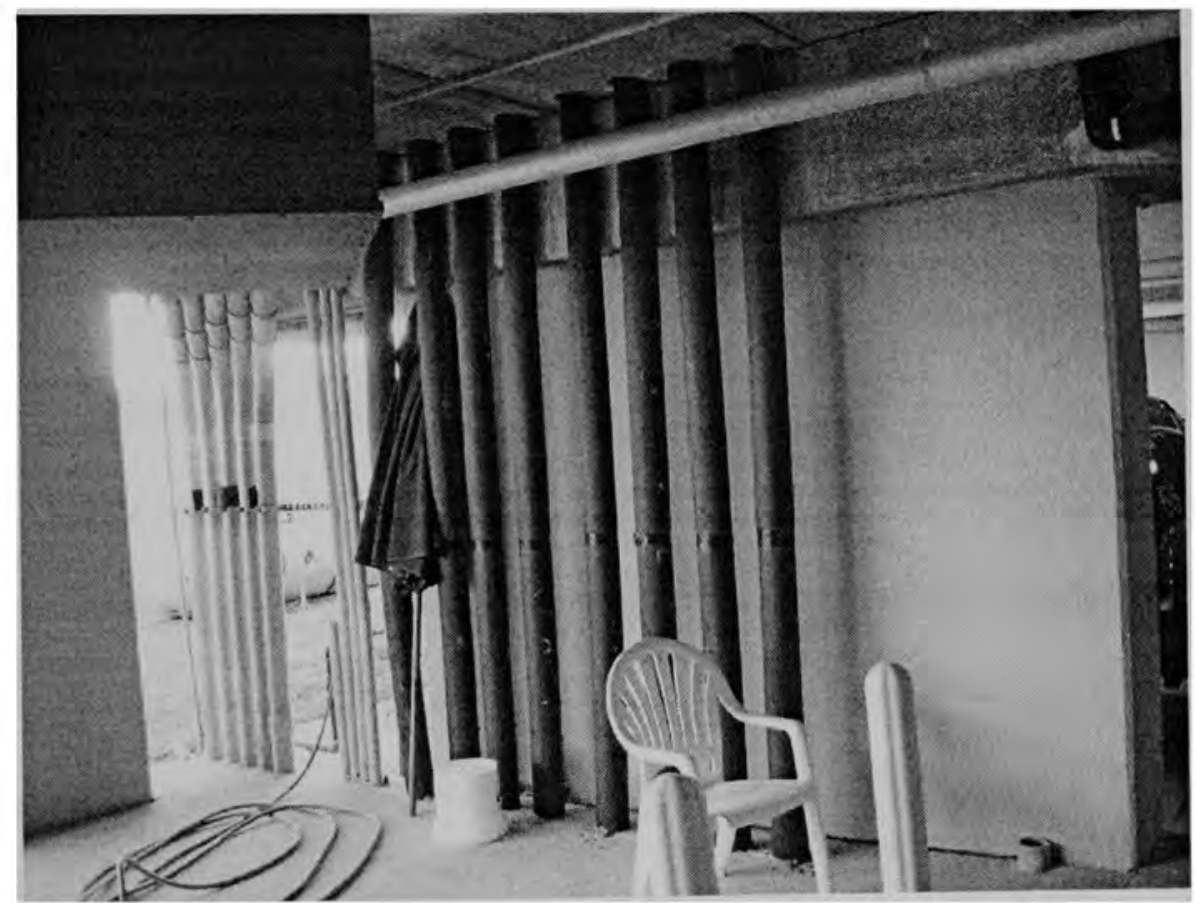

Figure 15 - Springhill Suites Supply and return pipes 


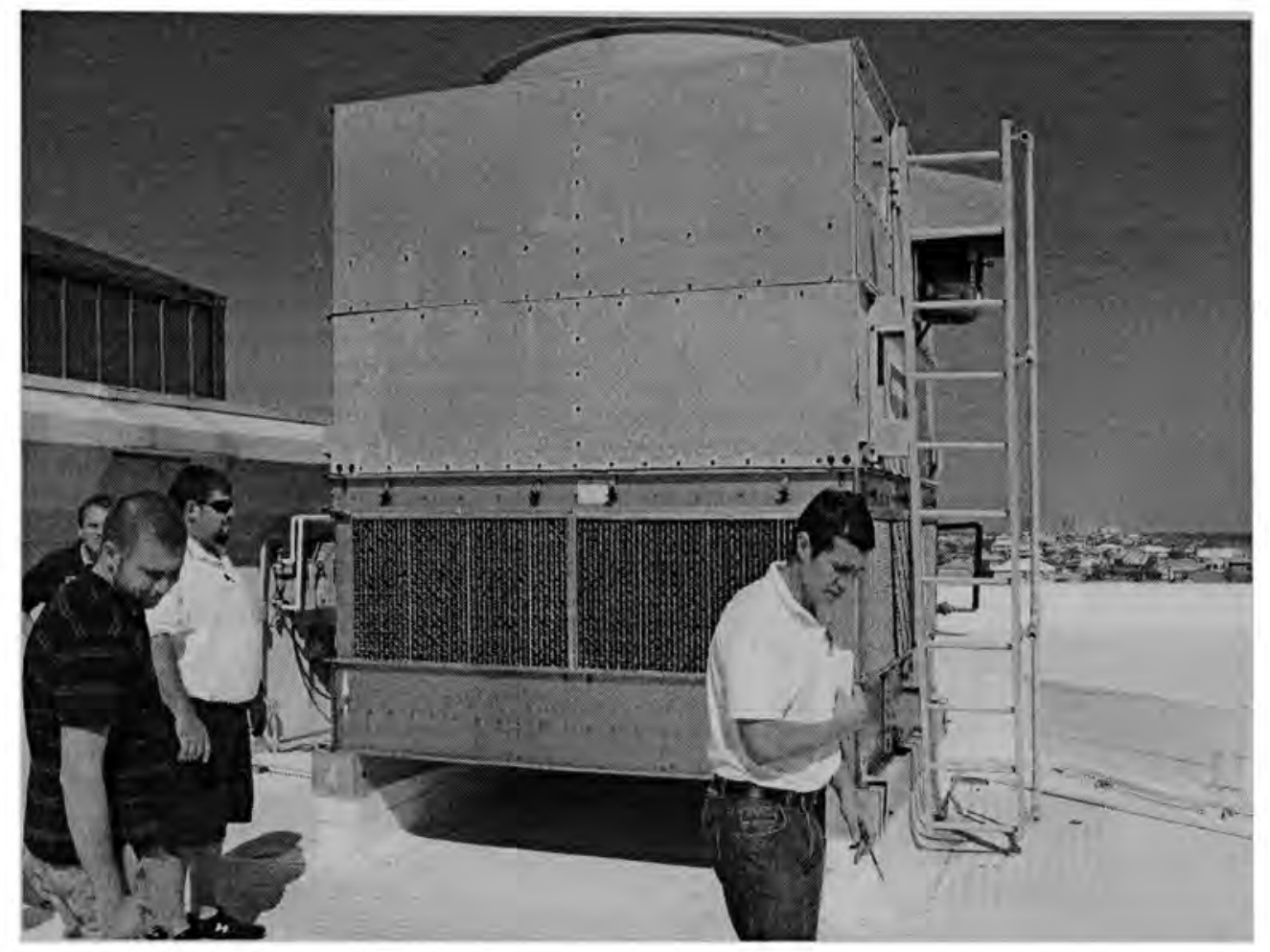

Figure 16 - Springhill Suites Cooling tower

Grand Marlin Restaurant that has been located at Pensacola beach is a 13,600 square ft facility overlooking the sea. The HVAC system used for this building is a 129 ton GSHP system. The ground loop is composed of 5 circuits with 28 boreholes in each circuit. Each borehole has a $300 \mathrm{ft}$ depth and $3 / 4$ in diameter U-tube pipe. Supply and return of each circuit are 4 inches pipes. Main loop pipe has an 8 inches diameter. Polyethylene pipes have been used in the whole ground loop and connected branches piping system. There are two $10 \mathrm{HP}$ pumps in the main loop that one of them is standby pump. Cost of the GSHP project, as obtained from contractors is shown in Figure 17. 


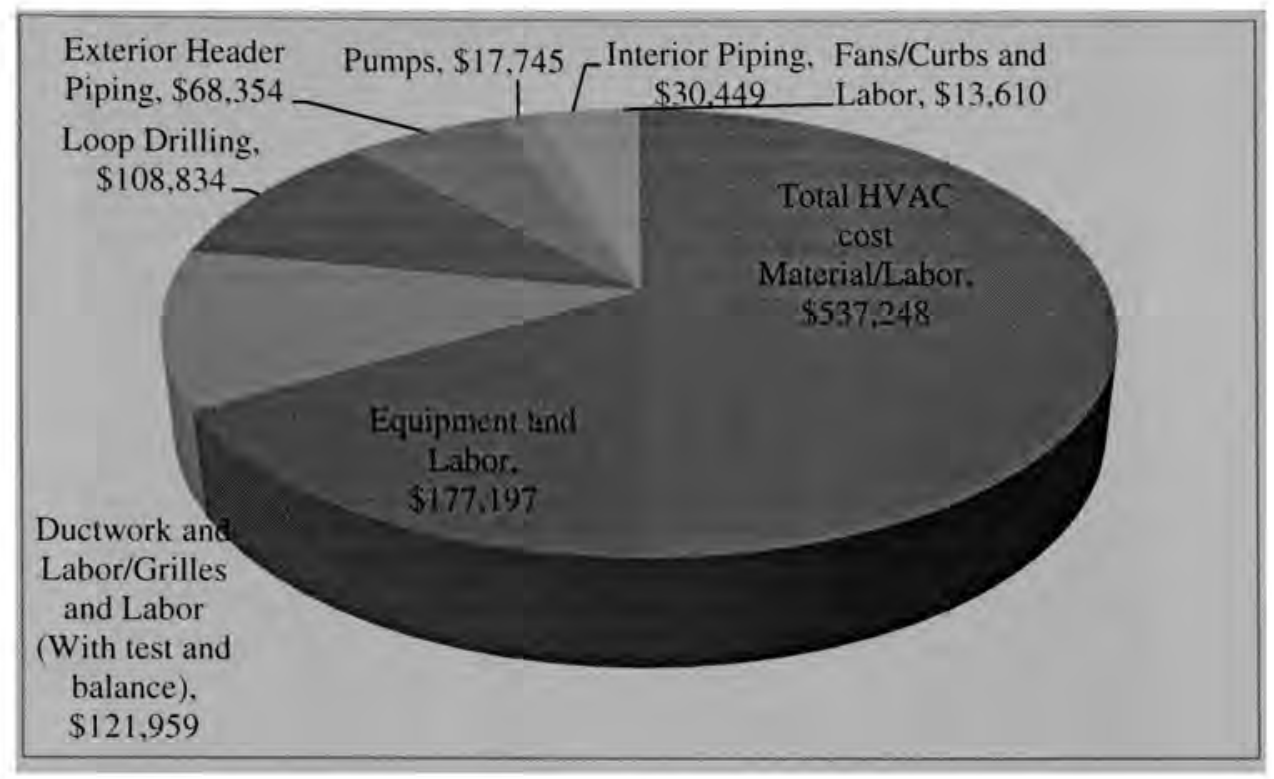

Figure 17 - Cost Breakdown of Grand Marlin Restaurant HVAC System

There is no domestic water heating system using the ground loop in the facility. Mechanical contractor of the project has been changed once by the owner because of the unsatisfactory performance. The initial contractor built two times more loop than necessary so owners were very keen on reducing any cost possible. For this reason, a geothermal domestic water heating system, which could have worked very efficiently, has been abandoned. The ground loop construction has been started at May 2009. The whole GSHP system construction took about one year and the system has been operated at April 2010. Figures 18 and 19 are from the outside and mechanical room of Grand Marlin Restaurant, respectively. 


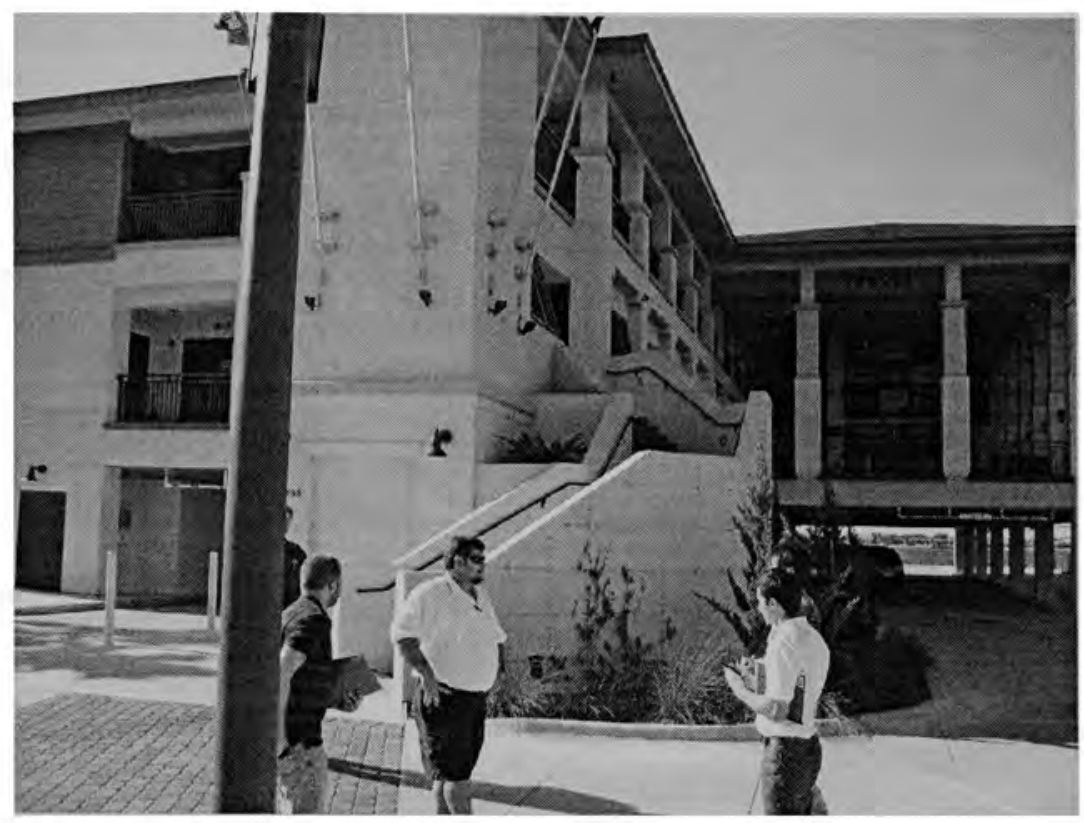

Figure 18 - Grand Marlin Restaurant

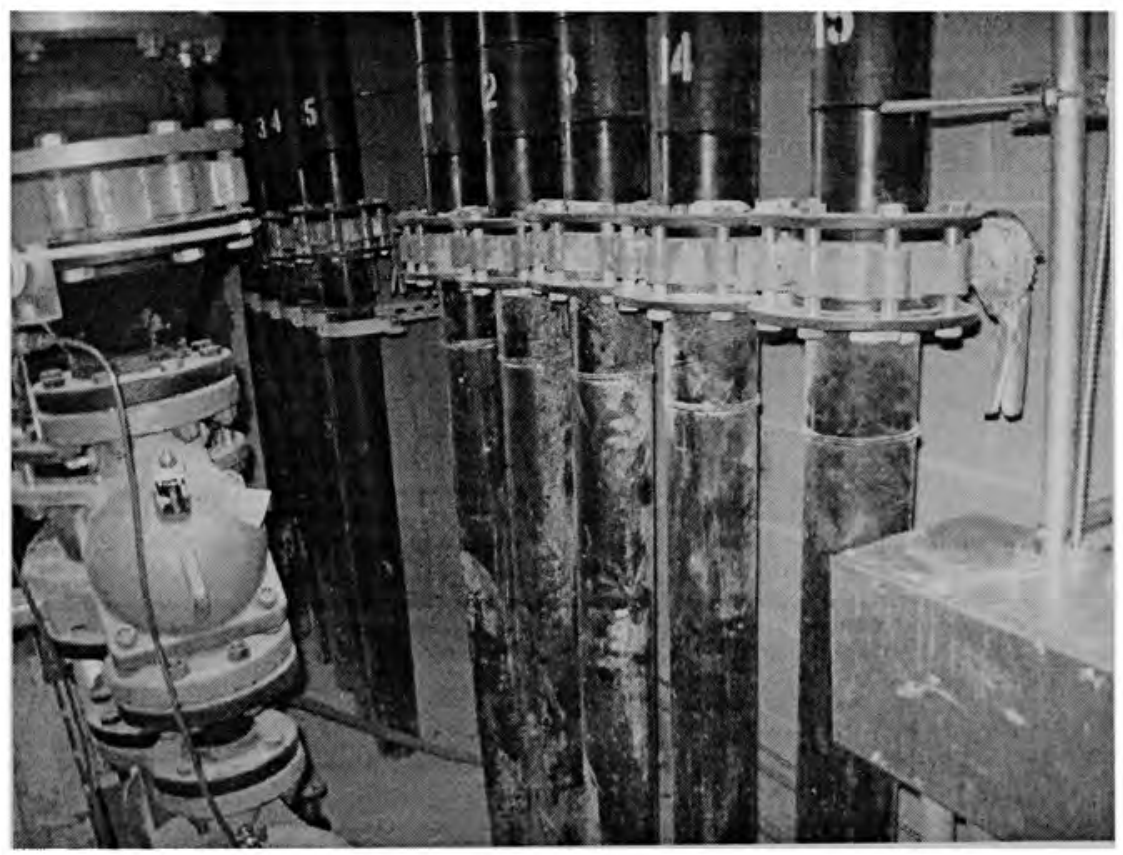

Figure 19 - Grand Marlin Restaurant-Supply and return pipes 
Rodney Rich Building is a commercial building in downtown Pensacola, built in 2010 and the system operation starts 3 months ago. At the building construction, energy efficient materials like ICF walls and Low-E windows have been used. Building is one storey having an area of 4250 square ft. The HVAC system of this building consists of a 13 ton GSHP system, with two 6 ton units and one 1 ton unit. The GSHP system utilizes a vertical loop, which is composed of 14 boreholes reaching a depth of 300 feet. Cost information of Rodney Rich Building is as presented in Figure 20.

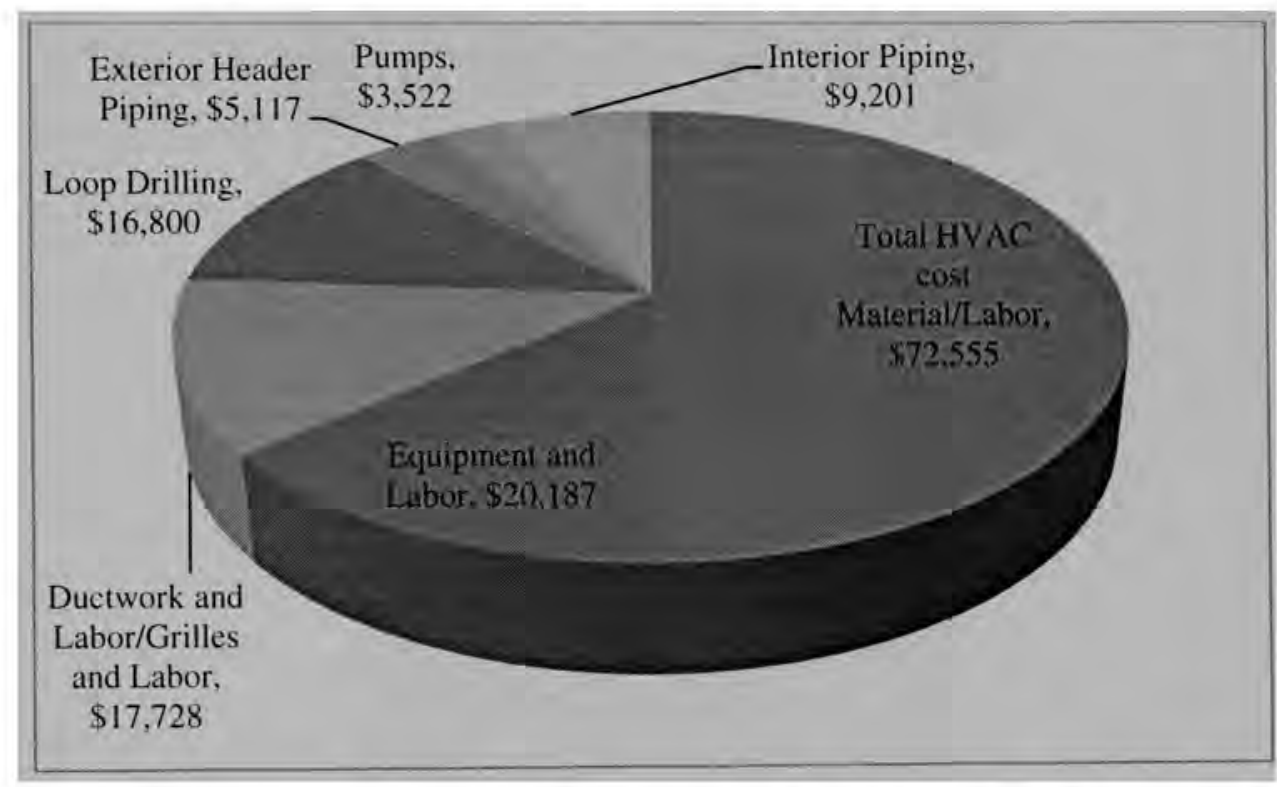

Figure 20 - Cost Breakdown of Rodney Rich Building HVAC System

In the Rodney Rich building, two 6 ton units were responsible from the main heating and cooling of the building while the one ton unit was used for a computer server system. Two 6 ton units are located in the attic and there was no access to them at the time. These units have variable speed fans and dual speed compressors. There are two $1 \mathrm{HP}$ pumps in the main loop that one of them is standby pump. Several details regarding this building are given in Figures 21 to 23 . 


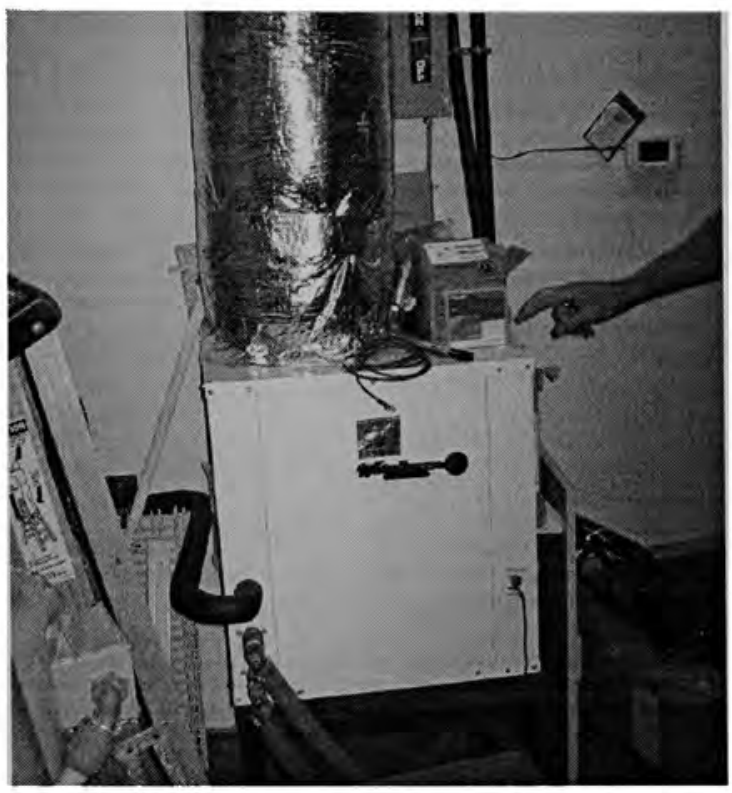

Figure 21 - Rodney Rich building 1 ton unit

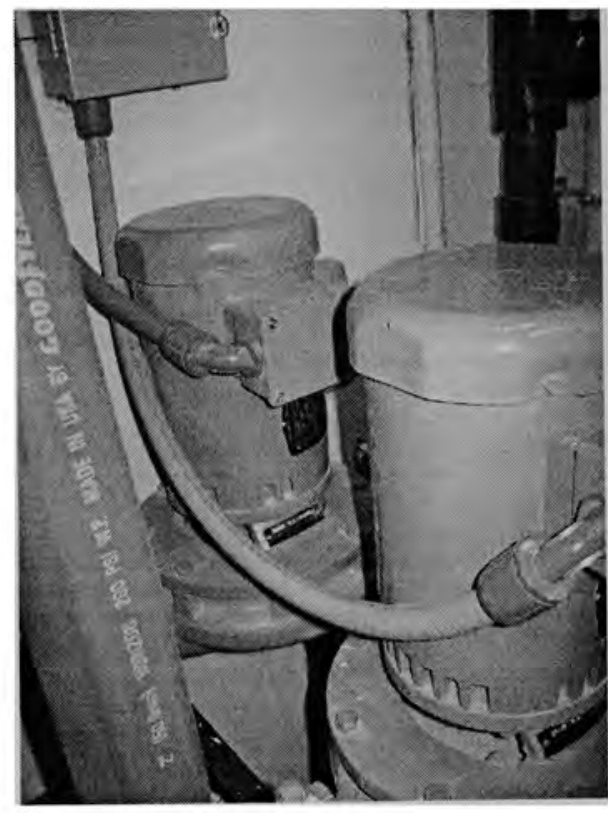

Figure 22 - Rodney Rich building Main loop pumps 


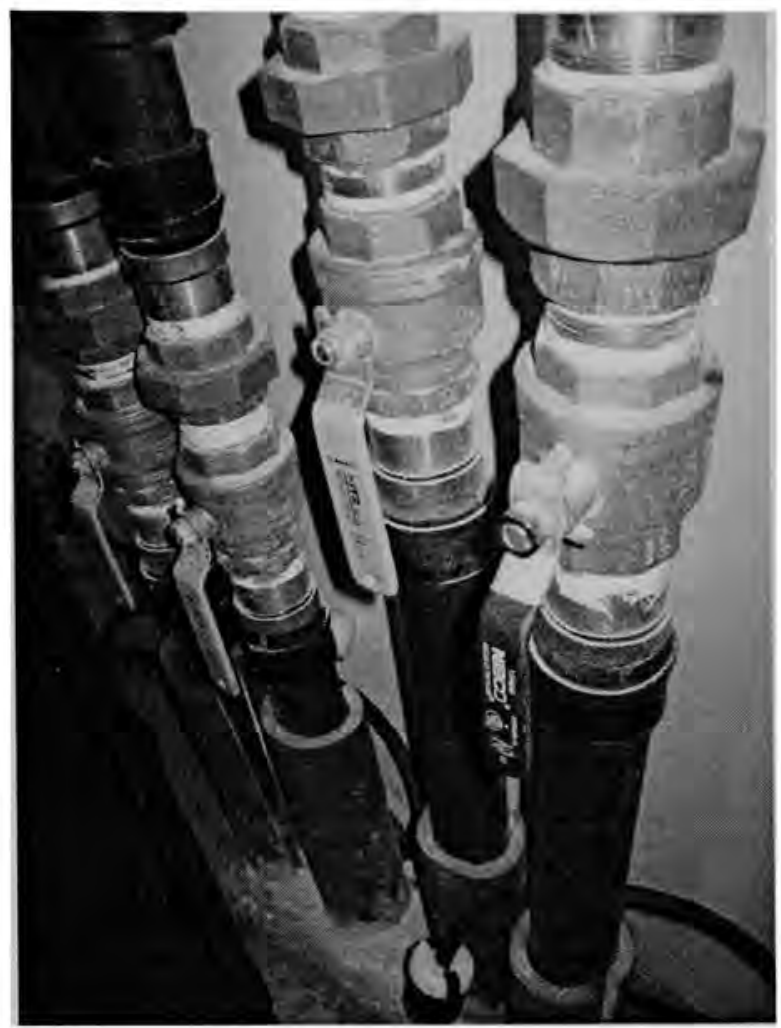

Figure 23 - Rodney Rich building-Supply and return pipes

\section{2 - General Observations about GSHP Systems}

During the trips made to Pensacola and Tampa, opinions of those who are long in the GSHP industry have been noted down. Several questions have been asked to learn the current situation of GSHP systems, their past and future and problems faced before and after the installation of those systems. The individuals were mainly contractors who have been designing and installing GSHP systems or people who are in energy distribution companies. The main points from these conversations can be summarized and listed as below:

- There is a serious conflict of priority and lack of integration between the owners, or operators of the buildings and constructors. Professionals underlined the fact 
that constructors always strive to finish the job in the cheapest way possible, without considering the long term functionality effects. Due to this fact, they avoid the GSHP systems as they usually have initial costs. It was stated that, upon completion of building, the owners feel that the utility or maintenance costs are high but at that time it is too late or too costly to go back to modify the design. However, if there was a better communication and transfer of information between the contractor and the end user, it would be much easier to reduce the periodic costs and energy consumption, and therefore, life-cycle costs.

- The GSHP systems are gaining more recognition and more people are getting into the industry. Even though, this is a positive incident, it may easily cause unfavorable situations. Since the initial design of GSHP systems are more critical than other HVAC alternatives, mistakes can be more costly and difficult to change. Many contractors state that this is creating higher initial costs and thus, increasing the payback period of the systems. Also, unsuccessful designs are creating a negative word of mouth about this relatively new technology.

- Another important point made by professionals is that lack of standards and supervision. It was pointed out that currently, there are not sufficient design guidelines and codes that can prevent deficient designs and installations. Professionals underlined that properly enforced codes will improve the quality and performance of the systems and help this technology used more widely.

- Also, many professionals stressed that the GSHP systems should be advertised more and marketing strategies should be improved. For this rebates and tax 
credits can be increased as it for the benefit of both users and energy providing agencies. 


\section{4- Life-Cycle Cost Analysis and Sensitivity Analysis}

\section{1 - Methodology}

Life-cycle cost analysis takes into account every cost item that is possible during the expected use type of a system. After the cost items are fully defined, they are brought to a comparable single value based on the used interest rate used. This makes it possible to compare similar alternatives economically and select the most feasible one. This cost can be represented as annuities, as a total sum at the end of project life time. More often, life-cycle costs are described as a sum at today's value using a realistic inflation rate. This method, known as net present value (NPV), is highly utilized while making engineering decisions.

The study focuses on making life-cycle cost analysis of a ground source heat pump systems and assessing the cost effectiveness of the GSHP systems with respect to fluctuations in the cost items. The cost effectiveness has been compared with a conventional HVAC system, which is typically used in hot and humid climate regions. For this purpose, initially, all cost items that occur during the life time of GSHP systems and the selected conventional system has been modeled.

The cost components of systems included initial (capital) costs, annual energy costs, annual maintenance costs and periodic replacement costs. The costs for the conventional system have been taken from literature, RS Means (2010) and from the collected data whenever possible. For the initial costs of GSHP systems, a cost assembly 
has been created and other cost items have been taken from literature. Annual energy costs for both systems have been calculated with the aid of eQUEST energy simulation program.

After the definition of the cost items, this has been applied to a theoretical building. The introduced methodology for making a life-cycle cost analysis and sensitivity analysis has been carried out. The two systems are compared as a basis to show a simplified procedure for conducting comparative life-cycle cost analysis. A typical single story family house has been used for demonstrating the process. This dwelling is thought to be located in Tampa, FL and all weather and geographical data is modeled according the selected location. The size of the HVAC systems was determined from the energy simulation tool eQUEST. This free computer tool was also used for the detailed comparative life-cycle cost analysis and sensitivity analysis.

Since life-cycle cost analysis is usually a static approach and do not include variable items, these concepts are introduced based on the studies, cost alternations, electricity prices. The possible range of the cost variable has been attained and a sensitivity analysis has been conducted. During this study, possible variations in electricity costs, initial cost components and maintenance costs have been studied. 


\section{2 - General Parameters for Life-Cycle Cost Study}

The general parameters used for life cycle cost study are those that are independent of the system type. These parameters can be listed as electricity costs, inflation rates, the construction cost index percentages used for updating any literature data to today's date.

The electricity prices, which were steadier in the past, are following an increasing trend in the recent years. The electricity prices are particularly important as they are the main source of savings for a GSHP system. The information regarding the electricity prices were acquired from U.S. Energy Administration website. For the state of Florida, the electricity cost per $\mathrm{kWh}$ is as shown in Figure 24. According to the website, it is projected that the increasing trend in the electricity will diminish in future. For the calculations, the base electricity price was taken as $\$ 0.107 / \mathrm{kWh}$.

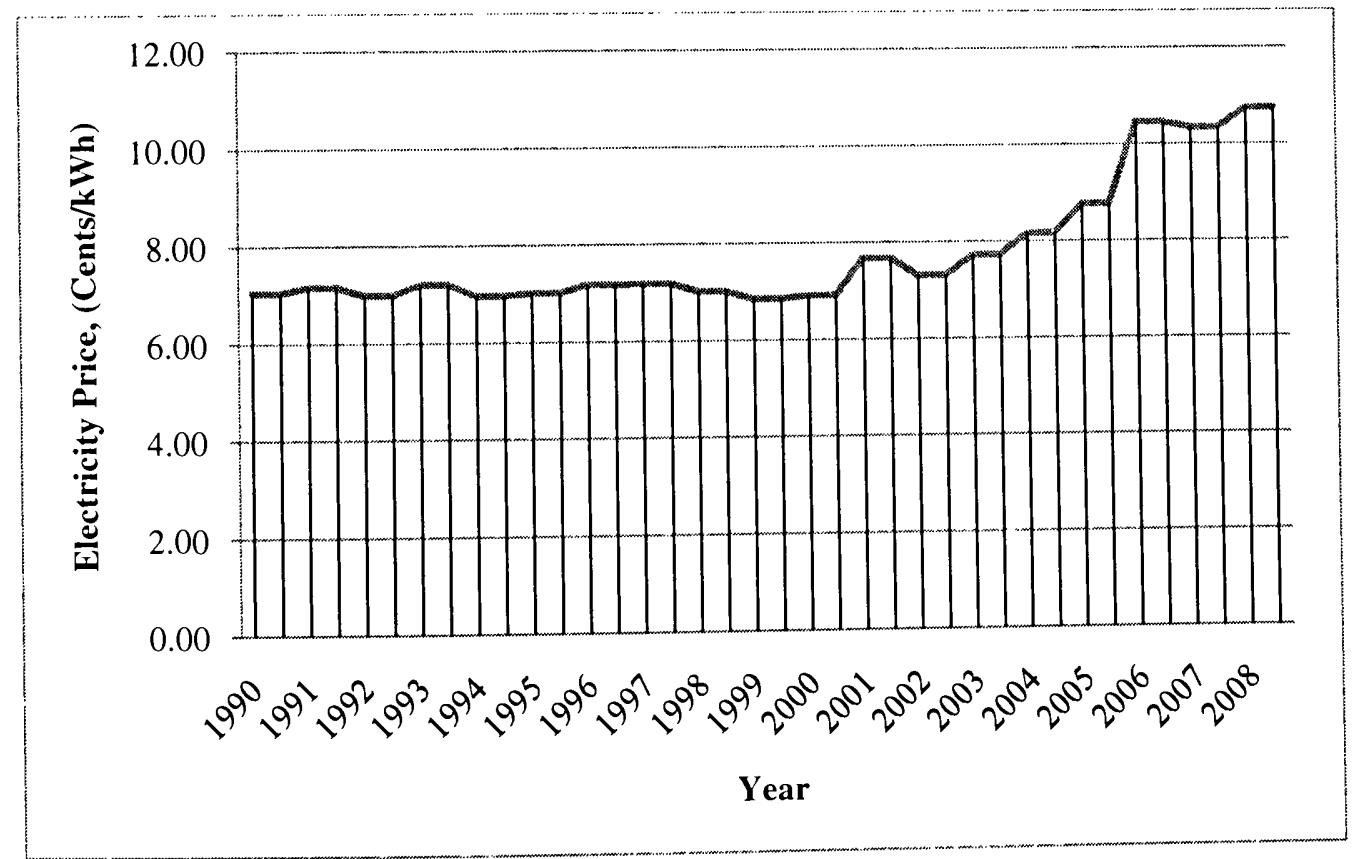

Figure 24 - Electricity prices by year 
Another important factor that is needed for life cycle cost calculations is the discount rate. The inflation rates from 1993 to 2009 as taken from U.S. Bureau of Labor Statistics are shown in Figure 25. For this study, discount rate was taken 3\%.

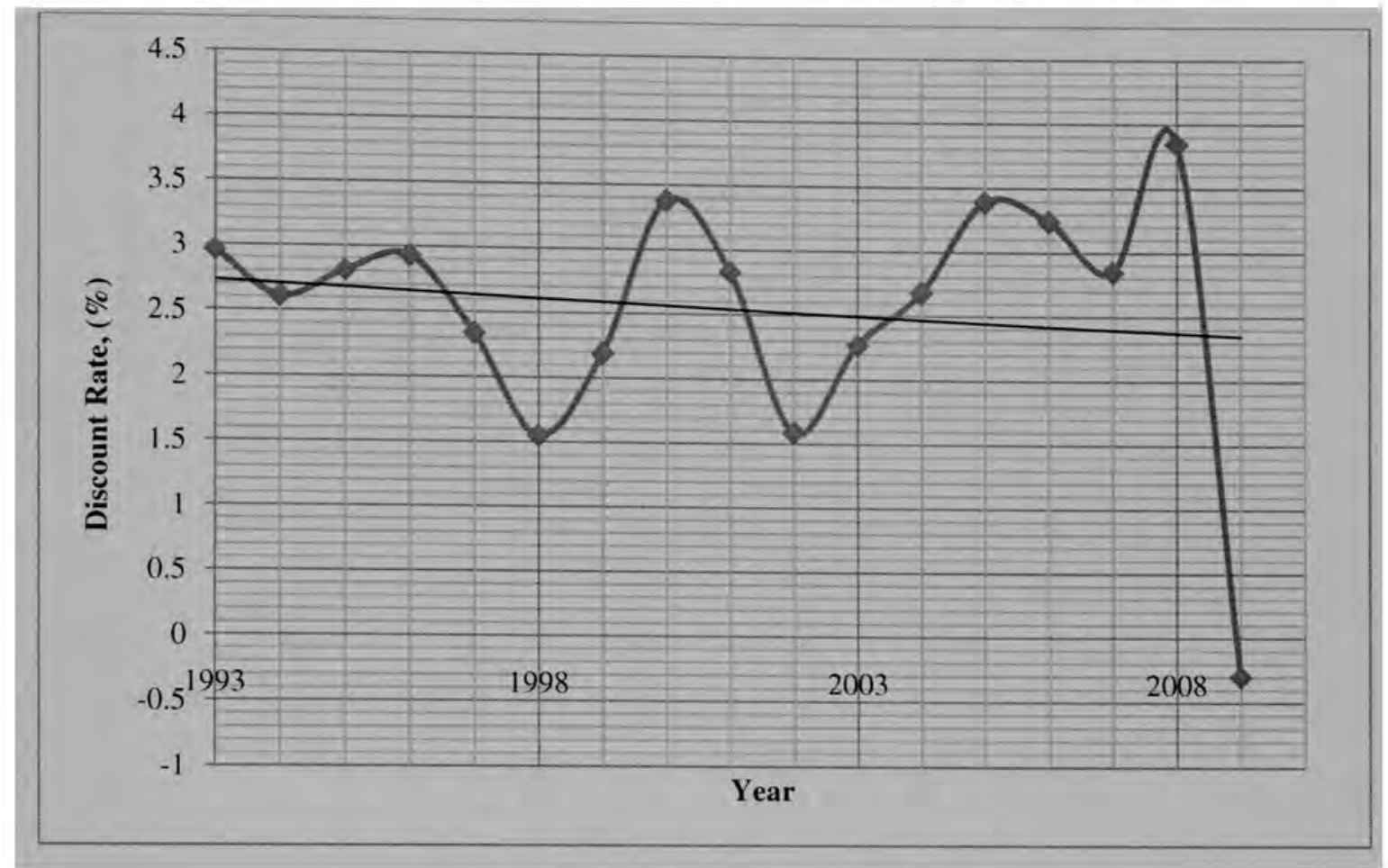

Figure 25 - Discount rates from 1993 to 2009

Especially on calculation of initial costs of certain GSHP systems, the cost information is taken from the literature. For updating the cost information in the literature to year 2010, the construction cost index, released by Engineering News and Record is utilized. The cost index for years 1980 to 2010 is shown in Figure 26. 


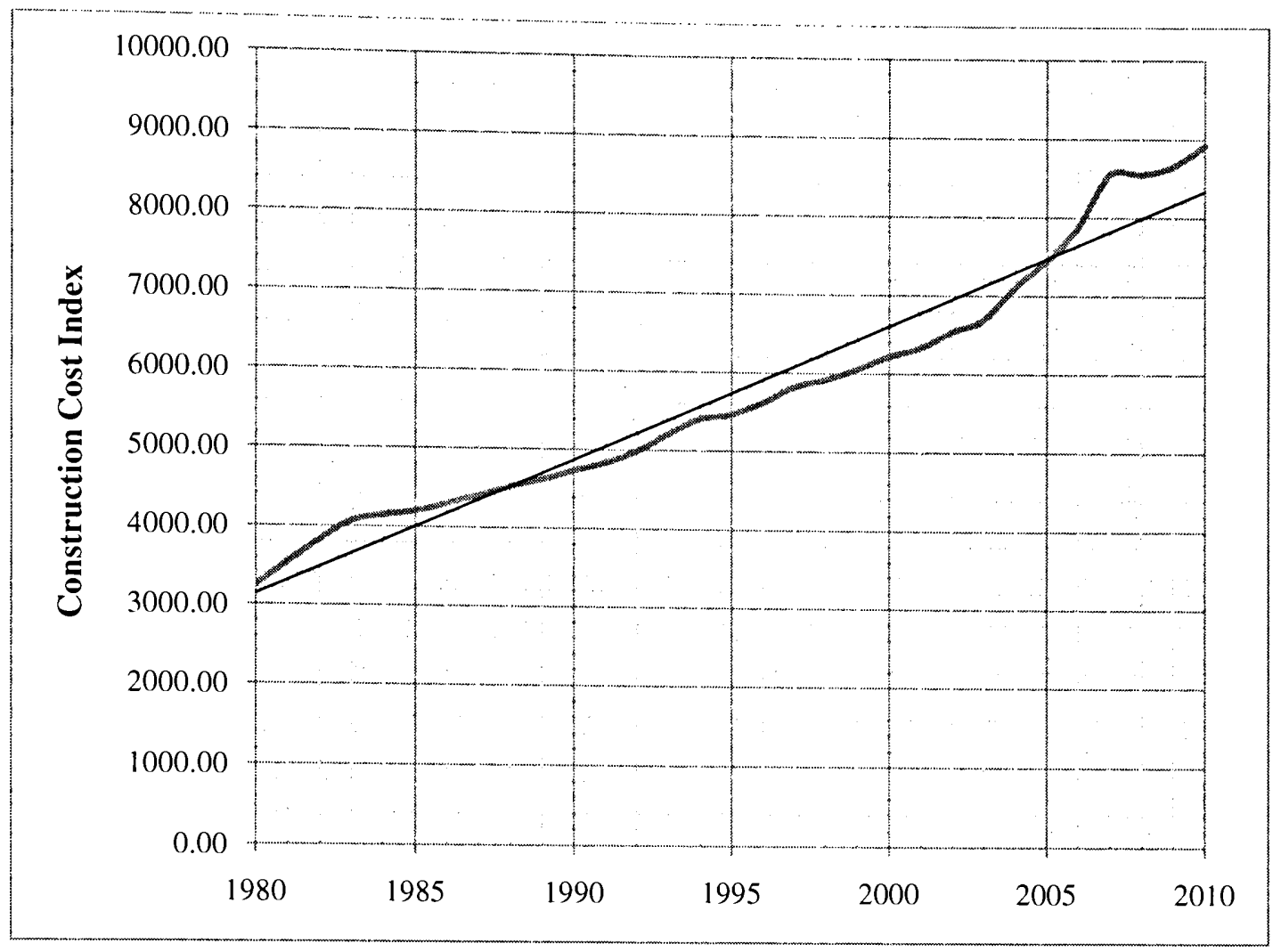

Figure 26 - Construction Cost Index from 1980 to 2010

\section{3 - Life-Cycle Cost Analysis Items for GSHP System}

\subsection{1 - Initial Costs}

\section{Initial Costs of GSHP systems}

All GSHP systems use the ground as a heat source or heat sink. However, the means of using the ground (ground heat exchanger) can show a variation. Vertical closed loop systems, horizontal closed loop systems and open loop systems are the most common systems. All of the systems are the same excluding ground heat exchanger. While calculating these costs, the data available on the literature and cost information 
gathered during the trips have been used. The data used have been updated to 2010 values using the construction cost index.

The cost of vertical heat exchanger includes the auger drilling cost, high density polyethylene pipe material and installation cost, and grouting costs. These costs are presented in Table 10. In this subassembly, the cost of drilling can show a significant variation depending on the type of soil. The values obtained from the study done by Kavanaugh et al. (1995) for residential applications, were updated and the cost was calculated as $\$ 3334$ per ton capacity of the system. For commercial applications, data gathered from trips was presented in Figure 27 for per ton capacity of system. The average price of vertical closed loop per ton was calculated as $\$ 6,332$ for commercial applications.

Table 10 - Initial costs for vertical closed loop systems

\begin{tabular}{|c|c|c|}
\hline $\begin{array}{c}\text { Cost } \\
\text { Component }\end{array}$ & Definition of Cost Items & Unit \\
\hline $\begin{array}{l}\text { Engineering } \\
\text { Design }\end{array}$ & $\begin{array}{l}\text { Modeled as a percentage of total construction cost, } \\
\text { includes civil or mechanical design cost }\end{array}$ & $\$$ \\
\hline Borehole drilling & $\begin{array}{l}\text { Depth of the borehole and type of soil determines the } \\
\text { type of equipment used (Main component is augers, } \\
\text { rented daily) }\end{array}$ & $\$ /$ day \\
\hline Ground loop & $\begin{array}{l}\text { The polyethylene pipe used for ground loop, depends on } \\
\text { capacity requirements }\end{array}$ & $\$ / \mathrm{ft}$ \\
\hline $\begin{array}{l}\text { Loop Pump } \\
\text { System }\end{array}$ & $\begin{array}{l}\text { The pump used circulation of heat exchange fluid inside } \\
\text { the loop, the capacity of the system determines }\end{array}$ & \$/each \\
\hline $\begin{array}{l}\text { Water Pump } \\
\text { controls and } \\
\text { valves }\end{array}$ & Controls and valves associated with the water pump & \$/each \\
\hline $\begin{array}{l}\text { Pipes and } \\
\text { Fittings }\end{array}$ & Includes all pipes and fitting to and from loop & $\$ / \mathrm{ft}$ \\
\hline Heat Pump & $\begin{array}{c}\text { Depends on the capacity required, size and location of } \\
\text { the building }\end{array}$ & \$/each \\
\hline
\end{tabular}




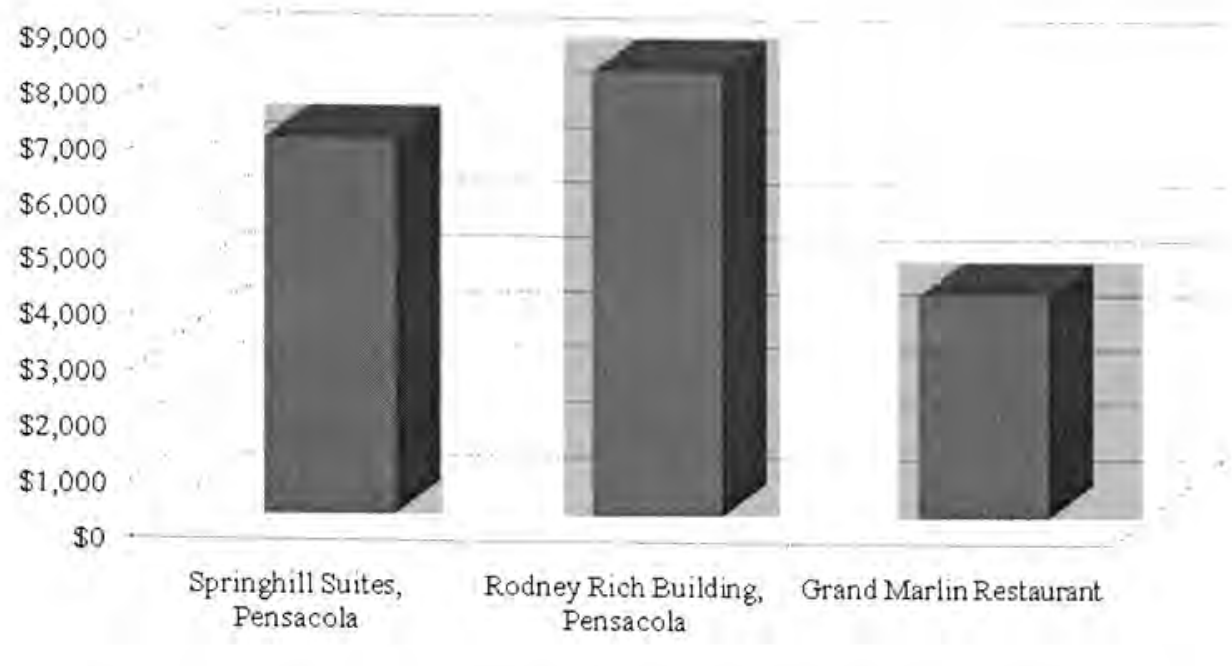

Figure 27 - Cost of vertical closed loop per ton of system capacity

The cost horizontal heat exchangers consists of trenching, polyethylene pipe material and installation cost and backfilling costs. The costs associated with this type of systems are tabulated in Table 11. The depth of the trench can show some variation depending on the type and thermal conductivity of the soil but, generally a 6 to $8 \mathrm{ft}$ trench is used for most applications. Due to the fact that horizontal ground loops require significant amount of free area, horizontal closed loop are rarely used. During the data gathering process, no cost information was gathered for horizontal loop systems. The only cost information available on the literature regarding these applications are reported by Kavanaugh et. al (1995). Updating this study to 2010 costs, per ton cost of horizontal closed loop was calculated as $\$ 4,420$ for residential applications. 
Table 11 - Initial costs for horizontal closed loop systems

\begin{tabular}{|c|c|c|}
\hline $\begin{array}{c}\text { Cost } \\
\text { Component }\end{array}$ & Definition of Cost Items & Unit \\
\hline $\begin{array}{c}\text { Engineering } \\
\text { Design }\end{array}$ & $\begin{array}{c}\text { Modeled as a percentage of total construction cost, } \\
\text { includes civil or mechanical design cost }\end{array}$ & $\$$ \\
\hline $\begin{array}{c}\text { Trenching and } \\
\text { backfilling }\end{array}$ & $\begin{array}{c}\text { Depth of the trench, type of soil determines the type of } \\
\text { equipment used (Main component is augers, rented daily) }\end{array}$ & $\$ /$ day \\
\hline Ground loop & $\begin{array}{c}\text { The polyethylene pipe used for ground loop, depends on } \\
\text { capacity requirements }\end{array}$ & $\$ / \mathrm{ft}$ \\
\hline $\begin{array}{c}\text { Loop Pump } \\
\text { System }\end{array}$ & $\begin{array}{c}\text { The pump used circulation of heat exchange fluid inside } \\
\text { the loop, the capacity of the system determines }\end{array}$ & \$/each \\
\hline $\begin{array}{c}\text { Water Pump } \\
\text { controls and } \\
\text { valves }\end{array}$ & Controls and valves associated with the water pump & \$/each \\
\hline $\begin{array}{c}\text { Pipes and } \\
\text { Fittings }\end{array}$ & Includes all pipes and fitting to and from loop & $\$ / \mathrm{ft}$ \\
\hline Heat Pump & Depends on the capacity required, size and location of \\
the building
\end{tabular}

The cost of open loop heat exchanger consists of the well drilling costs, well caisson, well pump, filter and piping, and grouting costs. The breakdown of initial costs for open loop systems is as defined in Table 12. The depth of the well and sizing of the pipes may depend on the system capacity, the depth of the groundwater and amount of discharge of the groundwater. For these studies, the values obtained from the data gathering trip made to Tampa was used. The average cost calculated using 5 project data for open loop was $\$ 5,982$ per ton capacity for residential applications. 
Table 12 - Initial costs for open loop systems

\begin{tabular}{|c|c|c|}
\hline $\begin{array}{c}\text { Cost } \\
\text { Component }\end{array}$ & Definition of Cost Items & Unit \\
\hline $\begin{array}{c}\text { Engineering } \\
\text { Design }\end{array}$ & $\begin{array}{c}\text { Modeled as a percentage of total construction cost, } \\
\text { includes civil or mechanical design cost }\end{array}$ & $\$$ \\
\hline Drilling & $\begin{array}{c}\text { Depth of the well, type of soil determines the type of } \\
\text { equipment used (Main component is augers, rented daily) }\end{array}$ & $\$ /$ day \\
\hline $\begin{array}{c}\text { Well Casing and } \\
\text { grouting }\end{array}$ & $\begin{array}{c}\text { The casing placed inside the well and grouting in } \\
\text { between, depth and diameter of the well determines }\end{array}$ & $\$ / \mathrm{ft}$ \\
\hline $\begin{array}{c}\text { Well water Pump } \\
\text { System }\end{array}$ & $\begin{array}{c}\text { The pump used for withdrawing and injecting water, the } \\
\text { capacity of the system determines }\end{array}$ & \$/each \\
\hline $\begin{array}{c}\text { Water Pump } \\
\text { controls and } \\
\text { valves }\end{array}$ & Controls and valves associated with the water pump & $\$ /$ ach \\
\hline $\begin{array}{c}\text { Pipes and } \\
\text { Fittings }\end{array}$ & Includes all pipes and fitting to and from wells & $\$ / \mathrm{ft}$ \\
\hline Heat Pump & Depends on the capacity required, size and location of \\
the building
\end{tabular}

\section{Initial Costs of Conventional HVAC systems}

For the conventional system, an air-sourced direct exchange (DX) split system, which is very typical in any residential unit in southern States, was used. This cost item includes all the material, labor, equipment expenses done while installing the system. The initial costs of the conventional system were taken from RS Means Assemblies Cost Data (2010). The assembly for the air source direct exchange split system is as given in Table 13. The values provided in table are per $\mathrm{ft}^{2}$ for a system of 1.83 ton capacity for an apartment corridor of $1000 \mathrm{ft}^{2}$. The book indicates that $450 \mathrm{ft}^{2}$ of apartment corridors is equivalent to $550 \mathrm{ft}^{2}$ for residential living areas. In other words, 1.83 ton capacity of apartment corridors is equivalent to 2.23 ton for dwelling unit is the same cost for a 2045 $\mathrm{ft}^{2}$ of apartment corridor. Based on this, the total cost of the conventional system is calculated as $\$ 3,256$ for a ton capacity. 
Table 13 - Assembly Costs used for Conventional HVAC System

\begin{tabular}{|c|l|c|c|c|c|}
\hline Component & Quantity & Unit & $\begin{array}{c}\text { Material } \\
\text { Cost, \$ }\end{array}$ & $\begin{array}{c}\text { Installation } \\
\text { Cost, \$ }\end{array}$ & $\begin{array}{c}\text { Total Cost, } \\
\$\end{array}$ \\
\hline $\begin{array}{c}\text { Pipe, sub assemblies used } \\
\text { in assembly systems, } \\
\text { refrigerant piping, per ton, } \\
\text { with remote condensing } \\
\text { unit }\end{array}$ & 0.00183 & System & 0.28 & 0.85 & 1.13 \\
\hline $\begin{array}{c}\text { Condensing unit, air } \\
\text { cooled, compressor, } \\
\text { includes standard controls }\end{array}$ & 0.00122 & Ea. & 1.59 & 0.55 & 2.14 \\
\hline $\begin{array}{c}\text { Fan coil A.C., direct } \\
\text { expansion for use with air } \\
\text { cooled condensing unit, } \\
\text { including filters and } \\
\text { controls }\end{array}$ & 0.00037 & Ea. & 0.53 & 0.14 & 0.67 \\
\hline Total & & 2.45 & 2.28 & 3.98 \\
\hline
\end{tabular}

\subsection{2 - Annual Energy Costs}

The annual costs of the considered HVAC systems are the electricity consumptions of the systems. The electricity consumption of the system depends on the heating and cooling loads on the buildings. This shows variation depending upon the type of the building, insulation properties and type of construction.

Out of the eight projects visited, only four of them had annual electricity costs. These projects were all open-loop systems located in Tampa. The annual electricity consumptions of these projects are given in Figure 2. The numbers given in this figure were obtained directly from the utility bills and therefore, include all electricity costs.

Since these numbers does not directly represent the amount of electricity used by the GSHP system and there are not any studies about the electricity consumption of GSHP systems in south Florida, a computer simulation was conducted. The aim of the simulation was to find the electricity consumptions of a typical residential building in 
south Florida and do a projection for the actual electricity consumption of GSHP systems for the projects visited.

For calculating the energy costs of the GSHP system and conventional HVAC system, a house, which was thought to be representative of typical south Florida construction was used as a basis. The house is modeled as a $2500 \mathrm{ft}^{2}$ single story residential unit. The basic three dimensional drawing of the unit is given in Figure 28. The house is modeled for Tampa, FL. The weather data and soil temperatures that are built in the program are used during the simulation.

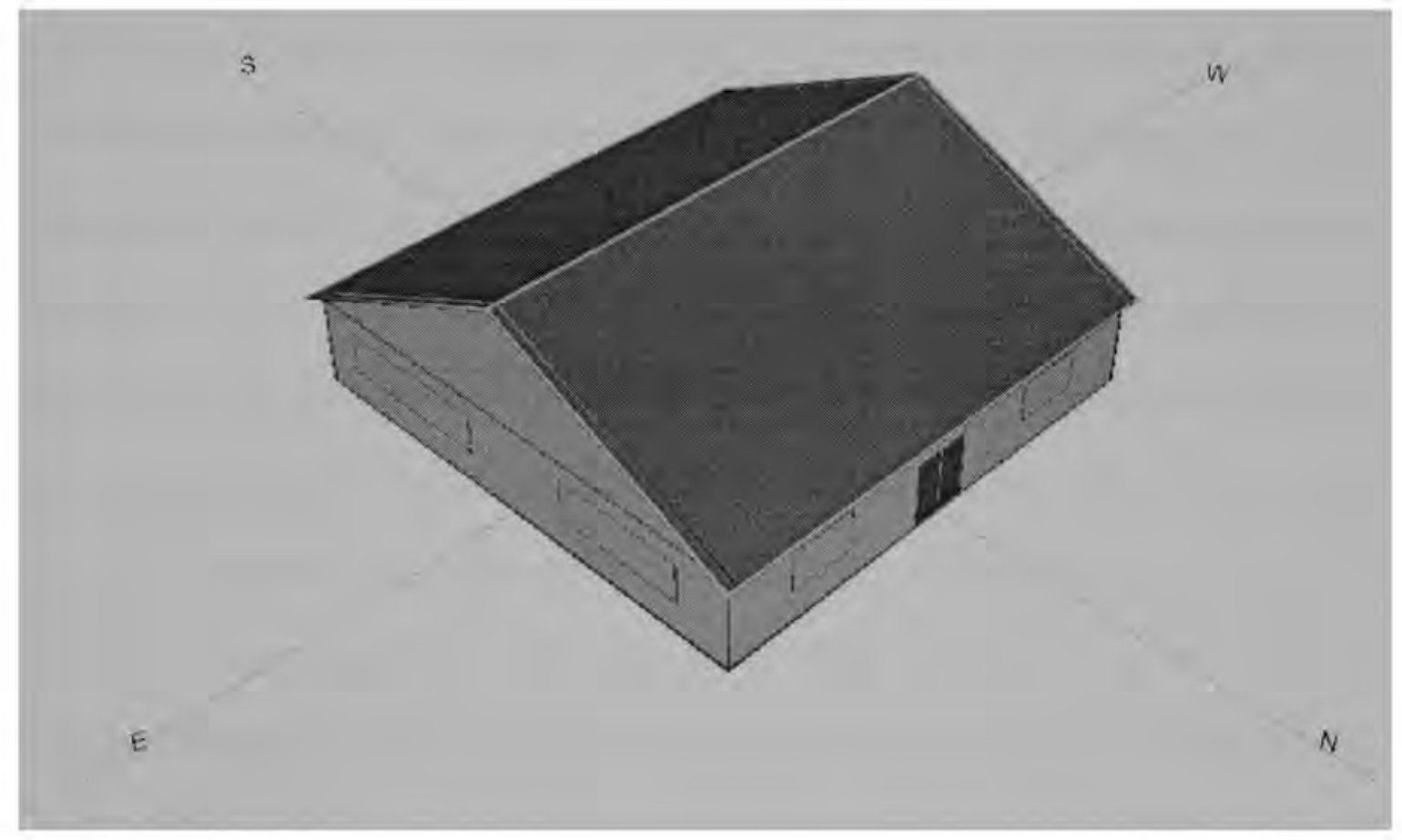

Figure 28 - 3D Geometry of the house used as a basis for analysis

The house is modeled as a $50 \mathrm{ft}$ by $50 \mathrm{ft}$ wood frame structure with a $25^{\circ}$ roof pitch and no attic. The roof does not have any insulation material, the walls has a $1 / 2$ in. 
fiber sheathing and R-19 batt insulation. The foundation is 6 inch thick concrete with R10 insulation, 2 feet deep. The top floor ceiling is insulated with R-30 batt and the finishes are selected as drywall at all interior sections.

2 steel doors at north face and 4 glass doors at south side are used as entering openings. The windows are modeled as $25 \%$ of the wall at all faces except for the north face. $15 \%$ of the wall is modeled as window opening at north face of the structure. No shades, blinds or skylights are used for the simulated house.

The user profile was modeled as a standard family schedule. The holidays and weekends, the building is modeled as occupied. For working hours of working days, the unit stops operating at 8 am and starts running at $4 \mathrm{pm}$. The design temperature for cooling is set as $74^{0} \mathrm{~F}$ for cooling and $73^{\circ} \mathrm{F}$ for heating. The minimum design flow is modeled as $0.50 \mathrm{cfm} / \mathrm{ft}^{2}$. eQUEST energy simulation program has the capability of determining the most appropriate capacity for the type of HVAC alternative selected based on the heating and cooling loads of the building. The monthly loads on the system are shown in Figure 29 for the building simulated. It was seen that the maximum cooling load governs the type of the system size. The simulation showed that a system having a capacity of $48,000 \mathrm{kBtu} / \mathrm{hr}$ (4 tons) will satisfy the requirements. This system size was used while calculating costs for the conventional HVAC system and the GSHP system. 


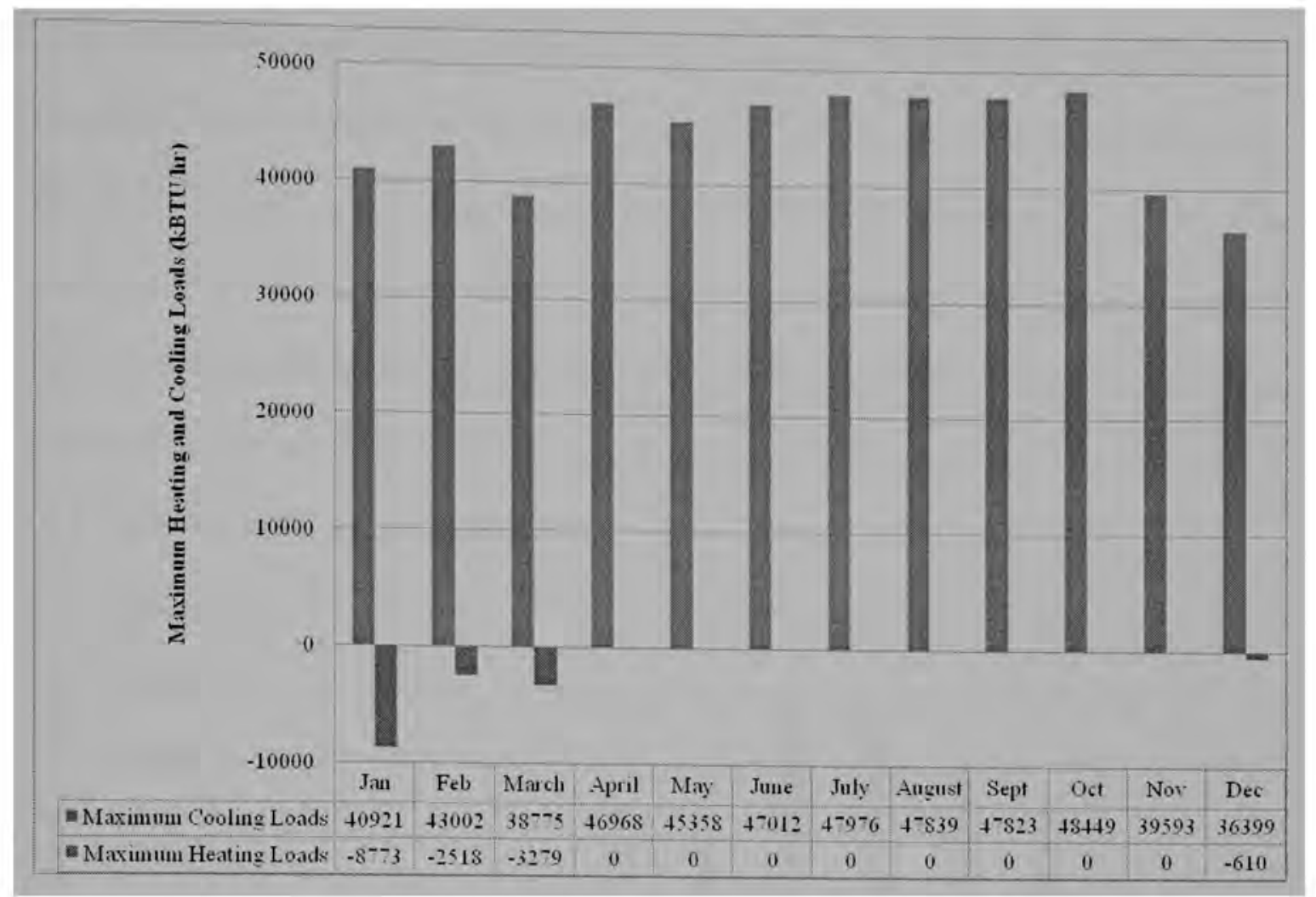

Figure 29 - Monthly heating and cooling loads on the system

For the conventional system, an air-sourced direct exchange (DX) split system, which is very typical in any residential unit in south Florida, was used. The seasonal energy efficiency (SEER) for the conventional unit was set as 10 and coefficient of performance (COP) was set as 2.8 for heating.

For the GSHP system, a vertical closed loop system, which is the most typical type, was used. This system is commonly used as it does not require much space for heat exchanger as other GSHP system does and is not as dependent on geographical conditions of the location. The energy efficiency (EER) for the GSHP unit was set as 19 and coefficient of performance (COP) was set as 4.0 for heating. 
The kWh consumption of both systems has been calculated using eQUEST. The simulated monthly electricity consumptions for both systems are presented in Figure 30.. The base electricity price for this study was taken as $0.107 \$ / \mathrm{kWh}$. Later on, possible fluctuations in the electricity price and its effects are considered. Based on this utility rate, the annual energy for the two systems is calculated and the results are given in a graphical format at Figure 31. It can be seen that the GSHP system provides a net saving of $\$ 739$ annually for a 4 ton system.

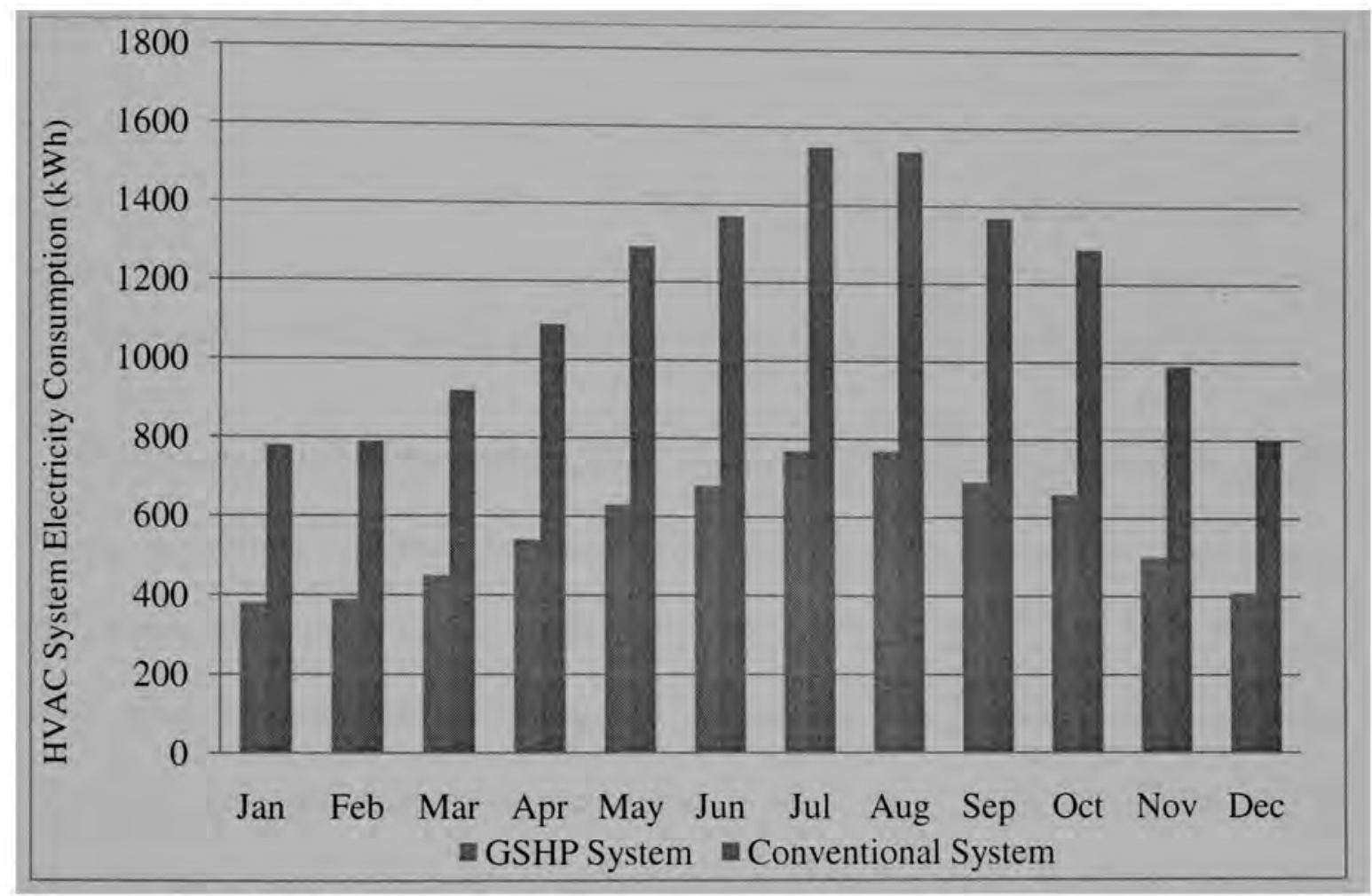

Figure 30 - Monthly electricity consumptions of the two systems considered in simulation 


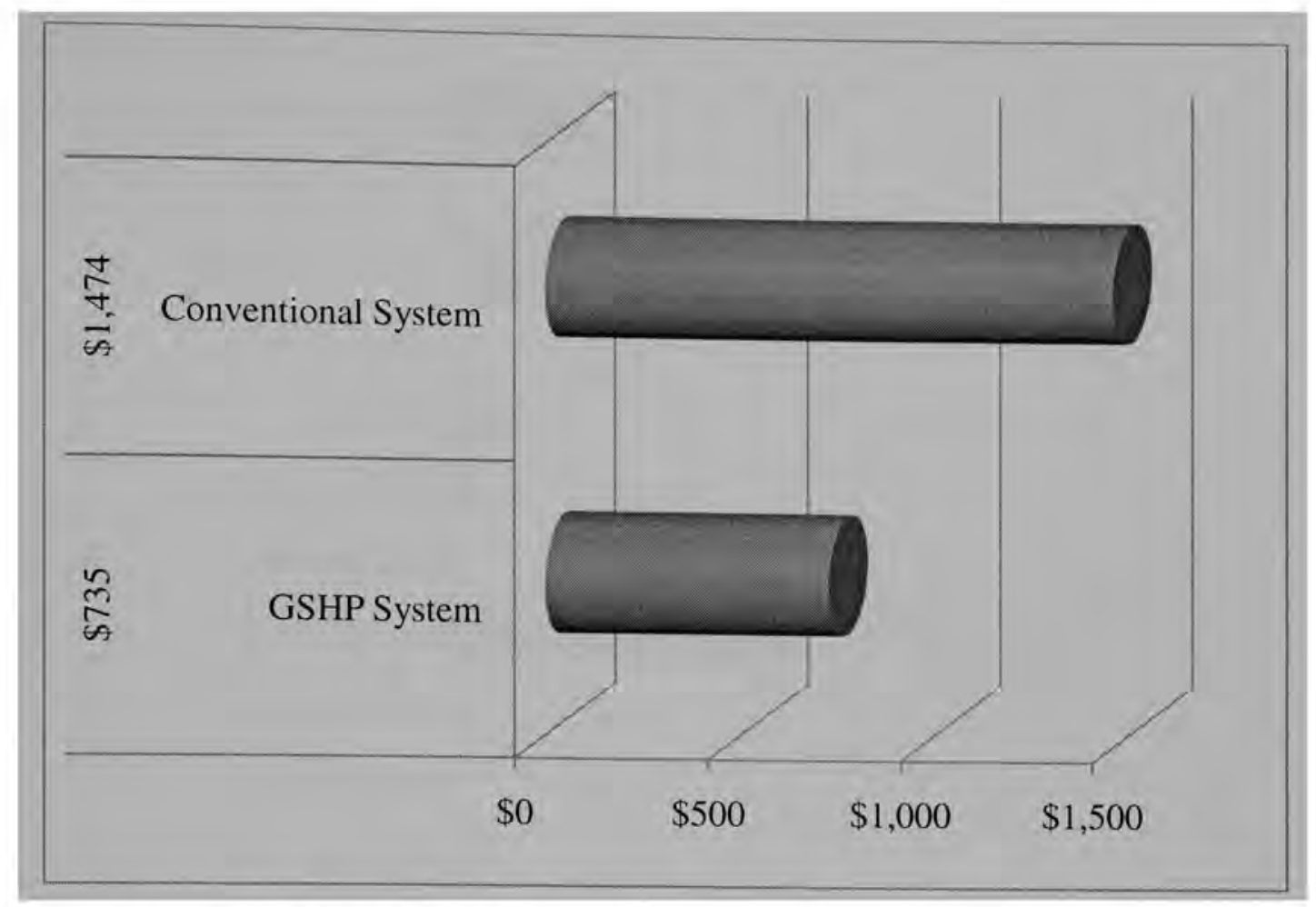

Figure 31 - Annual electricity costs for the two systems considered in simulation

The total electricity consumptions for the conventional system and the GSHP system are shown in Figure 32 along with other electricity usages. The total annual electricity consumption for the house was calculated as $27,391 \mathrm{kWh} .13,778 \mathrm{kWh}$, or $50 \%$ of this consumption was due to the conventional HVAC system. For the GSHP system, the total annual electricity consumption was calculated as $20,841 \mathrm{kWh}$, and 6,862 $\mathrm{kWh}(33 \%)$ of this consumption was due to the GSHP system. Assuming that these percentages also apply to the collected actual data, the total and electricity consumption costs are calculated for the projects are as shown in Figure 33. 


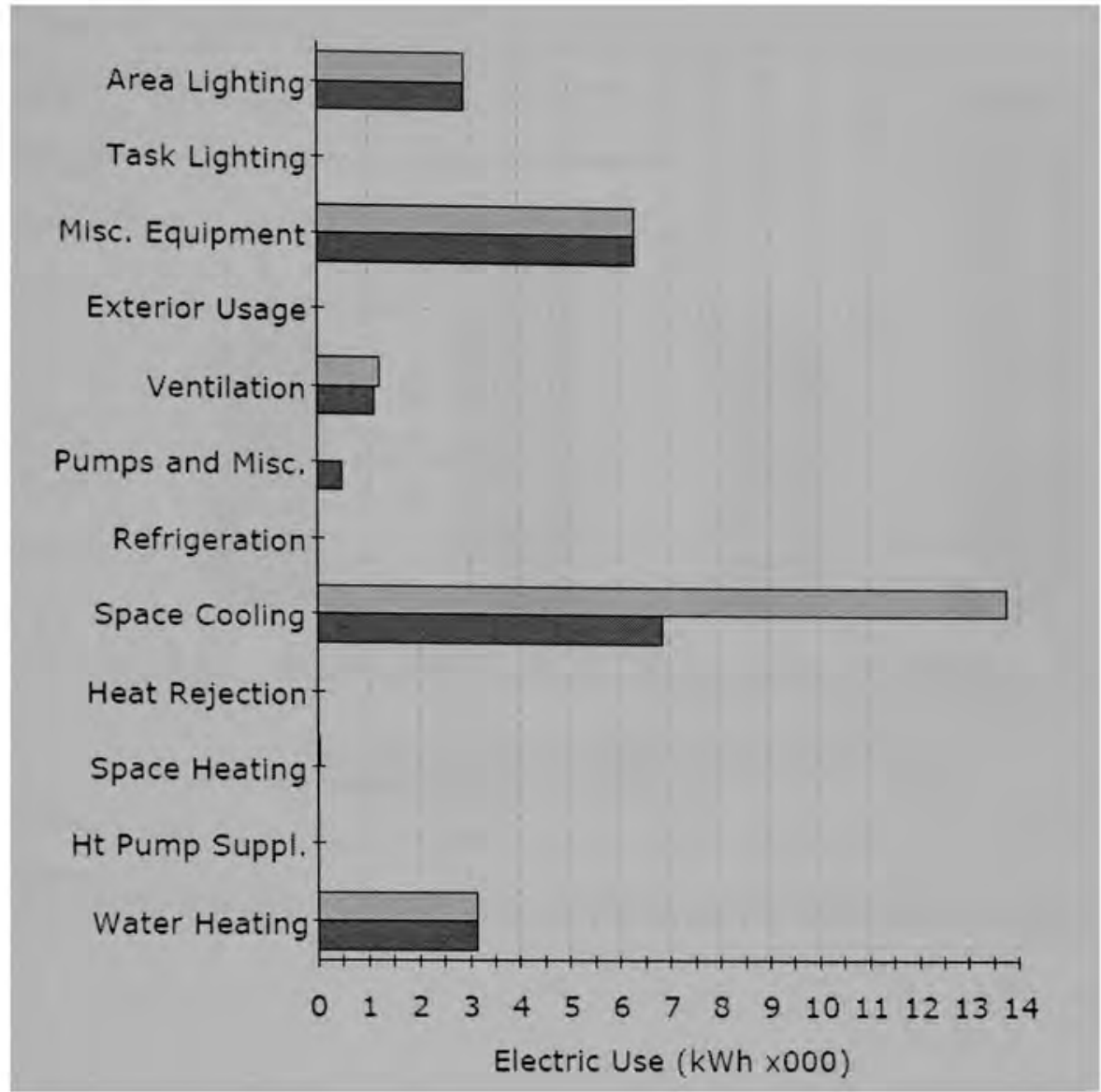

Figure 32 - Electricity consumptions for two systems considered

In a similar fashion, the electricity consumptions for these projects if they were run on conventional HVAC systems are shown in Figure 34. These figures were calculated based on the percentages found by the simulation run. 


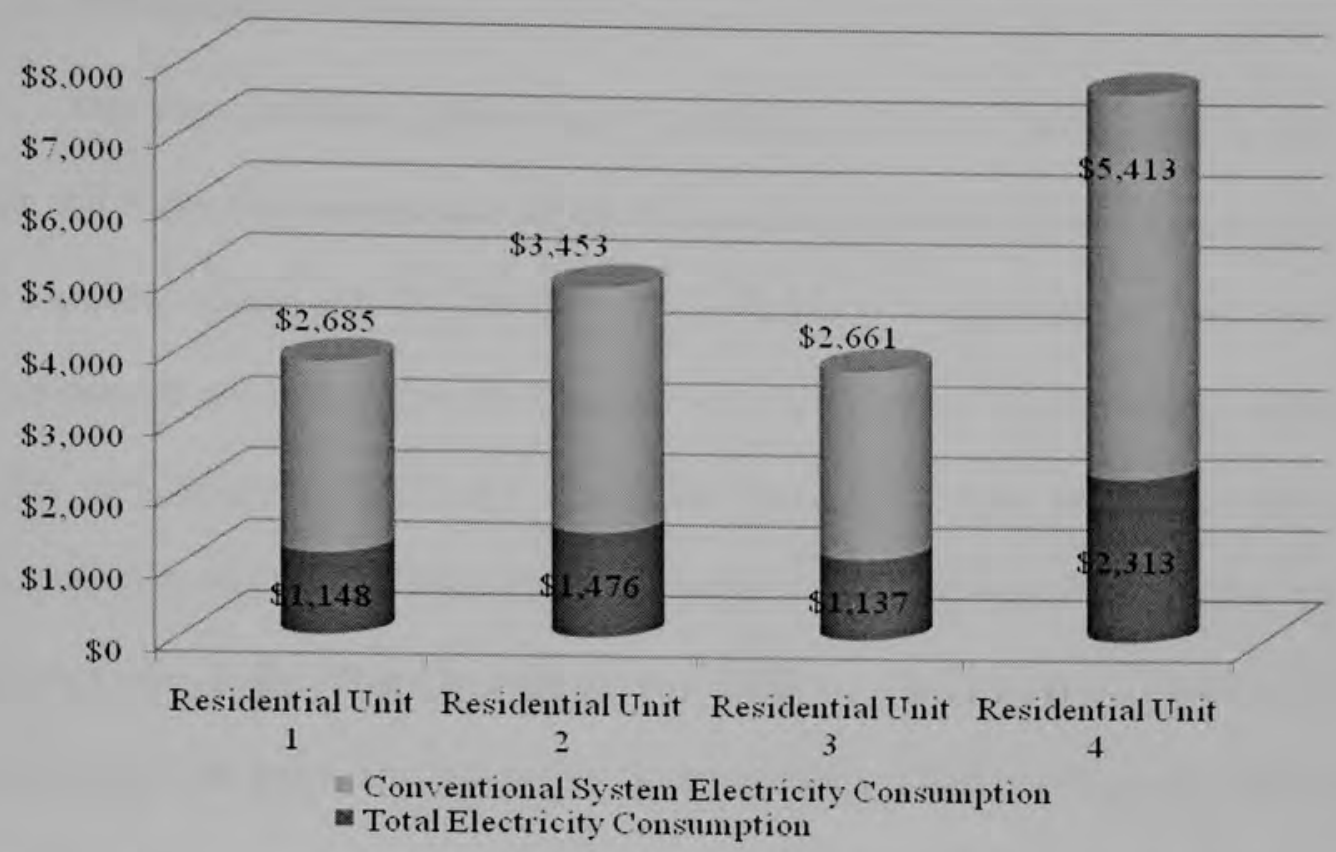

Figure 33 - Total electricity consumption for units with GSHP and conventional systems

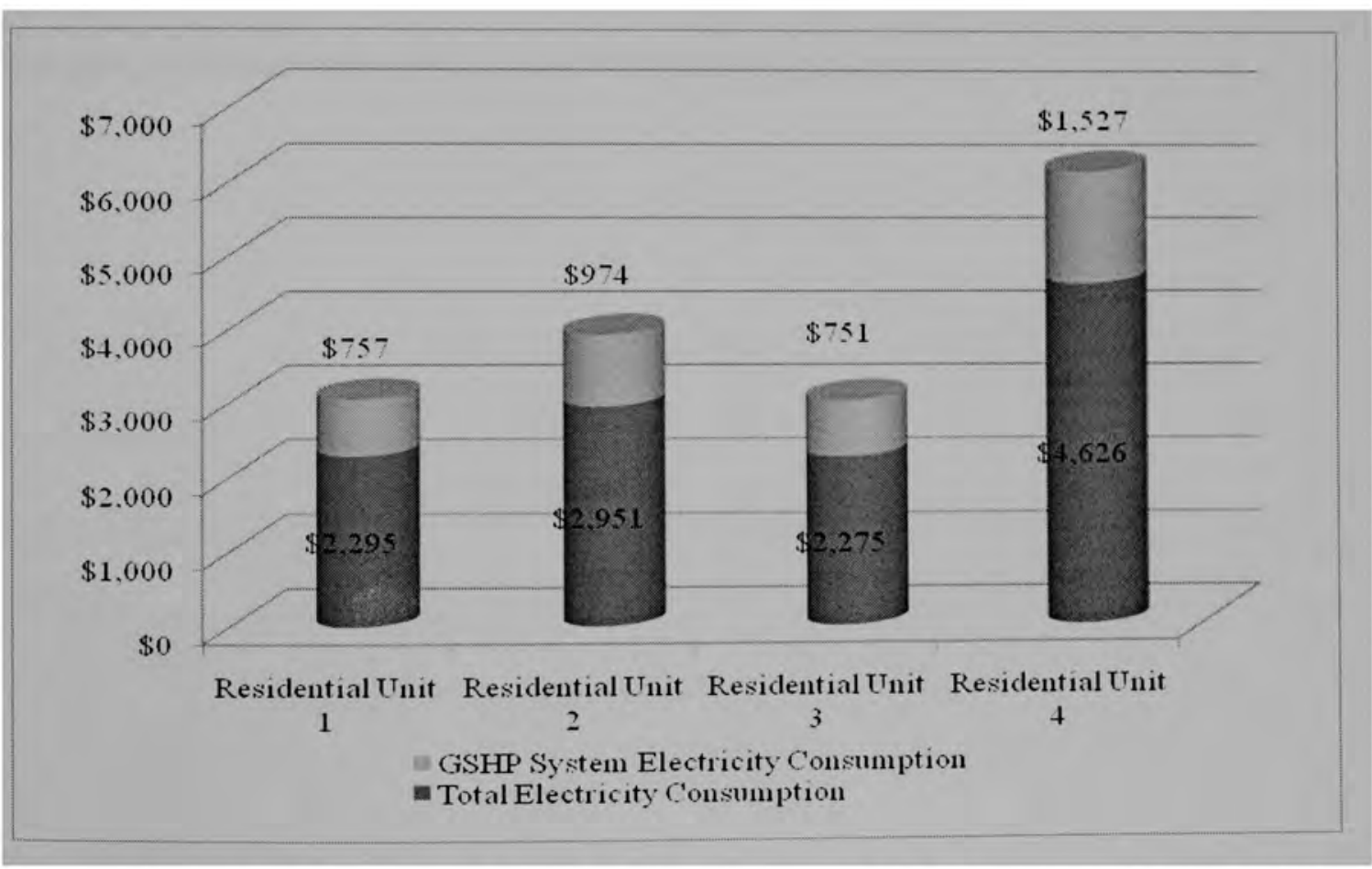

Figure 34 - Electricity costs of GSHP and conventional HVAC systems for residential units 


\subsection{3 - Maintenance Costs}

This item includes expected and unexpected costs that are associated with the repair and corrective maintenance of HVAC systems. In terms of maintenance cost, the only available source was the literature. The contractors or the manufacturers were not able to provide any information for this cost item. Still, there is several number of studies on this area as given in Chapter 2 and the findings of these studies are relatively consistent (see Figure 35). Therefore, the maintenance costs provided in these models have been used in the life-cycle study for the GSHP system. The costs provided for both systems were unit prices for square foot of the building, which are then converted to per ton. These prices were used and the annual maintenance costs were calculated as $\$ 3.76 /$ year for the GSHP system tonnage. The maintenance costs of GSHP systems are not periodic or regularly occurring. These costs are usually associated with possible leakages, problems with valves, motor or thermostat problems. 


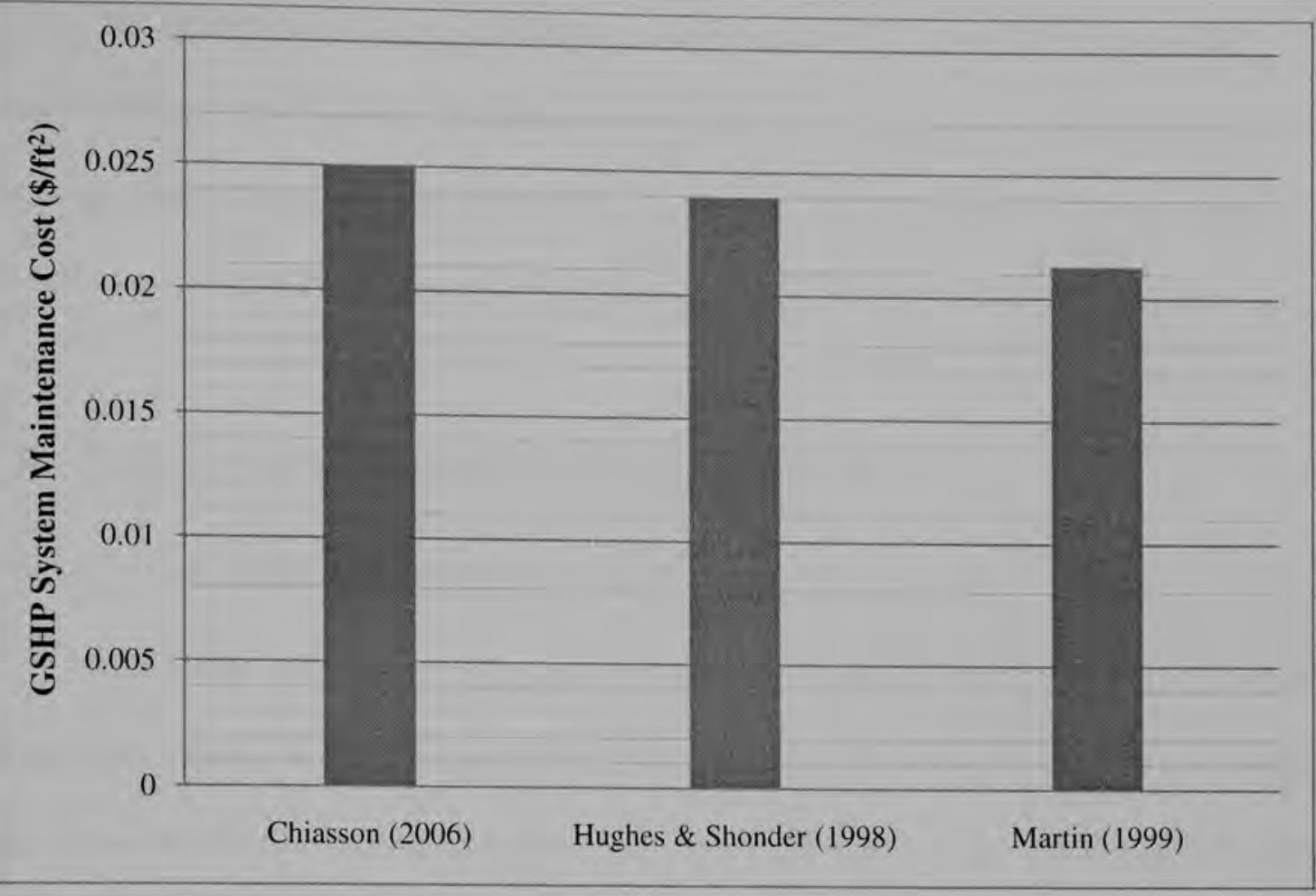

Figure 35 - Maintenance costs for GSHP systems

For maintenance cost of conventional systems, RS Means Facility Maintenance Cost Data was used. $\$ 0.102 / \mathrm{ft}^{2}$ cost for conventional HVAC system was computed to per ton as $\$ 63.75 /$ ton.

\subsection{4 - Periodic Costs}

This includes the expected parts change in HVAC systems. Certain parts of these systems will be replaced at specific intervals. The GSHP system does not require any periodic replacements during the life time used. For this study the life-time was taken as 20 years. At the end of 20 years, heat pump has to be replaced for open loop and closed loop systems. 
According to the RS Means Facility Maintenance Cost Data, the conventional system requires some parts to be replaced at the end of 10 year usage. This items are listed as compressor, condenser fan bearing, condenser fan motor and refrigerant. The cost of these items was estimated as $\$ 3,991$ for a 5 ton systems or $\$ 868$ per tonnage.

\section{4 - Life Cycle Cost and Sensitivity Analysis}

\subsection{1 - Life Cycle Cost Analysis}

Life-cycle cost study has been conducted based on the collected data and projections stated in the previous part. Net present worth of the projects has been calculated with base costs obtained and they are compared with the conventional system costs. The payback period of each project is calculated. Later on, the cost items have been changed within the possible ranges and the effect of these changes on the life cycle costs and payback periods are presented.

The cost items that have been used in life-cycle cost study are listed in Table 14. Initially, life cycle costs for the imaginary simulated house were calculated per ton. The breakeven analysis for the two systems is as shown in Figure 36. The analysis showed that then breakeven point for the GSHP system was 1 years. In other words, the GSHP system starts making profit for the owner after the end of the $1^{\text {st }}$ year for a new construction. 
Table 14 - Life Cycle Costs and Items Considered for two systems for one ton capacity

\begin{tabular}{|c|c|c|}
\hline & GSHP System & Conventional System \\
\hline Capital Costs, $\$$ & 3,334 & 3256 \\
\hline Annual Electricity Costs, $\$$ & 189.25 & 287 \\
\hline Maintenance Costs, $\$$ & 3.76 & 23.38 \\
\hline Periodic Costs, $\$$ & - & $868(10$ Years) \\
\hline Life-cycle & 20 & 20 \\
\hline Life-cycle cost & $\mathbf{\$ 6 , 2 0 6}$ & $\mathbf{\$ 8 , 5 2 0}$ \\
\hline
\end{tabular}

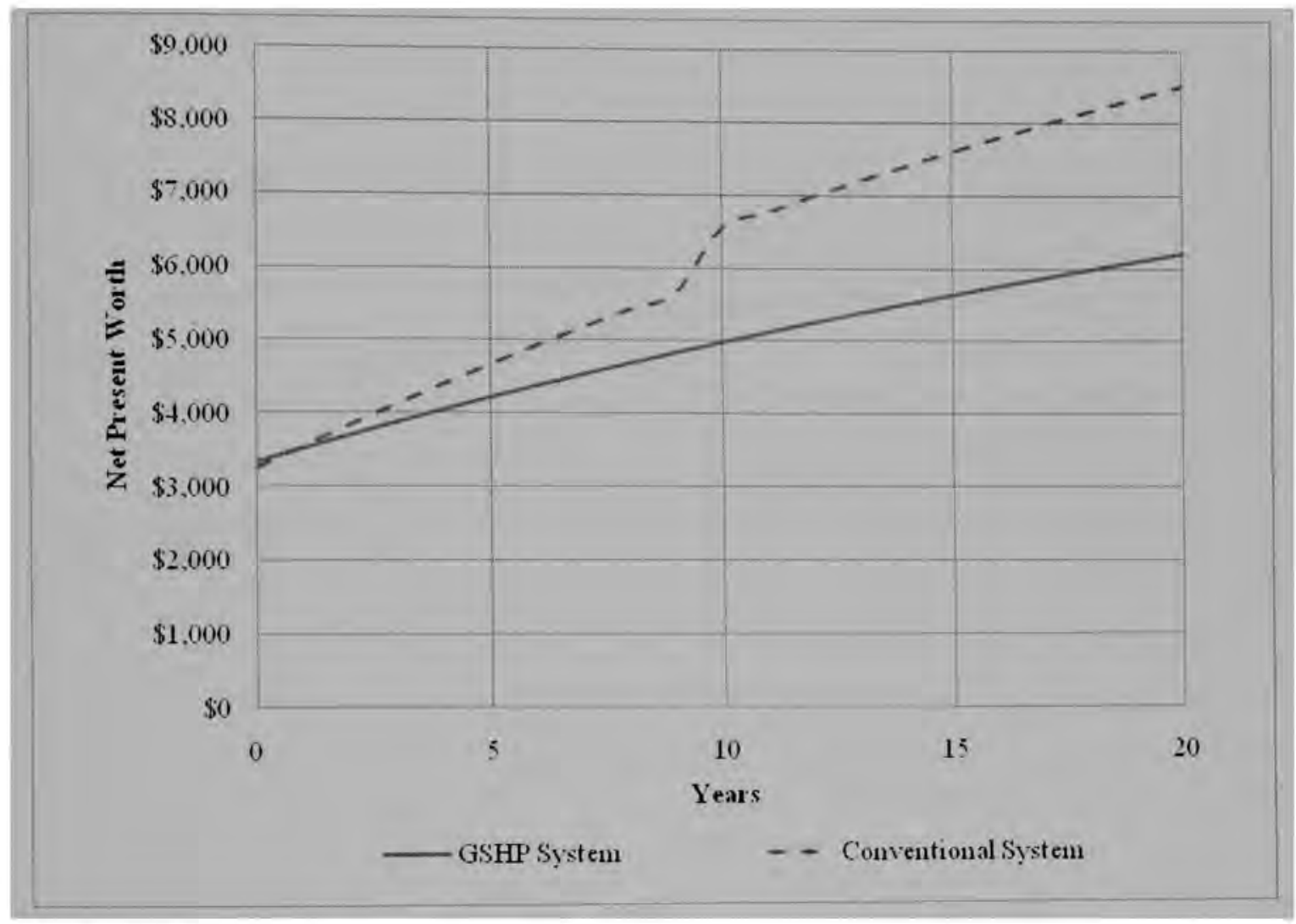

Figure 36 - Life-cycle cost calculations of the two alternatives per ton of capacity

In, a similar fashion, comparative life-cycle costs for residential units 1 to 4 are calculated and are given in Figure 37 to Figure 40. In residential unit 1 and 2, open loop GSHP systems were not installed on new construction but were installed by removing the existing conventional HVAC system. Therefore initial costs for that particular building was taken as zero. For residential unit 2, the wells that the owner drilled were used and 
hence one of the major expenses was zero. However, it was seen that the GSHP system does not pay back in the economical life time. Residential units 3 and 4 were new construction, so initial values of the calculated conventional system were used. For residential unit 1 , the breakeven point was calculated as 17 years, for residential unit 2 , the breakeven point was 20 years and it was 1 year for unit 3 . In residential unit 4 , GSHP system seemed to be unfeasible.

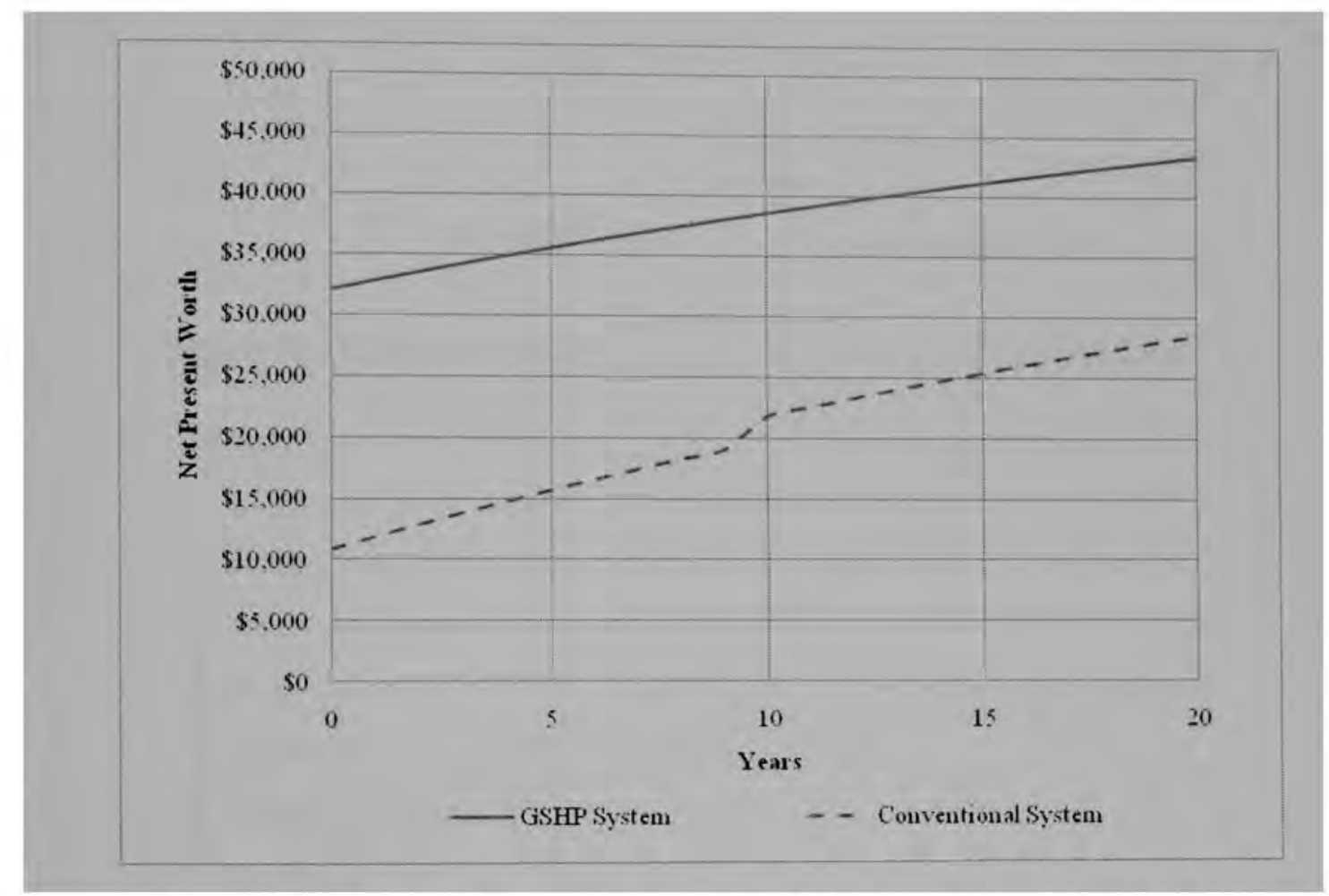

Figure 37 - Comparative life-cycle cost calculations for residential unit 1 


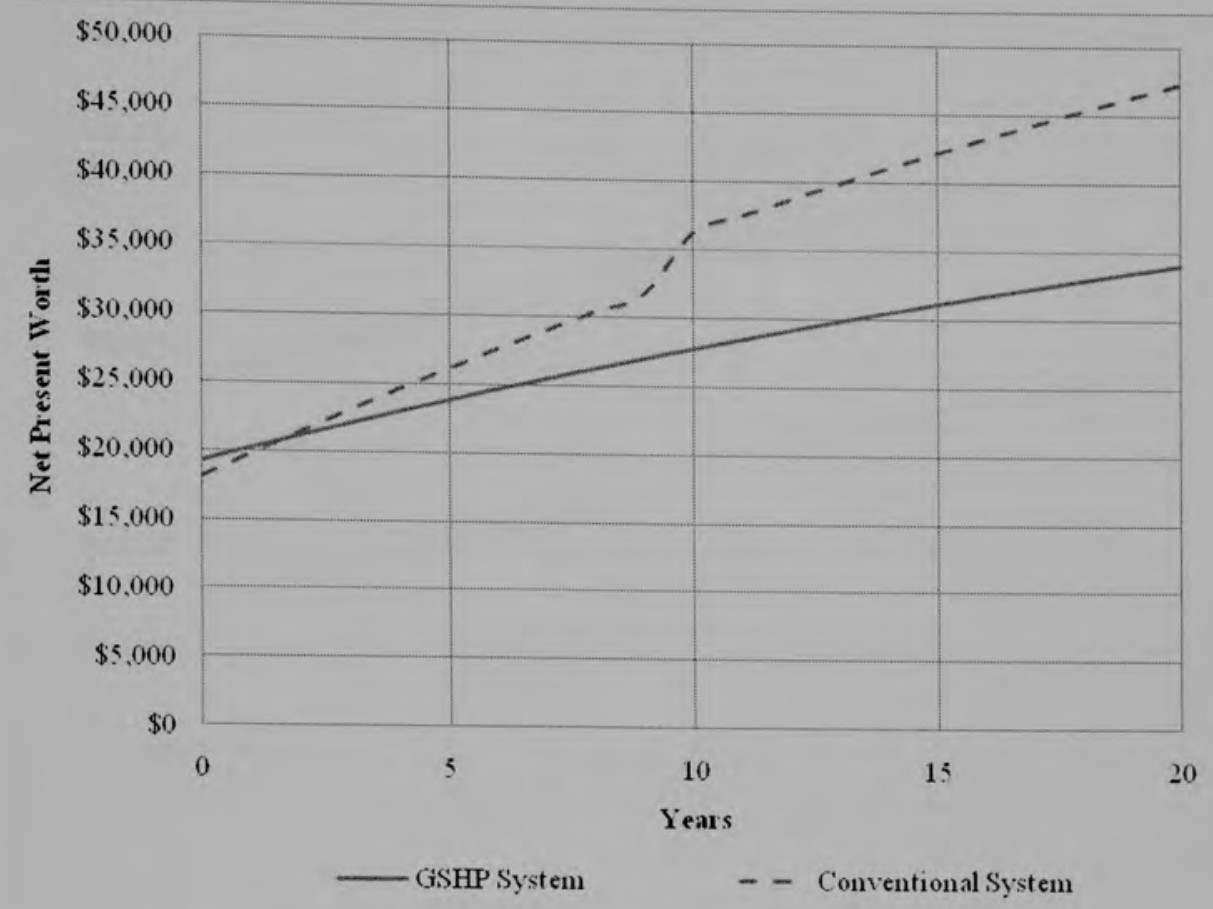

Figure 38 - Comparative life-cycle cost calculations for residential unit 2

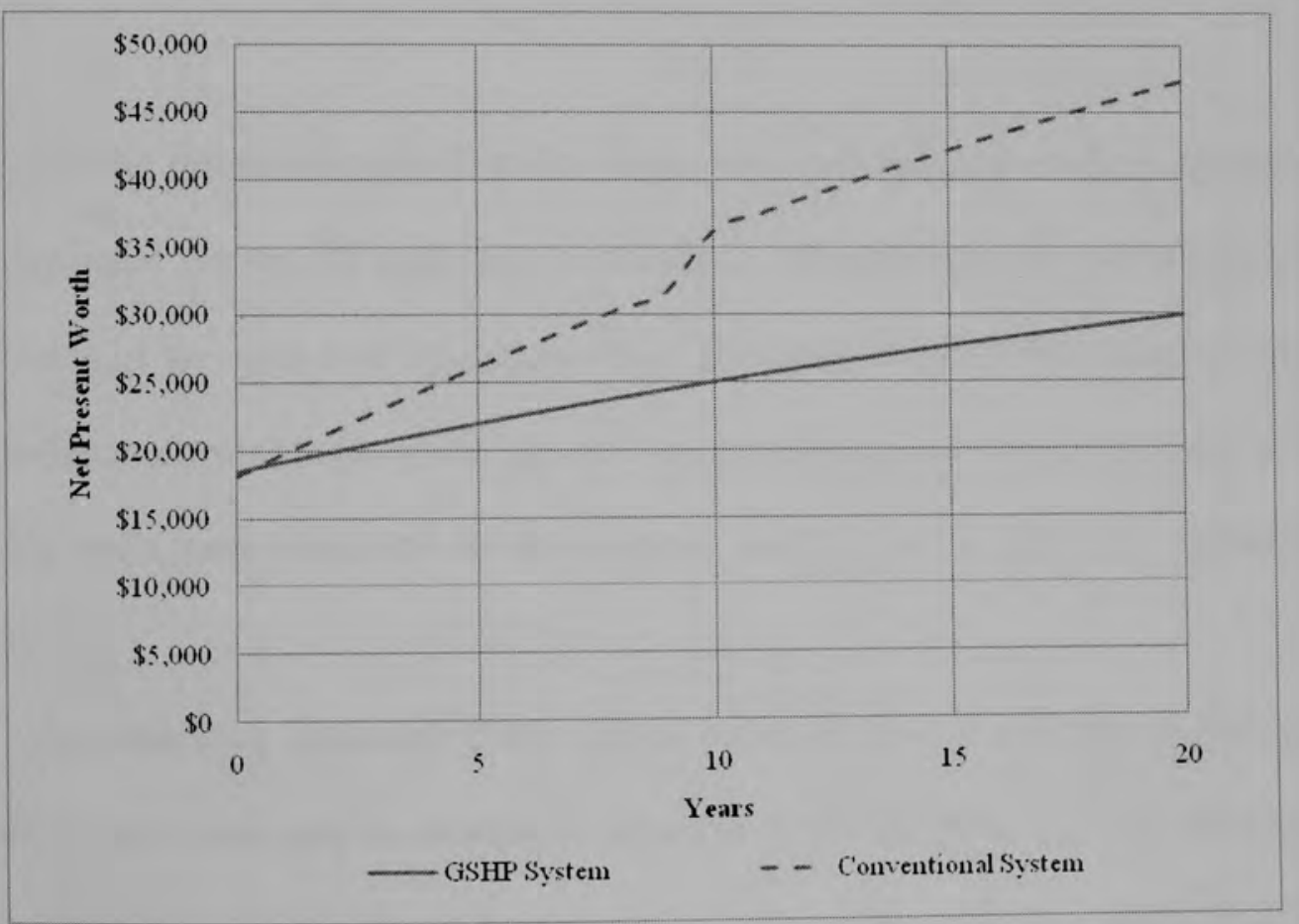

Figure 39 - Comparative life-cycle cost calculations for residential unit 3 


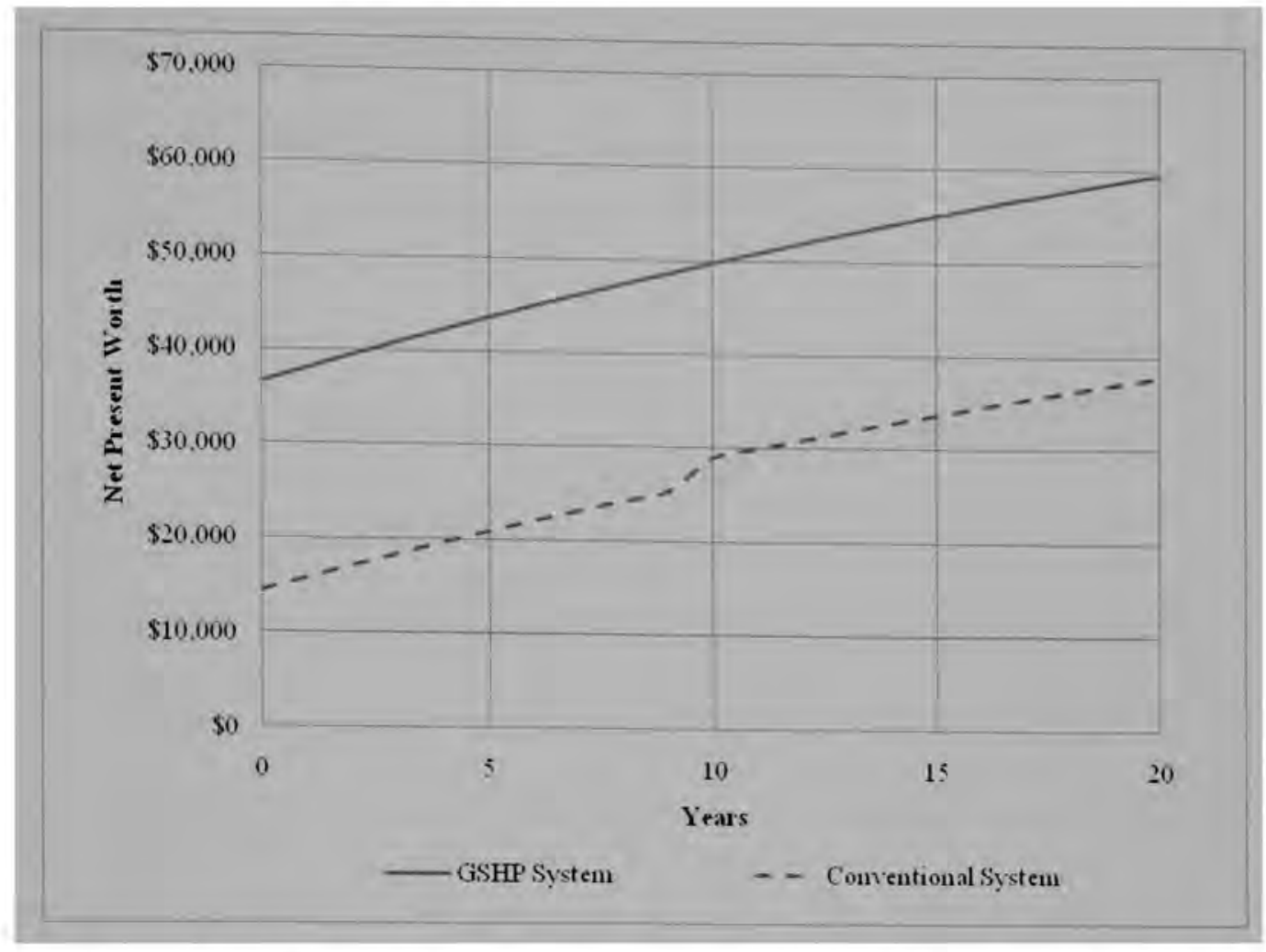

Figure 40 - Comparative life-cycle cost calculations for residential unit 4

For the residential units 1 and 4 , it was observed that conventional system was more favorable for the 20 year period considered. This fact can be attributed to high initial costs of the open loop system installed. The reasons behind this high cost can be poor design, unfavorable ground or groundwater conditions. For residential unit 2 already available wells were used, and the initial costs were as low as that of a conventional system.

An interesting observation that should be made here is that almost two of the residential units were able to prove cost effective in the life time of the system among open loop systems. From closed loop systems, comparative life-cycle costs of Rodney Rich Building were calculated. In this calculation all the costs except the initial costs of 
the building was taken from the model developed. From Figure 41, it can be seen that for this building, the payback period was 10 years.

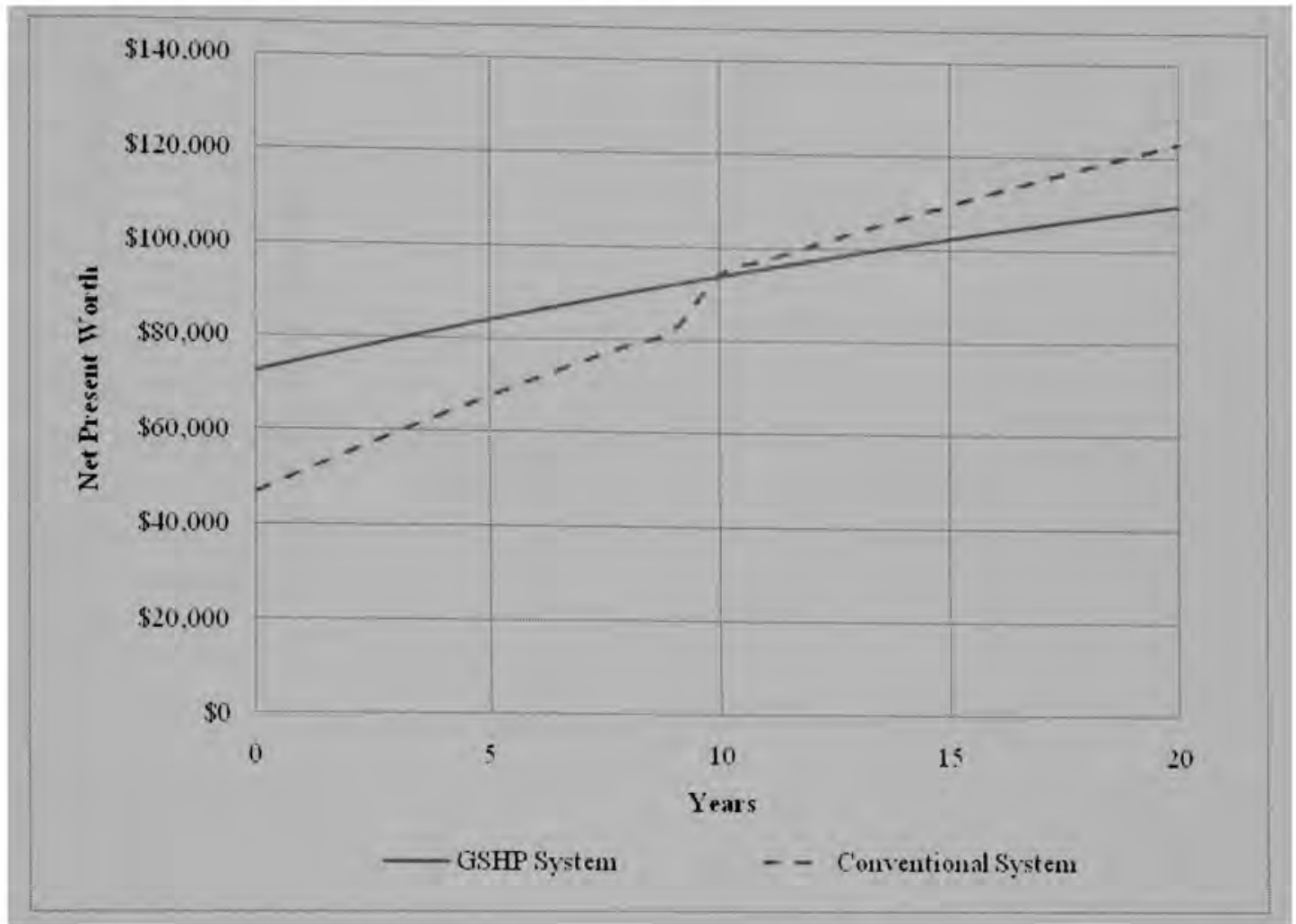

Figure 41 - Comparative life-cycle cost calculations for Rodney Rich Building

From Figures 42 to 47 , cash flow diagrams are given in the same order life-cycle cost graphs are presented. In the cash flow diagrams, perspective of an investor who installed a GSHP system is taken as the basis. In this regard, the savings obtained from electricity are presented as positive, whereas the difference between the higher initial cost of the GSHP system and conventional system is presented as negative. 


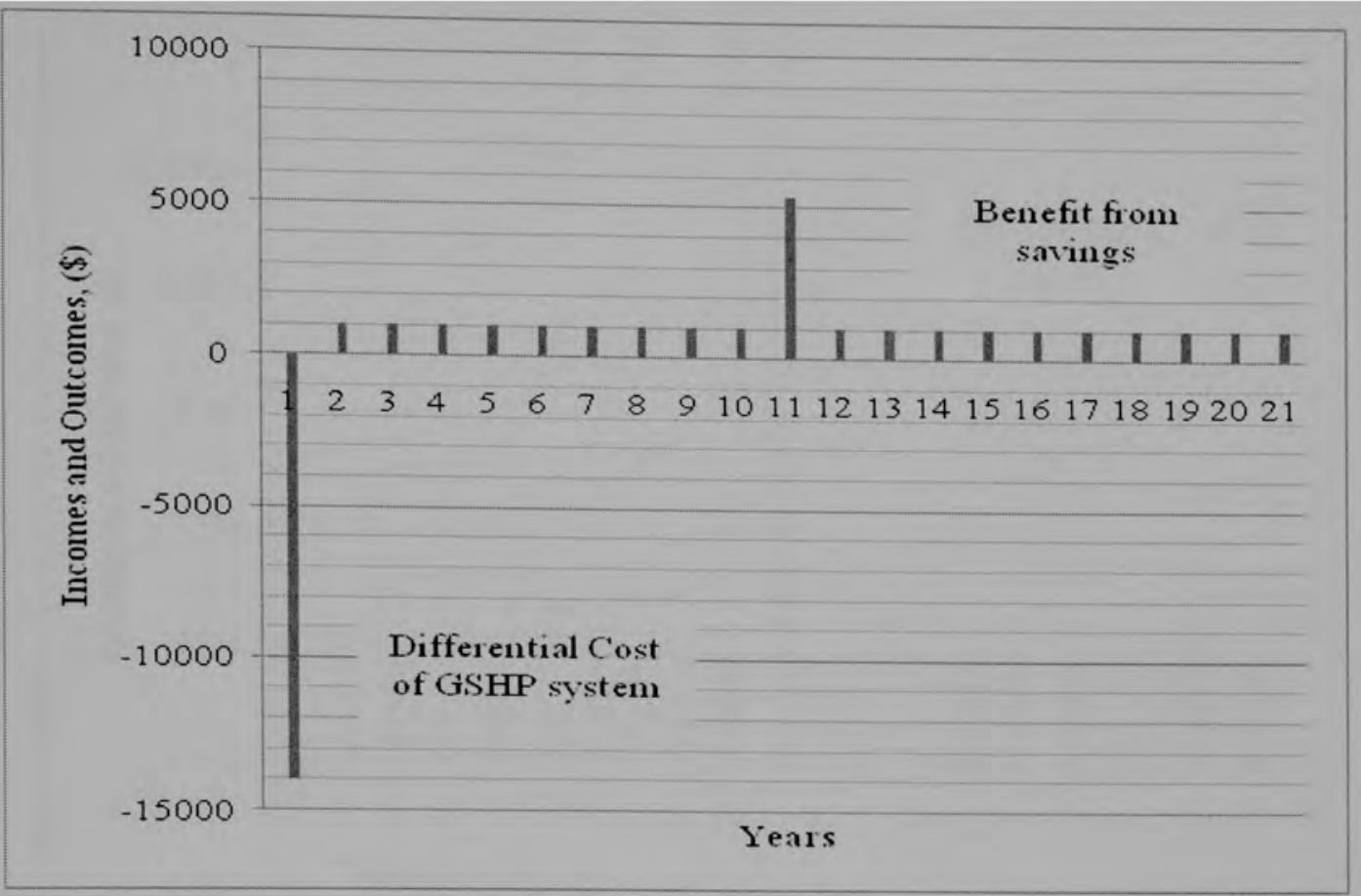

Figure 42 - Cash flow diagram for residential unit 1

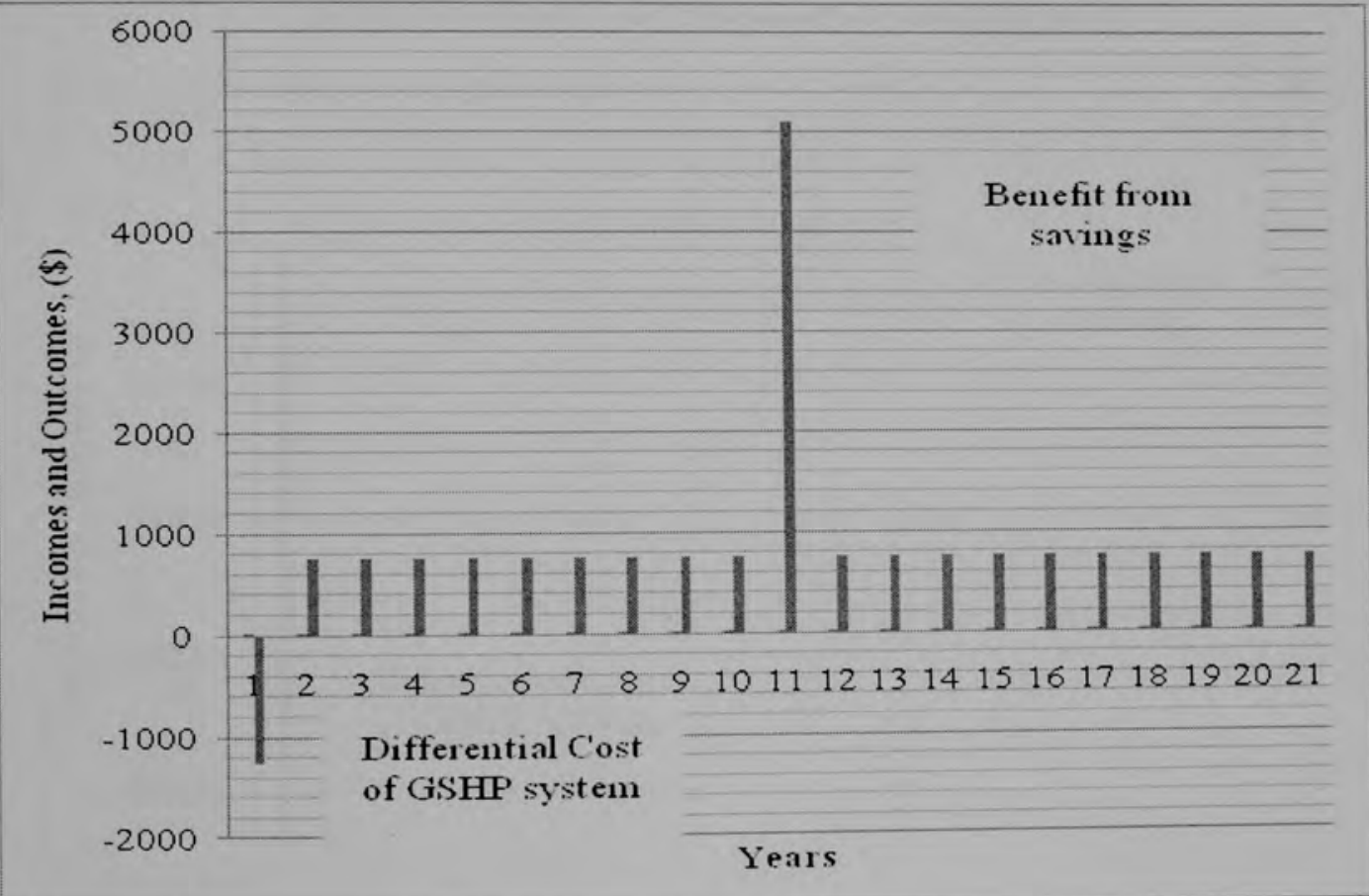

Figure 43 - Cash flow diagram for residential unit 2 


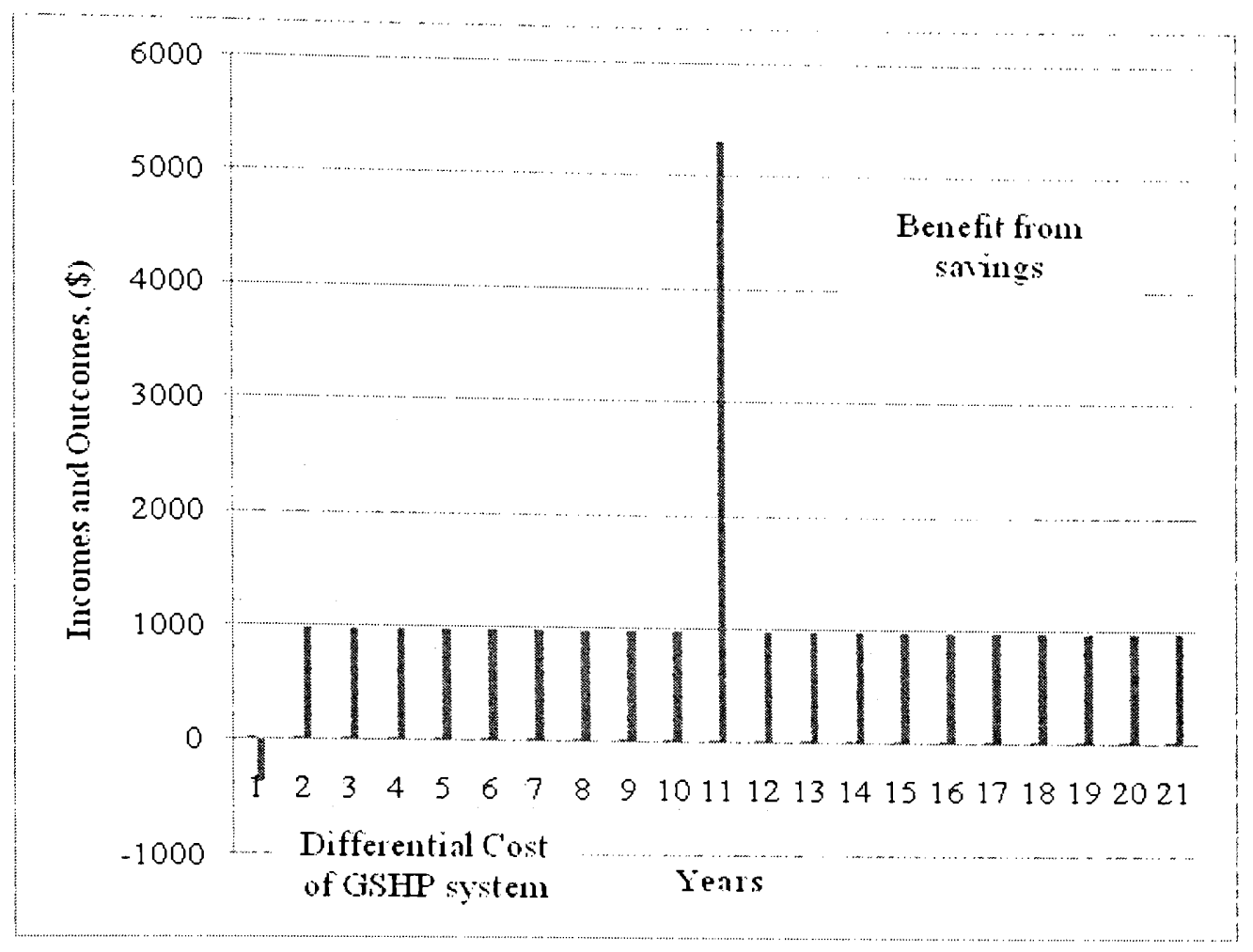

Figure 44 - Cash flow diagram for residential unit 3

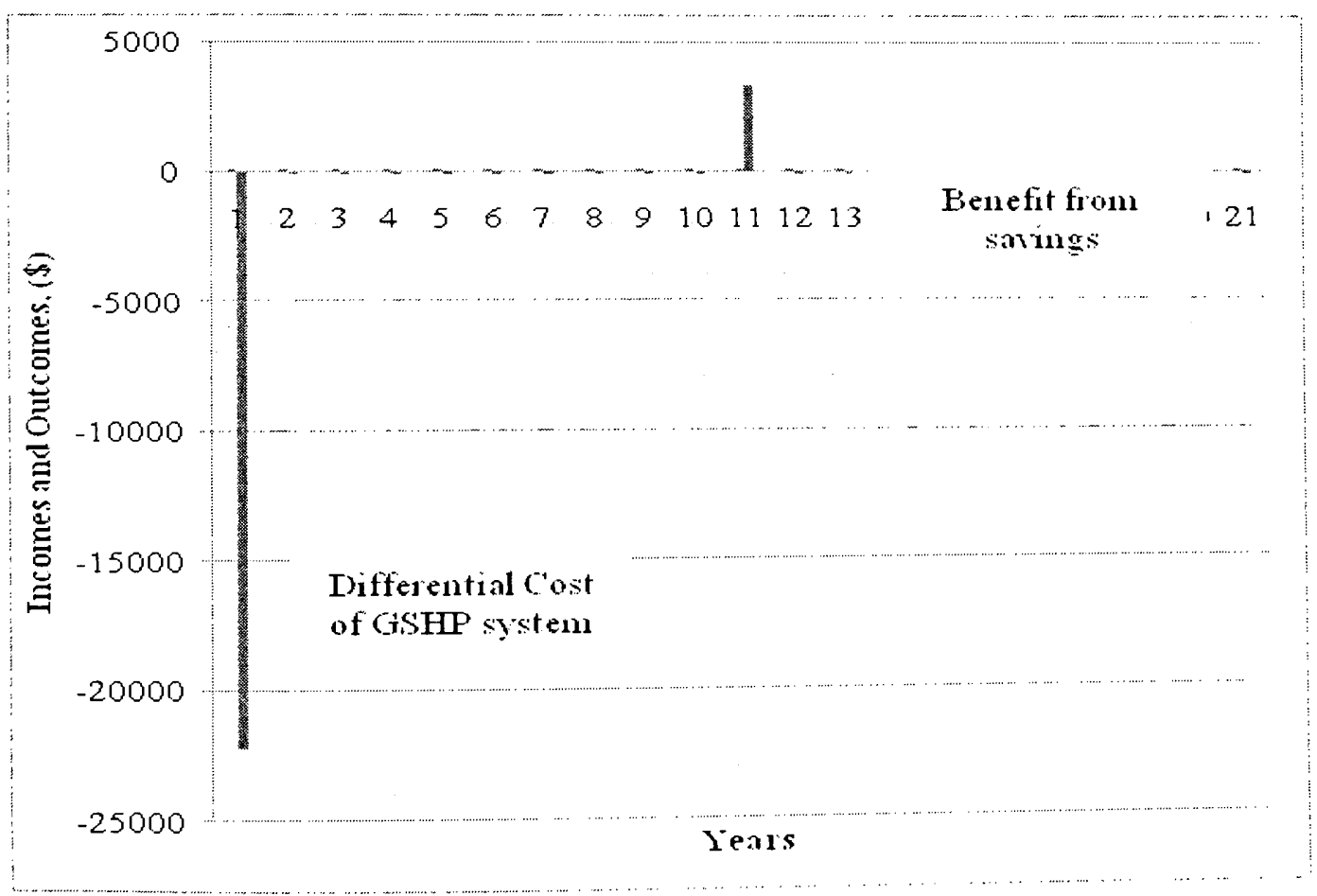

Figure 45 - Cash flow diagram for residential unit 4 


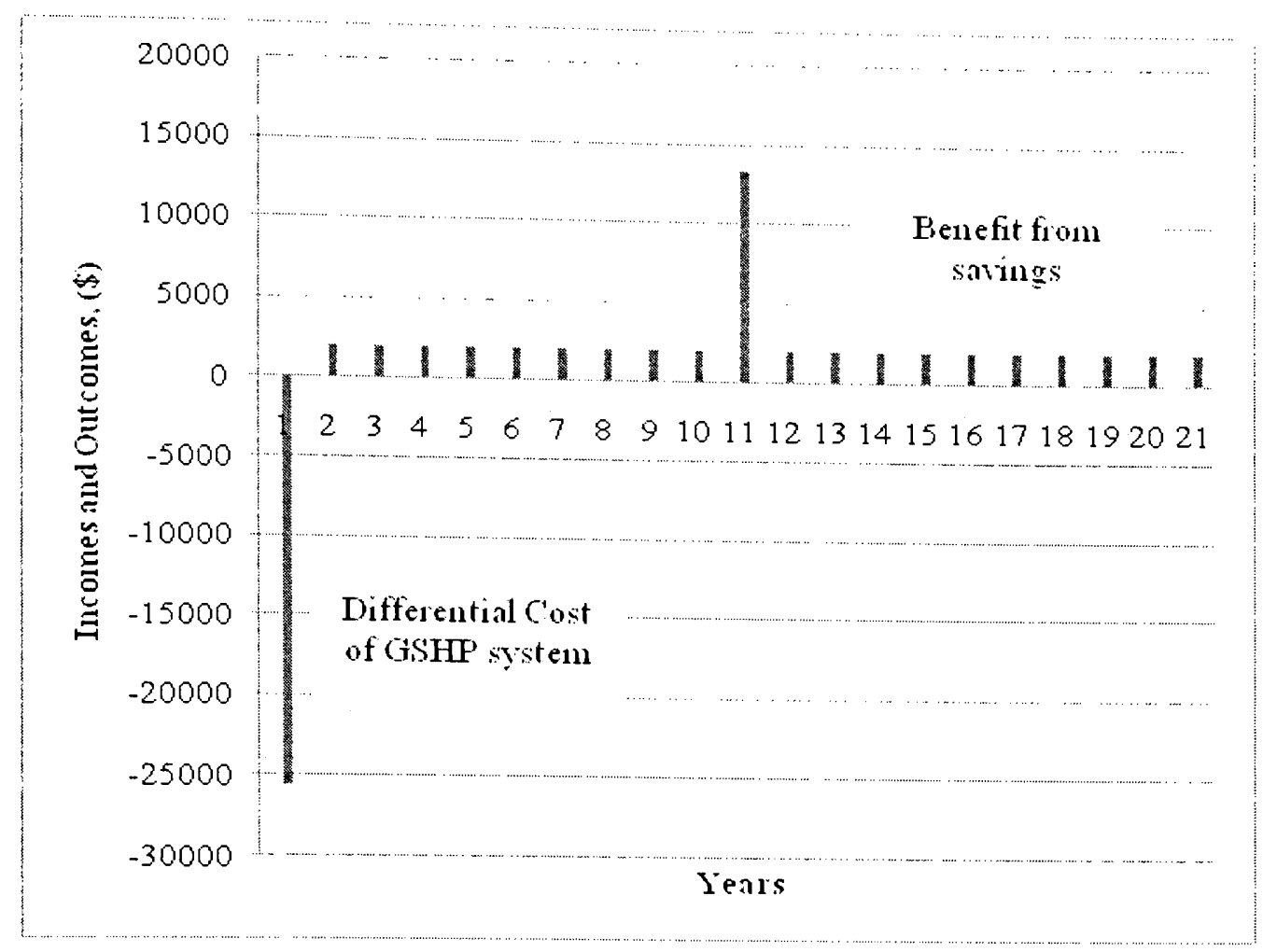

Figure 46 - Cash flow diagram for Rodney Rich Building

Based on these calculations, it can be seen that the GSHP systems are not economically favorable for replacement of an functioning conventional system. However, depending on the usage and building specifications, GSHP systems can yield favorable results as the electricity consumption of them will almost always be lower than conventional systems.

In these calculations, the current incentive programs were not considered. Currently, there are several incentive programs that are available to residential and commercial GSHP applications. The main incentive offered by government is a $\% 30$ tax rebate program without any caps. Also, in some parts southern States, a \$300/ton rebate is offered by energy companies. When these rebates are considered, many of the projects 
considered above have attractive payback periods. The life-cycle costs for the same projects when the incentives are applied are as shown from Figure 47 to 51.

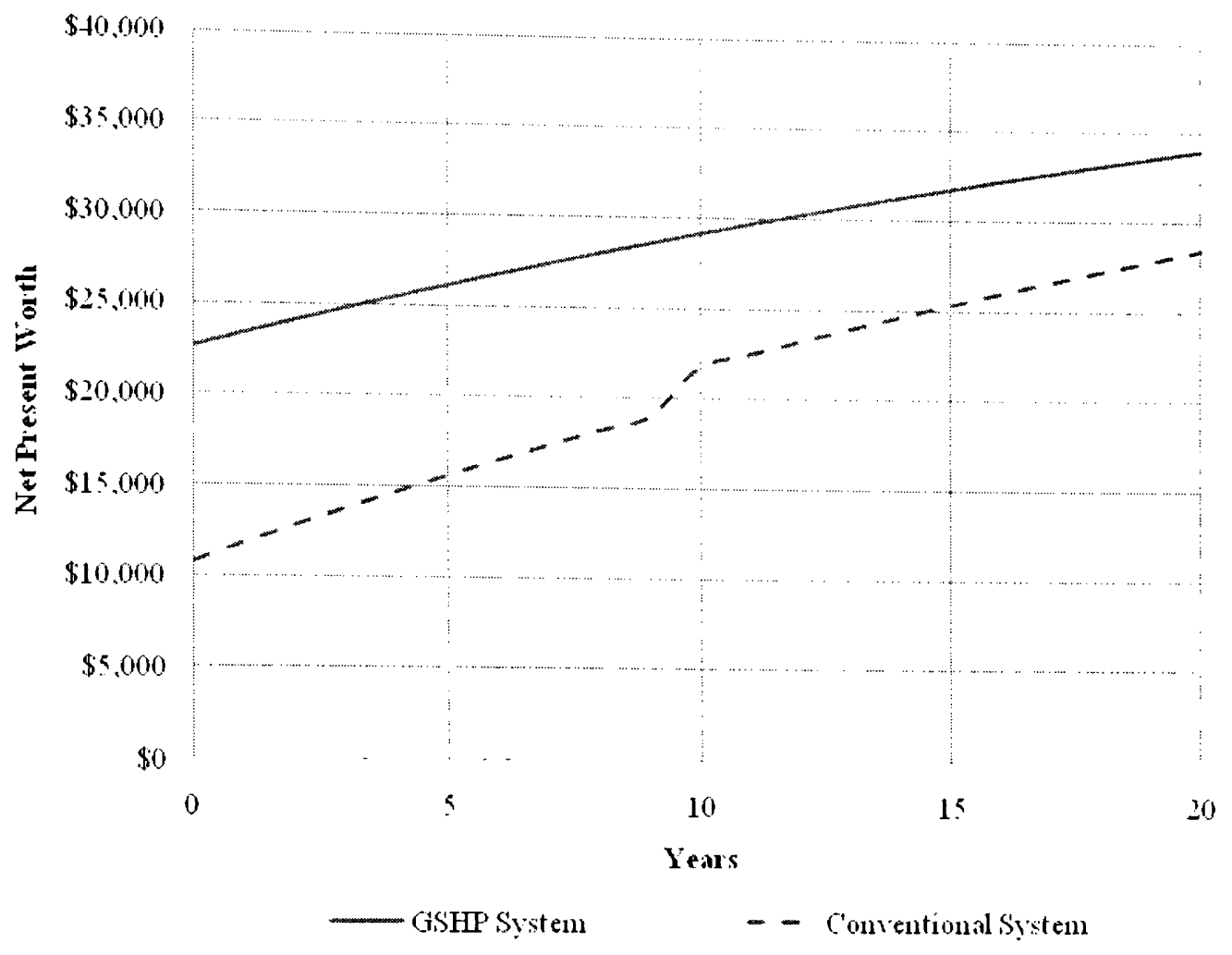

Figure 47 - Life-cycle cost calculations for residential unit 1 after incentives 


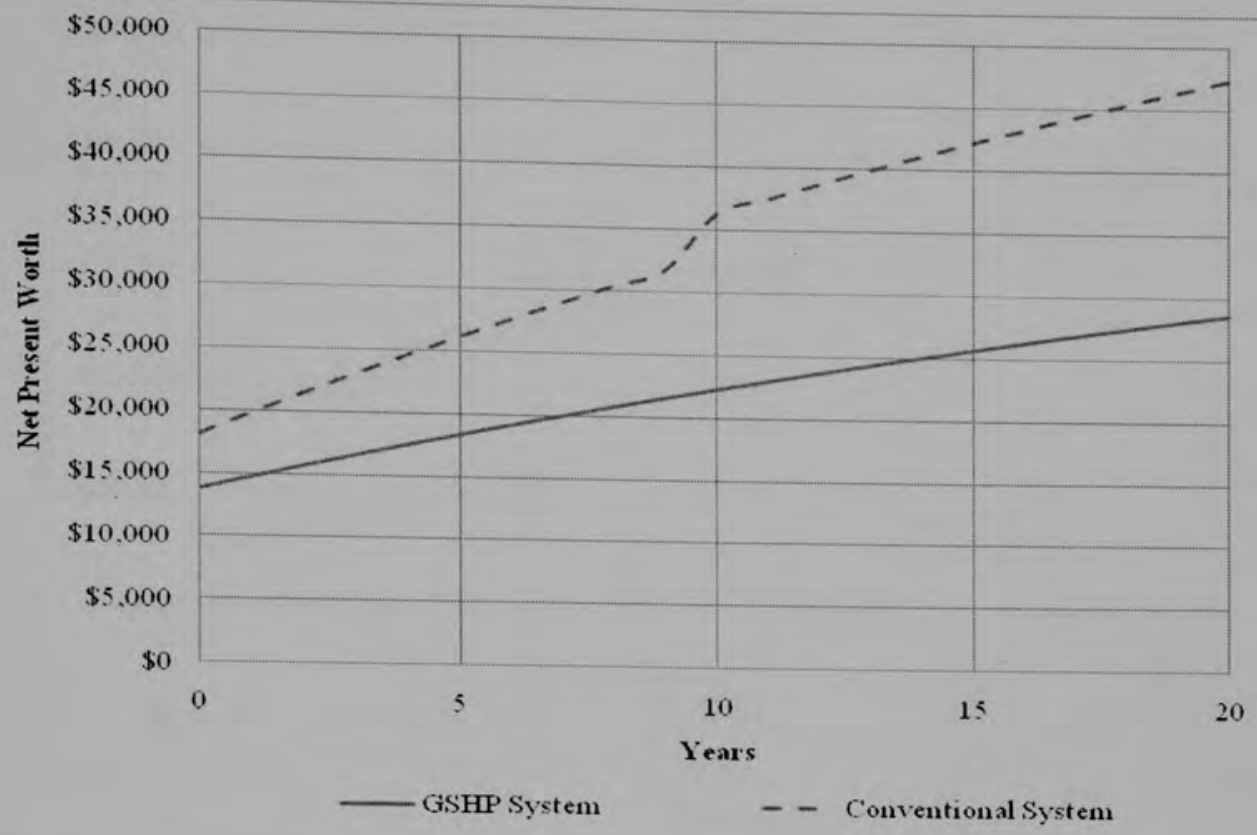

Figure 48 - Life-cycle cost calculations for residential unit 2 after incentives

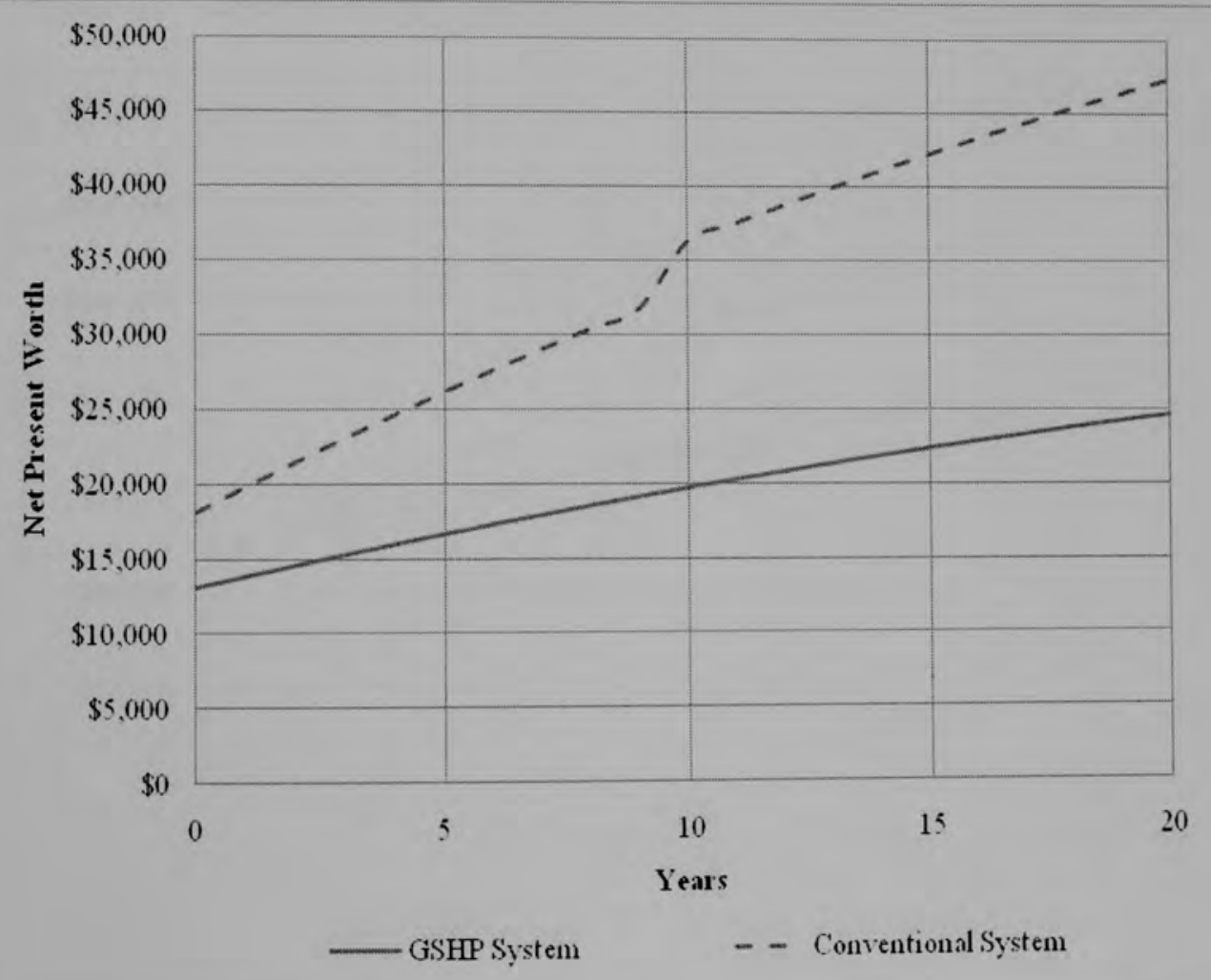

Figure 49 - Life-cycle cost calculations for residential unit 3 after incentives 


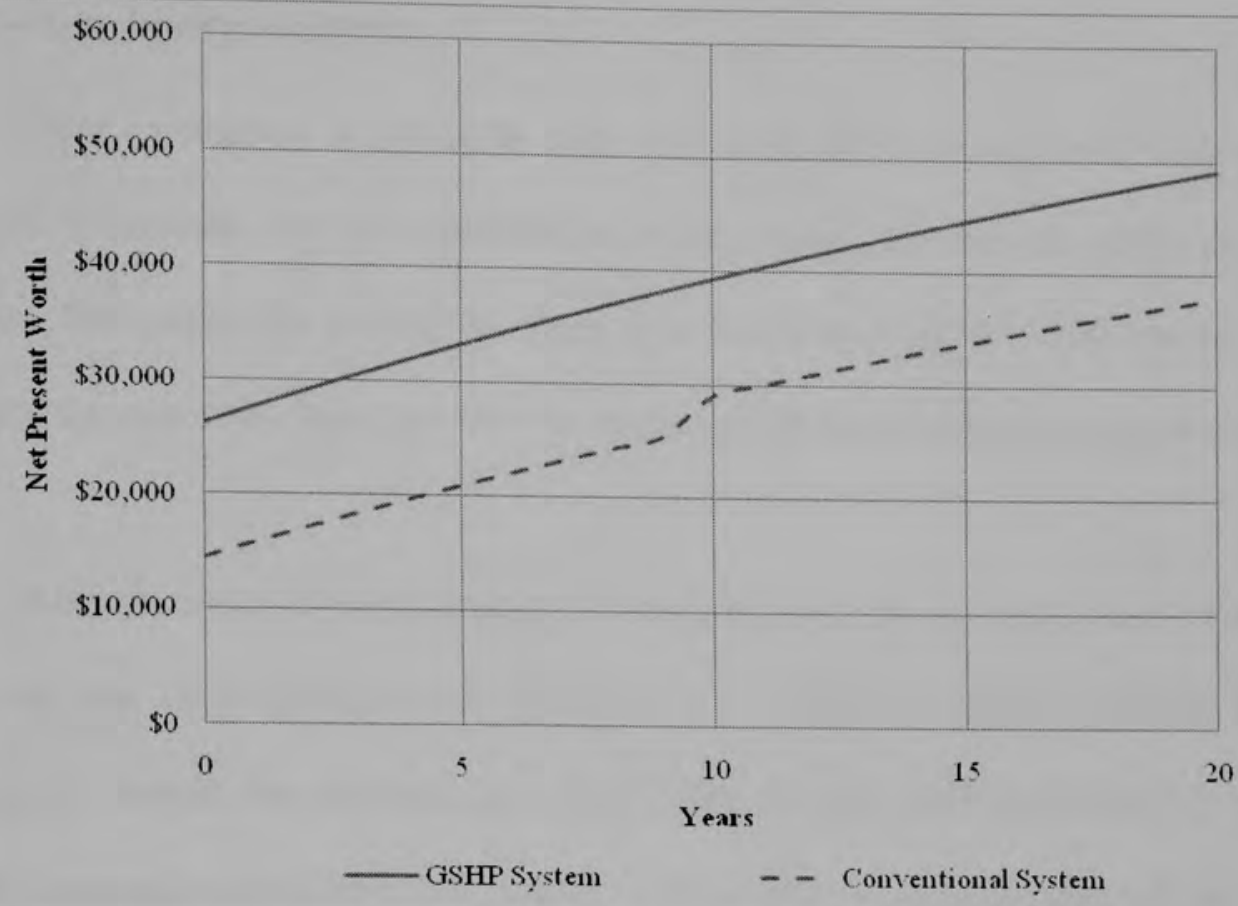

Figure 50 - Life-cycle cost calculations for residential unit 4 after incentives

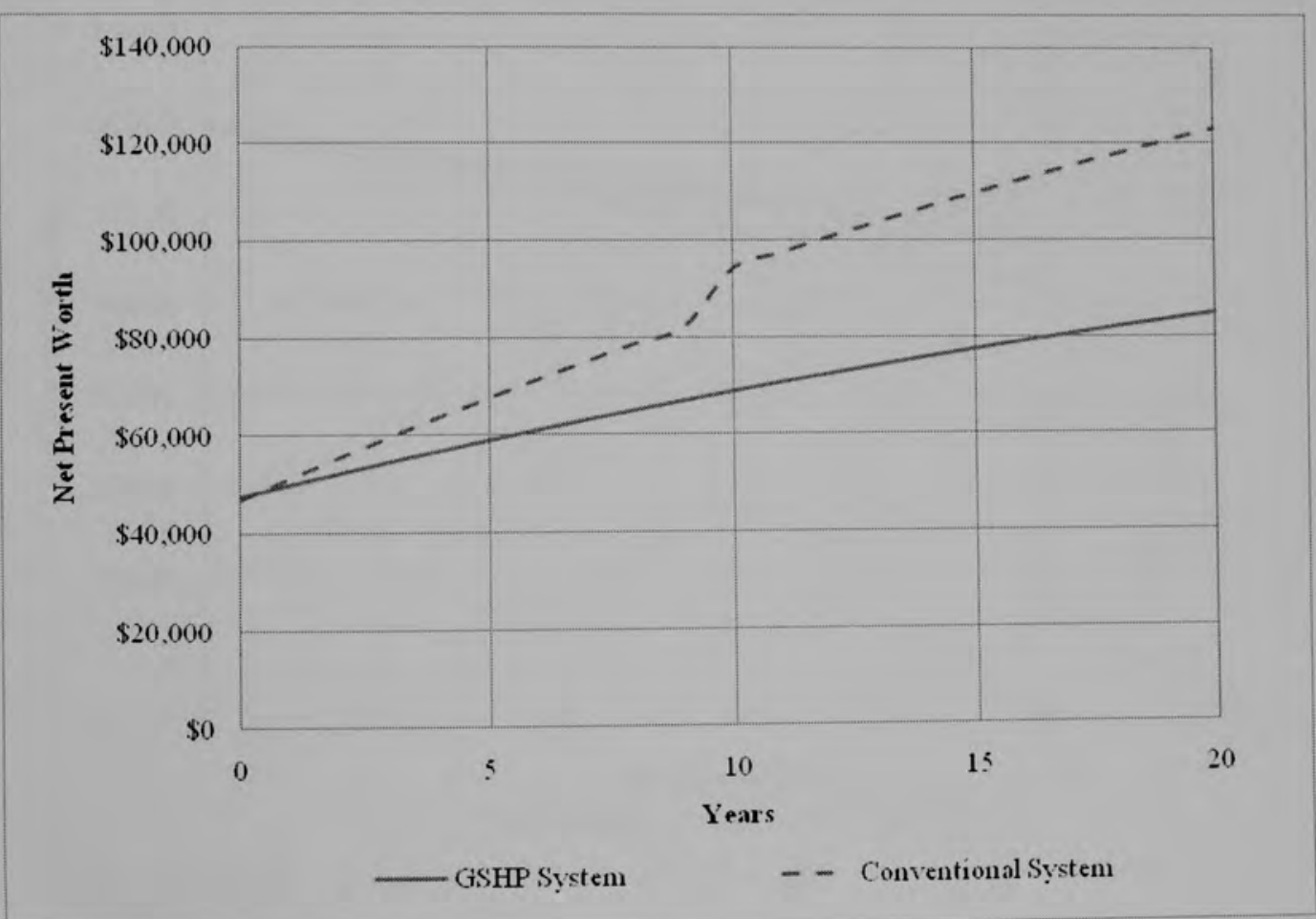

Figure 51 - Life-cycle cost calculations for Rodney Rich Building after incentives 


\subsection{2 - Sensitivity Analysis}

Upon calculation of life-cycle costs with most likely costs, a sensitivity analysis has been conducted. All the variables have been taken into account while doing the analysis. This sensitivity analysis has been done based on possible variations that can be triggered by economic situations. For the sensitivity analysis, residential unit 4 is taken as basis.

Also the effect of initial costs and electricity costs on the net present value of the life-cycle cost of the GSHP unit is presented in Figure 54. The sensitivity analysis calculation showed that payback period of GSHP systems are highly dependent on the capital costs and electricity costs. Among those, it is seen that the effect of initial costs are more apparent.

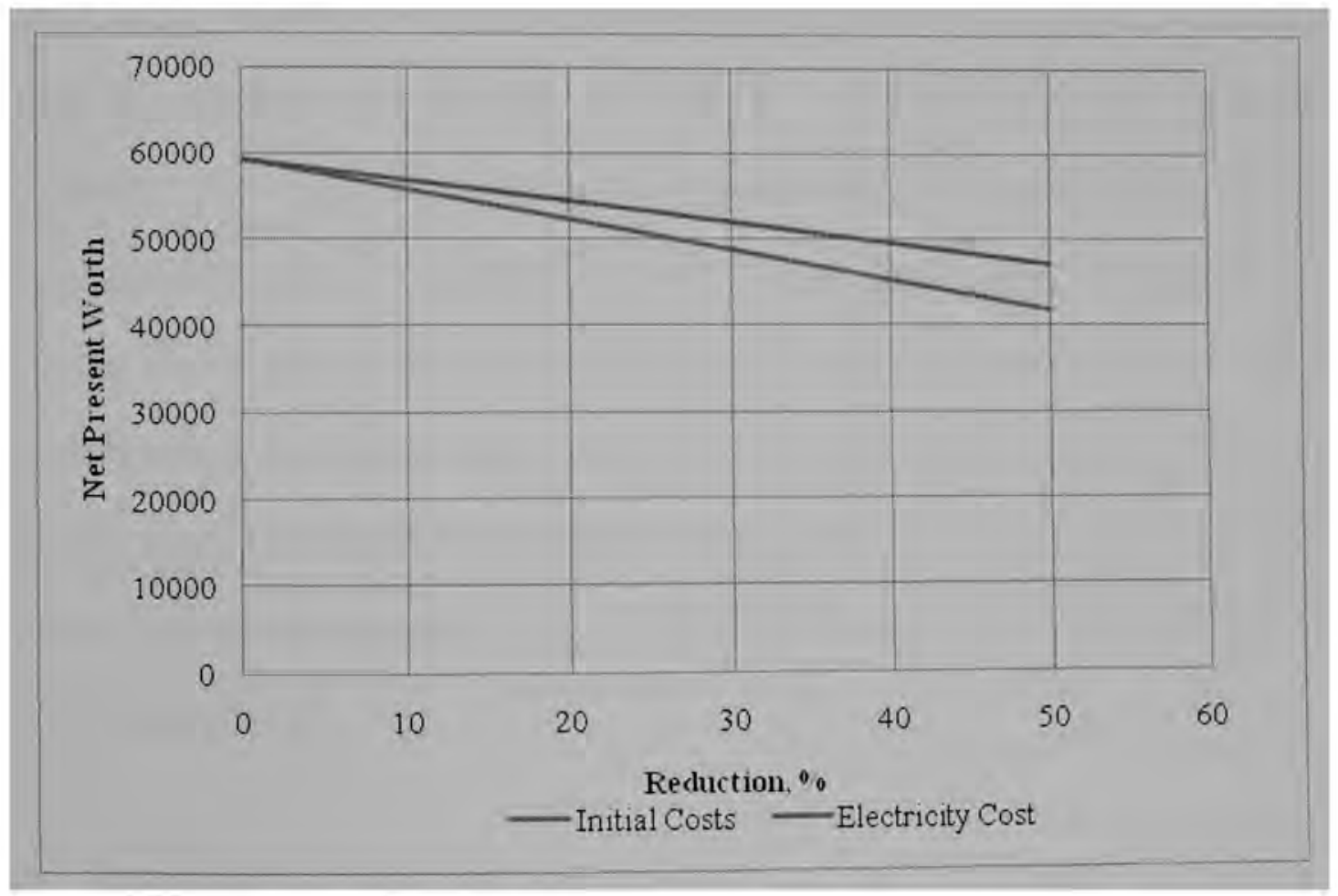

Figure 52 - The change in net present worth with respect to initial costs and electricity prices 


\section{5 - Conclusions}

Main goal of the study was to establish an easy-to-follow guideline for calculating the life-cycle costs of GSHP systems. This has been done through studying and listing all the cost items that can come up during the operational life of a GSHP system. The cost items have been explained and a map has been created for future users who'd like to compare a HVAC alternative with a GSHP system. A conventional HVAC alternative has been compared with GSHP alternative for this purpose and the life-cycles costs and payback periods were calculated using this relatively simple method.

Another aim of the study was to present the change in the life-cycle cost of a typical GSHP system as several variables used in life-cycle cost calculations fluctuate. These variables were those cost items that may change due to electricity costs, climatic conditions, initial costs and offered rebates or tax credits. The rate of change on the lifecycle cost with respect to different variables is the conducted sensitivity study. It was seen that the net present worth of all costs are most sensitive to electricity costs. Capital installation cost also had a considerable effect, but the effect of other cost items was minimal. It can be asserted that with the increasing trend in electricity costs, the GSHP systems will be more economical and will offer shorter payback periods compared to the conventional systems.

Also, several project data obtained from local GSHP contractors was presented and compared with existing information. Furthermore, experiences of professionals in the 
industry will be conveyed and possible ways of reducing costs and expanding the usage of GSHP systems will be discussed. It can be said that the GSHP systems will be used more in the future, however lack of regulations and enforcement of codes stand as a big barrier among these systems.

Overall, this study introduced a life-cycle cost estimation methodology for the GSHP systems and provided a comparison with a conventional HVAC system. It was seen that GSHP system is economically favorable. Also, in the sensitivity analysis, it was seen that the most important price component is the annual electricity costs, initial installation costs coming after that.

In future, the study may be extended to include possible variations in climatic and geographical conditions to achieve a broader spectrum. The model currently used can be highly computerized and supported with a stronger database to allow users to easily compare life-cycle costs of HVAC alternatives. 


\section{REFERENCES}

Bloomquist, R G. "The economics of geothermal heat pump systems for commercial and institutional buildings." Proceedings Conference on Geothermal Energy in Underground Mines, 2001.

Chiasson, A D. "Feasibility Study of a Geothermal Heat Pump System Lapwai MiddleHigh School, Lapwai, ID." Midwest Research Institute (Geo-Heat Center, Oregon Institute of Technology), 2006.

Chiasson, A D. "Life-Cycle Cost Study of a Geothermal Heat Pump System Bia Office Building, Winnebago, NE." Midwest Research Institute (Geo-Heat Center, Oregon Institute of Technology), 2006.

Chiasson, A D, C Yavuzturk, and W J Taibert. "Design of school building HVAC retrofit with hybrid geothermal heat pump system." Journal of Architectural Engineering 10 (2004): 103-111.

Engineering News and Record. http://www.enr.com.

Fredin, Paul W. "Ground Source Heat Pumps vs. Conventional HVAC: A comparision of Economic and Environmental Costs." Master's Thesis (Air Force Institute of Technology), 2009.

"Ground-Source Heat Pumps at Department of Defense Facilities." Report to Congress (Department of Defense), 2007.

Holihan, Peter. "Analysis of geothermal heat-pumps manufacturers survey data." US Energy Information Agency, Washington (DC), 1997.

Hughes, P J, and J A Shonder. "The Evaluation of a 4000-Home Geothermal Heat Pump." ORNL/CON-460 (Oak Ridge National Laboratory.), 1998.

Hughes, Patrick J. "Geothermal (Ground-Source) Heat Pumps: Market Status, Barriers to Adoption,." ORNL/TM-2008/232 (Oak Ridge National Laboratory), 2008.

Kavanaugh, S, S Gilbreath, and J Kilpatrick. "Cost containment for ground-source heat pumps." Final report submitted to the Alabama Universities-TVA research consortium (AUTRC) and the Tennessee Valley Authority (University of Alabama), 1995.

Lienau, Paul J. "Geothermal heat pumps performance and utility programs in the United States." Energy Sources 19 (1997): 1-8. 
Martin, M A, D J Durfee, and P J Hughes. "Comparing Maintenance Costs of Geothermal Heat Pump Systems with other HVAC Systems in Lincoln Public Schools: Repair, Service, and Corrective Actions." ASHRAE Annual Meeting 105 (1999).

Means. Assemblies Cost Data. Edited by 34th Annual Edition. Kingston, MA: R.S.
Means, 2009.

Means. Building Construction Cost Data. Edited by 34th Annual Edition. Kingston, MA: R.S. Means, 2009.

Means. Facilities Maintenance and Repair Cost Data. Edited by 34th Annual Edition. Kingston, MA: R.S. Means, 2009.

Moore, Alex. "Capital, Operating, and Maintenance Costs of GeoExchange and Conventional HVAC Systems." Princeton Economic Reserach Inc., 1999.

Trahan, Ronnie D. "Geothermal HVAC Systems - A Business Case Analysis for Net Zero Plus." Master's Thesis (NAVAL POSTGRADUATE SCHOOL), 2009.

U.S. Bureau of Labor Statistics. http://www.bls.gov.

U.S. Energy Information Administration Website. http://www.eia.doe.gov/. 


\section{APPENDIX}

A Sample Survey Prepared for Gathering Information for GSHP Systems

Please provide the engineering design cost $(\$)$

Please provide the construction management cost (if applicable), (\$).

Please provide drilling cost (for both of the wells), (\$)

Equipment Cost

Labor Cost

Total Cost

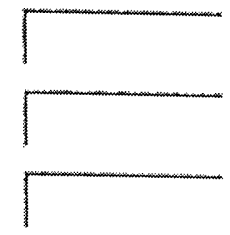

Please provide cost data regarding well casing (including both of the wells), (\$)

Equipment Cost

Material Cost

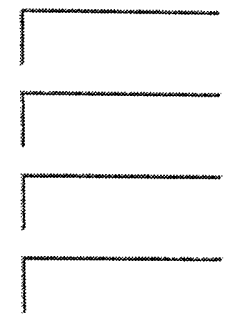

Total Cost

Please provide cost data regarding grouting of wells (including both of the wells), (\$)

Equipment Cost

Material Cost

Labor Cost

Total Cost

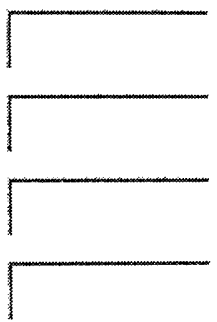

Please provide cost information regarding water pump, (\$).

Material Cost

Labor Cost

Total Cost

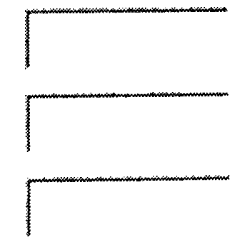

Please provide information regarding pump controls (if not included in water pump cost), (\$) 
Material Cost

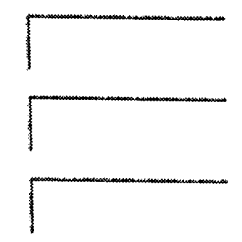

Total Cost

Please provide cost information regarding pipes (for pipes and fittings used underground in both wells), (\$).

Material Cost

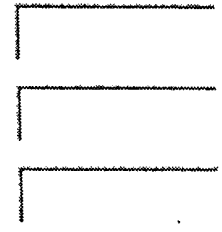

Total Cost

Provide cost information for heat pump, (\$).

Material Cost

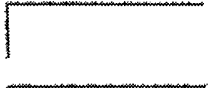

Labor Cost

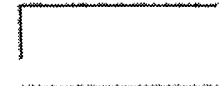

Total Cost

Please provide cost information regarding pipes and fittings (from wells to heat pump), (\$).

Material Cost

Labor Cost

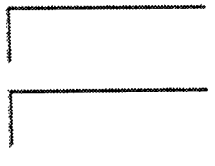

Total Cost 